Loyola University Chicago, School of Law

LAW eCommons

Faculty Publications \& Other Works

2020

The Omega Man or the Isolation of U.S. Antitrust Law

Spencer Weber Waller

Loyola University Chicago, School of Law, swalle1@luc.edu

Follow this and additional works at: https://lawecommons.luc.edu/facpubs

Part of the Antitrust and Trade Regulation Commons

Recommended Citation

Spencer Weber Waller, The Omega Man or the Isolation of U.S. Antitrust Law, 52 CONN. L. REV. 123 (2020).

This Article is brought to you for free and open access by LAW eCommons. It has been accepted for inclusion in Faculty Publications \& Other Works by an authorized administrator of LAW eCommons. For more information, please contact law-library@luc.edu. 


\section{CONNECTICUT \\ LAW REVIEW}

\begin{tabular}{llc}
\hline \hline VOLUME 52 & APRIL 2020 & NUMBER 1
\end{tabular}

\section{Article}

\section{The Omega Man or the Isolation of U.S. Antitrust Law}

\section{SPENCER WEBER WALLER}

There is a classic science fiction novel and film that present a metaphor for the isolation of United States antitrust law in the current global context. Richard Mathiesson's 1954 classic science fiction novel, I am Legend, and the later 1971 film released under the name of The Omega Man starring Charleton Heston, both deal with the fate of Robert Neville, a survivor of a world-wide pandemic who believes he is the last man on Earth.

While I am Legend and The Omega Man are obviously works of fantasy, it nonetheless has resonance for contemporary antitrust debate and discourse. United States antitrust law and policy diverges significantly from the rest of the global antitrust community in important areas of scope, philosophy, doctrine, procedure, remedies, and institutions. Much of this divergence in world view is the product of history and path dependence that is largely unique to the United States experience. At the same time, some of the divergence is the result of ideological choices over the past forty years that improbably have remained in place in the United States, while other politics, economics, values, and policy choices have come into prominence throughout the rest of the world.

Unlike The Omega Man, there is no plague and there are no monsters. But there are major fault lines in competition law and policy where the United States is the outlier and in danger of becoming The Omega Man. While there are also many issues of agreement where the United States has been a thought leader, there are a significant number of the most salient and controversial issues in modern competition law where the United States is choosing to go it alone or nearly so.

There are some important caveats to this tale of antitrust exceptionalism. Some of the United States antitrust exceptionalism means more enforcement than elsewhere in the world. In most of the areas discussed in this article, it means less enforcement that is seen elsewhere, particularly than in the European Union and the numerous jurisdictions whose competition law is modeled on EU principles. Nor does going it alone, or being in the minority, mean that the United States position necessarily is in error, but it does caution against demonizing foreign approaches or relentlessly searching to transplant U.S. approaches into very different societies. 
This Article surveys several significant areas of antitrust law and policy where United States law, procedure, institutions, and remedies differ significantly from the rest of the world. The basic thesis of the Article is that the growing isolation of U.S. antitrust law is more than just a transatlantic divide. Rather, much of the global community understands U.S. antitrust law and policy, but has rejected its current narrow form in favor of a broader vision of what competition law means, what legal rules are appropriate, and how they should be enforced. Even in areas such as mergers and cartels, outward convergence often masks critically different practices just beneath the surface.

As a result, the debate over the future of the Chicago School is largely moot. Examining what the rest of the world competition community actually does, rather what it says, shows the debate is largely over. Whether measured by numbers of jurisdiction, percentage of world gross domestic production, population, or most other measures, the Chicago school paradigm is the outlier, The Omega Man. 


\section{ARTICLE CONTENTS}

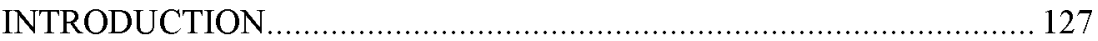

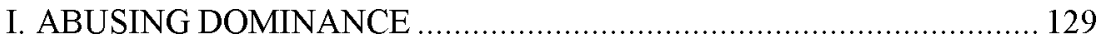

A. THE NARRow SCOPE AND INTERPRETATION OF SECTION 2 OF THE

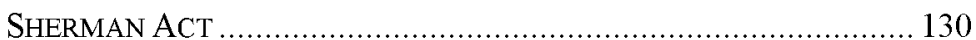

B. THRESHOLDS FOR DOMINANCE INTERNATIONALLY .................... 132

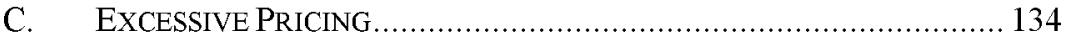

D. PRICE DISCRIMINATION ....................................................... 138

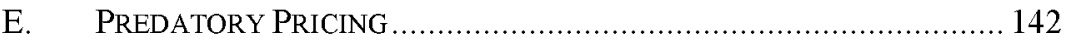

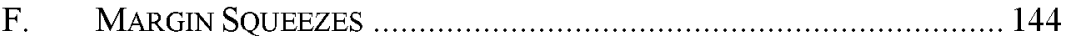

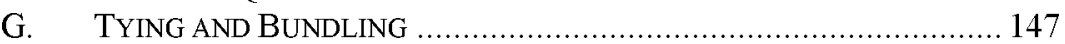

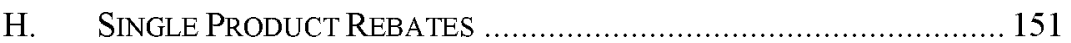

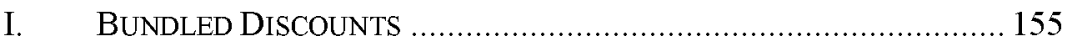

J. ESSENTIAL FACILITIES DOCTRINE AND REFUSALS to DEAL .......... 158

II. THE DOMAIN OF COMPETITION LAW ……............................... 165

A. Market STUdiES AND MARKet INVESTIGATIONS ......................... 165

B. Competition AND THE Public SECTOR ……............................. 169

C. State AidS AS Competition LAW ....................................... 170

D. PUBLIC INTEREST FACTORS .................................................. 172

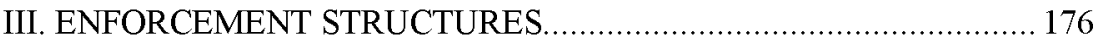

IV. REMEDIES AND PRIVATE ENFORCEMENT_............................... 181

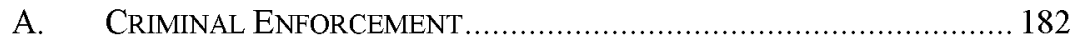

B. ADMINISTRATIVE AND CIVIL FINES ......................................... 184

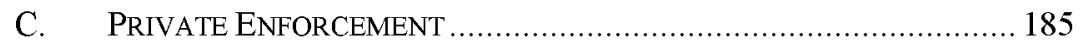

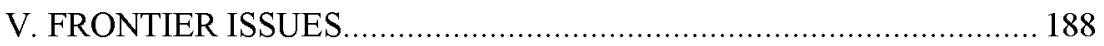

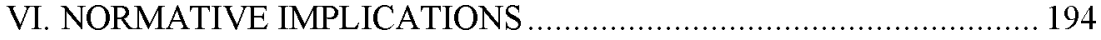

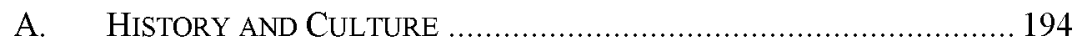

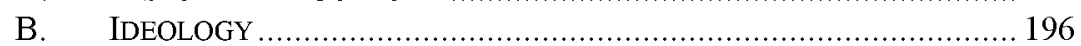

C. EXCLUSION FROM THE CONVERSATION ......................................... 203

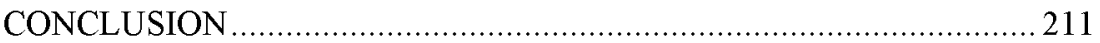




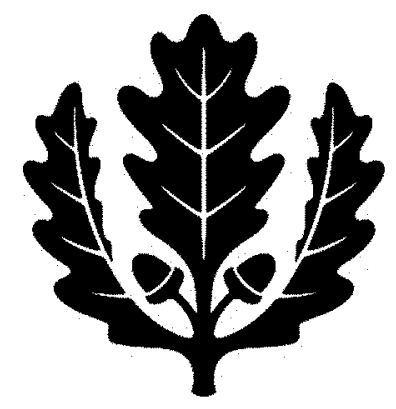




\title{
The Omega Man or the Isolation of U.S. Antitrust Law
}

\author{
SPENCER WEBER WALLER *
}

\section{INTRODUCTION}

There is a classic science fiction novel and film that presents a metaphor for the isolation of United States antitrust law in the current global context. Richard Matheson's 1954 classic science fiction novel I Am Legend, ${ }^{1}$ and the later 1971 film released under the name of The Omega Man starring Charlton Heston, ${ }^{2}$ both deal with the fate of Robert Neville, a survivor of a world-wide pandemic who believes he is the last man on Earth.

Humankind has been destroyed by a war and subsequent plague that resembles vampirism. Neville lives in post-apocalyptic Los Angeles in a heavily fortified house further protected by garlic, mirrors, and crucifixes. For years, he confronts only mindless vampires who seek his destruction. Neville defends himself from attacks during the night hours and uses the daytime to scavenge for supplies, kill vampires, and search for a cure to the plague.

He eventually discovers there are in fact rational survivors. Humans, infected by the plague, have been turned into a different type of vampire, largely allergic to daylight. They have formed a new nighttime society also seeking a cure or treatment for their condition. After a series of uneasy contacts and misunderstandings between Neville and members of the new society, Neville's home is attacked by members of the new society. In the ensuing struggle, Neville kills members of the group and is eventually captured.

\footnotetext{
* John Paul Stevens Chair in Competition Law, Loyola University Chicago School of Law. Thanks to Christopher Dempsey, Emily Eggmann, Krystyna Kudlata, and Frances Butler for their research assistance and to Amedeo Arena, Darren Bush, Ariel Ezrachi, James Gathii, Philip Marsden, Matthew Sag, Christopher Sagers, Maurice Stuke, as well as participants at workshops at Loyola University Chicago; Centre for Competition Law \& Policy, Oxford University; New Zealand Commerce Commission; and the U.K. Competition and Markets Authority for their comments and feedback.

${ }^{1}$ RICHARD MATHESON, I AM LEGEND (1954).

${ }^{2}$ THE OMEGA MAN (Walter Seltzer Productions 1972). The Omega Man was later remade in 2007 under the name $I$ Am Legend starring Will Smith, with important changes that make it both less interesting and less relevant as a metaphor to themes explored in this Article. I AM LEGEND (Warner Bros. 2007). Richard Matheson also wrote, under a pseudonym, the screenplay for a 1964 film version titled The Last Man on Earth. THE LAST MAN ON EARTH (Associated Producers Inc. 1964). There is an additional 2007 straight to video version entitled I AM OMEGA. I AM OMEGA (The Asylum 2007). The $1954 \mathrm{IAm}$ Legend novel also has been described as an inspiration for George Romero's classic zombie film Night of the Living Dead. John Casteele, George Romero Invented the Modern Zombie Horror Genre, SCREENRANT (July 22, 2017), https://screenrant.com/george-romero-death-tribute-zombies/.
} 
As he awaits execution, he realizes that civilization did not end, it just evolved in unexpected ways. While he originally viewed the new struggling civilization as monsters, they, in fact, viewed him the same way. Parents in the new civilization used him as a sort of boogey man to warn children who never knew any other world to avoid straying too far from home or into the daylight. Rather than a survivor of old humanity, he is now an evil legend to the new race born of the infection. As he spends his final moments, he realizes that he has become "a new superstition entering the unassailable fortress of forever. I am legend." ${ }^{\text {"3 }}$

While I Am Legend and The Omega Man are obviously works of fantasy, they nonetheless have resonance for contemporary antitrust debate and discourse. United States antitrust law and policy diverges significantly from the rest of the global antitrust community in important areas of scope, philosophy, doctrine, procedure, remedies, and institutions. Much of the divergence in worldview is the product of history and path dependence that is largely unique to the United States experience. At the same time, some of the divergence is the result of ideological choices over the past forty years that improbably have remained in place in the United States, while other politics, economics, values, and policy choices have come into prominence throughout the rest of the world.

Unlike in The Omega Man, there is no plague, ${ }^{4}$ and there are no monsters. But there are major fault lines in competition law and policy where the United States is the outlier and in danger of becoming The Omega Man. While there are also many issues of agreement where the United States has been a thought leader, there are a significant number of the most salient and controversial issues in modern competition law where the United States is choosing to go it alone or nearly so.

There are some important caveats to this tale of antitrust exceptionalism. Some of the United States antitrust exceptionalism means more enforcement than elsewhere in the world. In most of the areas discussed in this Article, it means less enforcement than is seen elsewhere, particularly than in the European Union and the numerous jurisdictions whose competition law is modeled on EU principles. Nor does going it alone, or being in the minority, mean that the United States' position is necessarily in error, but it does caution against demonizing foreign approaches or relentlessly searching to transplant U.S. approaches into the approaches of very different societies.

This Article surveys several significant areas of antitrust law and policy where United States law, procedure, institutions, and remedies differ

\footnotetext{
${ }^{3}$ MATHESON, supra note 1 , at 170.

${ }^{4}$ But see Spencer Weber Waller, The Law and Economics Virus, 31 CARDOzO L. REV. 367, 369 (2009) (using "the metaphor of the virus to capture the dynamics of how the Chicago School [analysis of antitust regulation] has spread by penetrating a new area of the law, replicating itself, and transmitting itself to new host bodies of law or legal jurisdictions").
} 
significantly from the rest of the world. The basic thesis of the Article is that the growing isolation of U.S. antitrust law is more than just a transatlantic divide. ${ }^{5}$ Rather, much of the global community understands U.S. antitrust law and policy, but has rejected its current narrow form in favor of a broader vision of what competition law means, what legal rules are appropriate, and how they should be enforced. Even in areas such as mergers and cartels, outward convergence often masks critically different practices just beneath the surface.

As a result, the debate over the future of the Chicago School is largely moot. Examining what the rest of the world competition community actually does, rather than what it says, shows the debate is largely over. Whether measured by number of jurisdictions, percentage of world gross domestic production, population, or most other measures, the Chicago School paradigm is the outlier, the Omega Man.

Part I examines single firm conduct as perhaps the most significant and largest area of substantive divergence between the United States and the rest of the world. Part II shifts to the scope of competition law where U.S. antitrust law simply does not capture a wide variety of conduct and tools that form the core competition law in much of the world. Part III looks at the widespread use of market studies and market investigations where the United States lacks the legal infrastructure to undertake what is routine in key jurisdictions around the globe. Part IV explores how competition law outside the United States may include public interest standards that fall outside the narrow focus of U.S. antitrust law and enforcement. Part V examines similar key divergences in public enforcement, remedies, and private enforcement. Part VI questions why the United States antitrust agencies have largely shied away from the implications of big data and algorithmic competition which are attracting more significant attention abroad. Part VII changes the focus from descriptive to normative and offers preliminary explanations as to the reasons for the growing isolation of United States antitrust law and how both the United States and the rest of the world can respond to this growing divide. I conclude by returning to the question of whether the United States is indeed the Omega Man of global competition law.

\section{ABUSING DOMINANCE}

One of the more significant areas of divergence between the rest of the world and the United States relates to the treatment of unilateral conduct that is harmful to competition. As a matter of terminology, the United States

\footnotetext{
${ }^{5}$ For a comparative analysis on antitrust law in the United States and abroad, see DANIEL J. GIFFORd \& ROBERT T. KUdRLE, The ATLANTIC Divide in ANTITRUST: AN EXAMination OF US AND EU COMPETITION POLICY (2015), and D. Daniel Sokol, Troubled Waters Between U.S. and European Antitrust, 115 MiCH. L. REV. 955, 955-97 (2017).
} 
refers to this area of antitrust law as monopolization while the EU and most of the rest of the world refers to this as abuse of dominance. Growing isolation of U.S. antitrust is particularly timely given the growing number of high profile EU and member state investigations and complaints against U.S. tech giants such as Microsoft, Google, Amazon, and Facebook where the United States took narrower, or no, enforcement action against them for the same behavior attacked in the EU and elsewhere.

\section{A. The Narrow Scope and Interpretation of Section 2 of the Sherman Act}

Part of the difference stems from the language and history of each system. The substantive language of section 2 of the Sherman Act remains unchanged since its adoption in 1890 and prohibits monopolization, attempted monopolization, and conspiracies to monopolize. ${ }^{6}$

While there is no single test for section 2 liability articulated by the United States Supreme Court, certain general principles have emerged. Liability for monopolization requires proof of both monopoly power and some conduct that tends to exclude competition on some basis other than competition on the merits.

Monopoly power has been defined as the power to raise prices or exclude competition. ${ }^{8}$ It can be proven through direct evidence of the ability to increase prices or that competition has in fact been excluded. ${ }^{9}$ Alternatively, monopoly power can be proven indirectly through the definition of a relevant market in which the defendant holds a substantial market share of a durable nature. ${ }^{10}$

Monopoly power is necessary, but not sufficient, to find a violation of section 2. The black letter law also requires proof of some conduct which tends to eliminate competition through some act which is either unlawful or

\footnotetext{
${ }^{6} 15$ U.S.C. $\$ 2$ (2012).

${ }^{7}$ United States v. Grinnell Corp., 384 U.S. 563, 570-71 (1966) ("The offense of monopoly under $\S 2$ of the Sherman Act has two elements: (1) the possession of monopoly power in the relevant market and (2) the willful acquisition or maintenance of that power as distinguished from growth or development as a consequence of a superior product, business acumen, or historic accident."); United States v. Aluminum Co. of Am., 148 F.2d 416, 429-32 (2d Cir. 1945) (holding that for there to exist a monopoly under section 2, there must be an intent to monopolize by the alleged harmful competitor).

${ }^{8}$ United States v. E.I. du Pont de Nemours \& Co., 351 U.S. 377, 391 (1956).

${ }^{9}$ FTC v. Ind. Fed'n of Dentists, 476 U.S. 447, 460-61 (1986).

${ }^{10}$ Eastman Kodak Co. v. Image Tech. Servs., Inc., 504 U.S. 451, 464 (1992) ("The existence of such power ordinarily is inferred from the seller's possession of a predominant share of the market." (internal citations omitted)); United States v. E.I. du Pont de Nemours \& Co., 353 U.S. 586, 593 (1957) ("Determination of the relevant market is a necessary predicate to a finding of a violation of the Clayton Act because the threatened monopoly must be one which will substantially lessen competition "within the area of effective competition."'). Cf. U.S. DEP'T. OF JUSTICE \& FED. TRADE COMM'N, HORIZONTAL $\begin{array}{lll}\text { MERGER GuIDELINES } & 7-11 & \text { (2010), }\end{array}$ https: $/ /$ www.justice.gov/sites/default/files/att/legacy/2010/08/19/hmg-2010.pdf (setting forth market definition tests for merger enforcement under section 7 of the Clayton Act).
} 
exclusionary. ${ }^{11}$ Examples of such conduct include behavior which lacks any legitimate or non-pretextual business justification; lacks economic sense except for its exclusionary effect; violates some other portion of the antitrust laws; or where the harm to competition substantially outweighs any proffered pro-competitive justification. ${ }^{12}$

The Supreme Court has described monopoly power in more positive terms in its 2004 Trinko opinion stating:

The mere possession of monopoly power, and the concomitant charging of monopoly prices, is not only not unlawful; it is an important element of the free-market system. The opportunity to charge monopoly prices-at least for a short period-is what attracts "business acumen" in the first place; it induces risk taking that produces innovation and economic growth. ${ }^{13}$

The EU approach to the abuse of a dominant position begins with the very different notion of a "special responsibility" of dominant firms to refrain from further diminishing competition. ${ }^{14}$ Although the precise scope and meaning of this special responsibility has been debated, and has evolved since the founding of EU competition in the 1950s, it continues to be reaffirmed in the recent decisions of the European Court of Justice and the European Commission. ${ }^{15}$ In addition, the EU has applied from time to time a concept of abuse of dominance "by object," akin to a per se violation of Article 102-something which is unknown in U.S. monopolization law. ${ }^{16}$

\footnotetext{
${ }^{11}$ United States v. Grinnell Corp., 384 U.S. 563, 576 (1966) (finding that defendants held a monopoly through unlawful and exclusionary practices).

${ }^{12}$ Verizon Commc'ns Inc. v. Law Offices of Curtis V. Trinko, 540 U.S. 398, 410 (2004) (holding that Verizon's insufficient assistance to its rivals is not a basis for an antitrust claim); Eastman Kodak Co. v. Image Tech. Servs., Inc., 504 U.S. 451, 482-86 (1992) (affirming summary judgment against the antitrust defendant because there were factual questions regarding the validity and sufficiency of each claimed justification); Aspen Skiing Co. v. Aspen Highlands Skiing Corp., 472 U.S. 585, 608-11 (1985) (affirming trial court's finding that ski company maintained unlawful monopoly in part because it failed to offer any business justification whatsoever for its pattern of conduct). See generally WILLIAM C. HOlmes \& MElissa H. MANGiaRAcina, ANTITRUST LAw HANDBOOK $§ 3: 5$ (2018-19 ed.) (collecting cases).

${ }^{13}$ Trinko, 540 U.S. at 407.

14 Case AT.39740, Google Search (Shopping), I 331 (2017), https://ec.europa.eu/competition/antitrust/cases/dec_docs/39740/39740_14996_3.pdf [hereinafter EU Google Search]; Case C-52/09, Konkurrensverket v. TeliaSonera Sveirge AB, 2011 E.C.R. I-527, 58283; Case C-202/07, France Télécom SA v. Comm’n, 2009 E.C.R. I-2369, 2391-92.

15 Case C-413/14, Intel Corp. v. Comm'n, ECLI:EU:C:2016:788, ๆ⿻ 60, 118, http: $/ /$ curia.europa.eu/juris/celex.jsf?celex $=62014 \mathrm{CC} 0413 \&$ lang $1=$ en\&type $=$ TXT\&ancre $=$.

${ }^{16}$ See generally Pablo Ibáñez Colomo, Beyond the 'More Economics-Based Approach': A Legal Perspective on Article 102 TFEU Case Law, 53 COMMON MKT. L. REV. 709, $713-14$ (2016); Nicolas Petit, From Formalism to Effects? - The Commission's Communication on Enforcement Priorities in Applying Article 82 EC, 32 WORLD COMPETITION L. \& ECON. REV. 485, 500 (2009); Louis Vogel, Une nouvelle venue sur la scène du droit de la concurrence: la restriction par objet, ConTRATs -
} 
This very different approach extends beyond the EU itself into the law of the twenty-eight member-states, the members of the European Free Trade Area, states that are bound to apply the principles of EU competition through preferential trade treaties, and those states which adopted similar provisions or interpretive principles into their own competition laws. As a result, there have been few takers for the U.S. cowboy-capitalism-deferential approach to the actions of dominant or monopoly firms. ${ }^{17}$

\section{B. Thresholds for Dominance Internationally}

The differences between the United States and the rest of the world begin almost at the inception of antitrust analysis involving conduct by powerful firms. As a rule of thumb in the United States, everything else being equal, a defendant with ninety percent or more of a well-defined market has monopoly power, a defendant with sixty-six percent or more may have such power, and a defendant with thirty-three percent would not. ${ }^{18}$

There is a separate provision of section 2 that also prohibits attempts to monopolize. Proof of unlawful monopolization requires a showing of specific intent, unlawful or exclusionary conduct, and a probability of success. ${ }^{19}$ This provision has rarely been used successfully in recent years as seen in the Microsoft litigation and various private cases seeking treble damages in diverse industries. ${ }^{20}$

Most competition regimes outside the United States operate on a very different set of premises. Most systems involve prohibitions on the abuse of an existing dominant position rather than conduct seeking to acquire such a position. As the European Commission in the Google Search case noted:

The concept of abuse is an objective concept relating to the behavior of an undertaking in a dominant position which is

CONCURRENCE - CONSOMMATION (Mai 2015) (Fr.) [Louis Vogel, A Newcomer to the Competition Law Scene: Restriction by Object, CONTS. - CONCURRENCE - CONSUMPTION (May 2015)].

${ }^{17}$ Anu Bradford et al., The Global Dominance of European Competition Law Over American Antitrust Law 16 J. EMP. LEGAL STUD. 731, 734 (2019) ("Our analyses reveal that the majority of jurisdictions with competition law regimes have laws that more closely resemble the European Union's competition laws than the United States' antitrust laws. Moreover, our detailed data allows us to trace the evolution of EU and US influence over time. This analysis reveals that the European model of competition became more emulated than United States' model in the 1990s, and the EU's 'sphere of influence' in the domain of competition regulation has continued to increase ever since.").

${ }^{18}$ United States v. Aluminum Co. of Am., 148 F.2d 416, 424 (2d Cir. 1945).

${ }^{19}$ Spectrum Sports, Inc. v. McQuillan, 506 U.S. 447, 456 (1993); Lorain Journal Co. v. United States, 342 U.S. 143, 153 (1951); Swift \& Co. v. United States, 196 U.S. 375, 396 (1905).

${ }^{20}$ In the past five years, there have been thirty-two private antitrust cases which have cited to attempted monopolization, but only a few with any in-depth discussion of an attempted monopolization claim. See e.g., Duty Free Ams., Inc. v. Estee Lauder Cos., 797 F.3d 1248, 1263-68 (11th Cir. 2015) (discussing, in the rare instance, the elements and requirements of an attempted monopolization claim); Gulf States Reorg. Grp., Inc. v. Nucor Corp., 721 F.3d 1281, 1285 (11th Cir. 2013) (articulating the elements a plaintiff must show to "establish a violation of $\S 2$ for attempted monopolization"). 
such as to influence the structure of a market where, as a result of the very presence of the undertaking in question, the degree of competition is weakened and which, through recourse to methods different from those which condition normal competition on the merits, has the effect of hindering the maintenance of the degree of competition still existing in the market or the growth of that competition. ${ }^{21}$

At the same time, the definition and thresholds for dominance differ significantly from the United States' approach to the finding of monopoly power. Dominance is defined as the ability to act independently from competition, consumers, or competitors. ${ }^{22}$ Very large market shares, absent exceptional circumstances, are in themselves usually evidence of dominance. $^{23} \mathrm{EU}$ and member-state cases have found a rebuttable presumption of dominance at fifty percent market share, ${ }^{24}$ with occasional cases finding dominance with market shares of as low as forty percent, depending on such factors as the size of the other firms in the market, entry barriers, and any countervailing buyer power. ${ }^{25}$

Outside the EU, a number of jurisdictions have similar presumptions of dominance based on market shares built into their laws, regulations, or guidelines. For example, China, Germany, South Africa, and Israel all have presumptions of market power or dominance in the range from thirty-five to fifty percent market share.$^{26}$ Other countries such as Canada have guidelines which generally require further investigation where market shares exceed fifty percent and have recognized the existence of market power where the market shares were as low as thirty-three percent. ${ }^{27}$

What emerges is a narrower set of firms subject to the strictures of section 2 than is the case for the rest of the world. This narrower U.S. lens

\footnotetext{
${ }^{21}$ EU Google Search, supra note 14, $\uparrow 333$.

${ }^{22}$ Id. ๆๆ 264-65; Case 85/76, Hoffman-La Roche \& Co. v. Comm'n, 3 CMLR 211 (1979), ๆ 38; United Brands v. Comm'n, Case 27/76, 1 CMLR 429 (1978), ๆ 62 [hereinafter United Brands].

${ }^{23}$ EU Google Search, supra note 14, - 266; Hoffman-La Roche, supra note 22, ๆ 41.

${ }^{24}$ EU Google Search, supra note 14, 1267 ; Case C-62/86, AKZO Chemie BV v. Commission, [1991] 5 C.M.L.R. 215, 960

${ }^{25}$ Virgin/British Airways, 2000 O.J. (L 30/1) 88; Antitrust procedures in abuse of dominance (Article 102 TFEU cases), EUR. COMMISSION, ANTITRUST, http://ec.europa.eu/competition/antitrust/procedures_102_en.html (last visited Nov. 25, 2019).

${ }^{26}$ Gesetz gegen Wettbewerbsbeschränkungen [GWB] [Act Against Restraints of Competition], June 26, 2013, Bundesgesetzblatt at 17502013 I, as amended by Article 1 of the law of June 1, 2017 (Ger.), https://www.gesetze-im-internet.de/englisch_gwb/englisch_gwb.html\#p0029; Anti-monopoly Law of the People's Republic of China (promulgated by the Standing Comm. Nat'l People's Cong., Aug. 30, 2007, effective Aug. 1, 2008), art. 19 (China), http:/www.npc.gov.cn/englishnpc/Law/200902/20/content_1471587.htm; Competition Act 89 of 1998 \$ (S. Afr.), http://www.compcom.co.za/wpcontent/uploads/2014/09/pocket-act-august-20141.pdf; Economic Competition Law, 5748-1988, Restrictive Trade Practices $§ 26$ (Isr.).

${ }^{27}$ Government of Canada, Abuse of Dominance - Enforcement Guidelines at 12 (Mar. 14, 2018) (draft for public consultation), http://www.competitionbureau.gc.ca/eic/site/cb-bc.nsf/eng/04345.html.
} 
for controlling the abuse of unilateral conduct also is reflected in the type of prohibited conduct itself.

\section{Excessive Pricing}

An important difference between section 2 and most competition law systems outside the United States lies in the treatment of high or excessive prices. While price increases may be evidence of the existence of monopoly power, these cannot be the basis for a finding of the unlawful or exclusionary conduct that is the second requirement for a section 2 violation.

One reason is textual. Section 2's prohibition of "monopolization" rather than "monopoly" requires something more than the possession of monopoly power. Modern courts have rejected older cases that hinted at the possibility of liability for no-fault monopolization. ${ }^{28}$ Section 2 thus requires some conduct that tends to exclude competition on some basis beyond superior skill, industry, and foresight. ${ }^{29}$

By definition, this does not include merely charging high or excessive prices. Everything else being equal, charging high prices (without more) tends to allow current competition to flourish and invite new entry rather than exclude existing forms of competition. In addition, on policy grounds, the Supreme Court in Trinko identified the possibility of monopoly profits as an important incentive and reward for new entry and innovative new forms of competition. ${ }^{30}$ This alone provides a profound source of divergence with international practice, where in many key jurisdictions the unilateral excessive pricing of dominant firms may be an abuse of a dominant position often specifically referenced in the express text of the competition law or regulation.

Article 102 of the Treaty on the Functioning of the European Union (TFEU) prohibits excessive prices as a form of abuse of dominance. Article 102 states in relevant part:

Any abuse by one or more undertakings of a dominant position within the internal market or in a substantial part of it shall be prohibited as incompatible with the internal market in so far as it may affect trade between Member States.

Such abuse may, in particular, consist in:

${ }^{28}$ See generally Milton Handler \& Richard M. Steuer, Attempts to Monopolize and No-Fault Monopolization, 129 U. PA. L. REV. 125 (1980) (discussing no-fault monopolization). United States v. Griffith, 334 U.S. 100 (1948), is one case that modern courts have rejected.

${ }^{29}$ United States v. Grinnell Corp., 384 U.S. 563, 570-71 (1966)

${ }^{30}$ Verizon Commc'ns Inc. v. Law Offices of Curtis V. Trinko, 540 U.S. 398, 407 (2004). 
(a) directly or indirectly imposing unfair purchase or selling prices or other unfair trading conditions .... 31

Excessive pricing cases have been part of the Article 102 jurisprudence since the earliest days of the EU. A price is found to be excessive where the price poses "no reasonable relation to the economic value of the product supplied. ${ }^{.32}$ In the seminal United Brands case, the European Court of Justice affirmed liability for excessive pricing as an unlawful abuse of dominance in circumstances where the dominant banana producer sold bananas in Germany, Denmark, the Netherlands, and the BelgoLuxembourg Economic Union in excess of the prices where it sold equivalent products in Ireland. ${ }^{33}$

United Brands is indicative of one line of excessive pricing cases in the EU. In such cases, the European Commission and the courts approach the case in the same manner as a price discrimination claim (also a violation of a different sub-part of Article 102) ${ }^{34}$ utilizing a comparison between time periods or comparable markets to determine whether prices are excessive. ${ }^{35}$

The more complex cases are so-called "pure" excessive pricing cases where there are no readily comparable time periods or other markets to compare prices with those of the dominant firm. Recently, in the United Kingdom, the Competition and Markets Authority (CMA) has challenged excessive pricing in the pharmaceutical industry in connection with sales to the National Health Service. ${ }^{36}$

The first such case was brought against Pfizer and Flynn Pharma for excessive pricing in the sale of anti-epilepsy medication. ${ }^{37}$ Pfizer had previously manufactured the drug in the United Kingdom, but later gave such rights to Flynn. Pfizer sold to Flynn at prices higher than historically usual, and then Flynn would resell again at a higher than usual price. The CMA, in finding that both Flynn and Pfizer had charged excessive pricing, looked to the "economic value" test outlined in United Brands and found prices to be excessive based on the excessive rate of return of both companies. ${ }^{38}$ The Competition Appeals Tribunal reversed and remanded the

\footnotetext{
${ }^{31}$ Consolidated Version of the Treaty on the Functioning of the European Union art. 102, May 9, 2009, 2008 O.J. (C 115) 01 [hereinafter TFEU].

${ }^{32}$ United Brands, supra note 22, ๆ 250.

${ }^{33} \mathrm{Id}$. ๆ $159-62$.

${ }^{34}$ TFEU art. 102.

${ }^{35}$ See infra notes $43-46$ and accompanying text.

${ }^{36}$ Margherita Colangelo \& Claudia Desogus, Antitrust Scrutiny of Excessive Prices in the Pharmaceutical Sector: A Comparative Study of the Italian and UK Experiences, 41 WORLD COMPETITION L. \& ECON. REV. 225, 225 (2018); Harry First, Excessive Drug Pricing as an Antitrust Violation, 82 ANTITRUST L.J. 701, 720-26 (2019).

${ }^{37}$ Case CE/9742-13, Unfair Pricing in Respect to the Supply of Phenytoin Sodium Capsules in the UK, Competition and Markets Authority (CMA) (Dec. 7, 2016)

${ }^{38} I d . \$ \$ 5.9,5.14$.
} 
CMA decision for further analysis and documentation of the excessive nature of the firms' pricing. ${ }^{39}$ Most recently, the CMA issued a preliminary decision finding Advanz Pharma liable for excessive pricing of liothyronine tablets. $^{40}$

The European Union subsequently announced their own investigation into Aspen Pharma for the excessive pricing of certain cancer drugs. ${ }^{41}$ The UK Competition Markets Authority also has opened investigations into excessive pricing in the manufacture of liothyronine tablets and hydrocortisone tablets. ${ }^{42}$

Excessive pricing claims exist outside the EU and its member states. Section 29a(b)(1) of the Israeli Antitrust Law states that a monopolist should not abuse their position, and that a monopolist shall be deemed to have abused its dominant position by establishing an unfair selling price. ${ }^{43}$ The 2017 guidelines put forth by the Israeli Antitrust Authority confirm that setting an unfair price will be considered an abuse of a monopoly position. ${ }^{44}$ The Israeli Guidelines allow the use of tests developed in other jurisdictions. $^{45}$ These tests can include price comparisons with past prices, prices charged by rivals for similar goods, and profit comparisons to other firms manufacturing similar products. ${ }^{46}$

Israeli litigation regarding excessive pricing began in 2011, with a case regarding the prices charged for cottage cheese. ${ }^{47}$ The case was certified as a class action in 2016 with the district court confirming that section $29 \mathrm{a}(\mathrm{b})(1)$ does in fact apply in cases of excessive pricing. ${ }^{48} \mathrm{~A}$ different

39 Flynn Pharma Ltd. v. Competition \& Mkts. Auth., [2018] CAT 11, http:/www.catribunal.org.uk/files/1275-1276_Flynn_Judgment_CAT_11_070618.pdf.

40 Carla Canivete, CMA Provisionally Finds Advanz Pharma Breached Competition Law, BLOOMBERG L. (June 30, 2019), https://news.bloomberglaw.com/mergers-and-antitrust/cmaprovisionally-finds-advanz-pharma-breached-competition-law-1.

41 European Commission Press Release IP/17/1323, Antitrust: Commission Opens Formal Investigation into Aspen Pharma's Pricing Practices for Cancer Medicines (May 15, 2017), https:/ec.europa.eu/commission/presscorner/detail/en/IP_17_1323.

${ }^{42}$ Press Release: Drug Company Accused of Abusing Its Position to Overcharge the NHS, GOV.UK (Nov. 21, 2017), https:/www.gov.uk/government/news/drug-company-accused-of-abusing-its-positionto-overcharge-the-nhs. A recent case in Spain found excessive pricing in the text messaging market, but that decision was overturned. Hettie O'Brien, Spanish Court Quashes Excessive Pricing Decision, GLOBAL COMP. REV. (Sept. 7, 2017), https:/globalcompetitionreview.com/article/1147175/spanishcourt-quashes-excessive-pricing-decision.

${ }^{43}$ Public Statement 1/17, The Antitrust Director General's Considerations in Enforcing the Prohibition Against Unfairly High Prices (28/02/17) The Antitrust Authority 23, https:/www.gov.il/en/Departments/legalInfo/opinionl 17.

${ }^{44} I d$.

${ }^{45} \mathrm{Id}$. at 17.

${ }^{46} \mathrm{Id}$.

47 Yossi Spiegel, Antitrust Enforcement of the Prohibition of Excessive Prices: The Israeli Experience, in EXCEssive PRICING AND COMPETITION LAW ENFORCEMENT 127, 132-33 (Yannis Katsoulacos \& Frédéric Jenny eds., 2018).

${ }^{48} \mathrm{Id}$. The case was scheduled for trial in the summer of 2018 . Id. at 133 . 
Israeli district court in 2017 also certified a class action excessive pricing suit against Dead Sea Works, a provider of potash. ${ }^{49}$ The Israeli Supreme Court passed on the opportunity to determine whether section $29 \mathrm{a}(\mathrm{b})(1)$ makes excessive pricing unlawful in a case brought against a governmentapproved monopoly in the production of natural gas. ${ }^{50}$ There have been nearly thirty such cases in Israel in a wide range of food and consumer products. $^{51}$

South Africa has taken an approach to excessive pricing that blends aspects of both the comparison and pure approaches. Section 8(a) of the South African Competition Act of 1998 prohibits a dominant firm from charging excessive price to the detriment of consumers or customers. ${ }^{52}$ In Competition Commission of South Africa v. Sasol Chemical Industries Limited, the Competition Tribunal of South Africa confirmed that section 8(a) claims include the factual determination of the actual price alleged to be excessive, the economic value of the good or service, and lastly include the exercise of a value judgment as to the difference between the actual price and economic value and whether this difference is excessive to the detriment of consumers. ${ }^{53}$ The Commission also laid out three tests it would use to determine whether or not a price is excessive: the price-cost test (comparing the price of the good and the cost of production), the export price comparison (comparing the price charged of the good in the country versus others), and the geographic markets test (looking at what the firm charges in other markets). ${ }^{54}$

The Competition Appeal Court of South Africa decided an excessive pricing case in 2009 involving a dominant steel firm. ${ }^{55}$ The court clarified that the analysis for excessive pricing in South Africa included two tests: the economic value test examining the cost of production versus the price of the good, and the reasonableness of the price in relation to the difference between price and cost. ${ }^{56}$

In 2017, the South African Competition Commission announced that it would conduct excessive price investigations into numerous pharmaceutical

\footnotetext{
${ }^{49}$ Id. at $133-34$.

${ }^{50} \mathrm{Id}$. at 135.

${ }^{51}$ Michal S. Gal, The Case for Limiting Private Litigation of Excessive Prices, J. COMPETITION L. \& ECON. at 18 (forthcoming 2020), https://papers.ssm.com/sol3/papers.cfm?abstract_id=3463386.

${ }^{52}$ Competition Act 89 of 1998 \& (a) (S. Afr.).

${ }^{53}$ Competition Comm'n of S. Afr. v. Sasol Chem. Indus. Ltd.,2014 1 (Tribunal) at 13 para. 56, 3132 para.119-22 (S. Afr.)

${ }^{54} \mathrm{Id}$. at 32,33 para. 130 . South Africa also has acted against excessive pricing in the telecom sector. Renee Bonorchis, Vodacom Says Reviewing S. Africa Competition Report on Pricing, BloOMBERG L. (Apr. 29, 2019), https://news.bloomberglaw.com/mergers-and-antitrust/vodacom-says-reviewing-safrica-competition-report-on-pricing.

${ }^{55}$ Mittal Steel S. Afr. Ltd. v. Harmony Gold Mining Co. Ltd. 20091 (CAC) at 1 (S. Afr.)

${ }^{56} I d$. at 45 para. 43.
} 
companies. ${ }^{57}$ Among those being investigated are Roche Holding AG for their provision of breast cancer medication, Pfizer for lung cancer medication, and Aspen for cancer medications. ${ }^{58}$

Excessive or unfair pricing also is prohibited by section 17(1) of the Anti-Monopoly Law of the People's Republic of China (PRC) ${ }^{59}$ In 2013, two companies in the river sand industry were found to have unfairly high prices based on a comparison of prices and costs as well as a comparison of prices with other river sand markets. ${ }^{60}$ Most recently, the PRC agency enforcing this provision found Qualcomm liable for excessive pricing of certain intellectual property licenses and certain tying violations, with the case eventually settling with a fine of $\$ 975$ million. ${ }^{61}$

The point is not whether these cases are well founded on the law or the facts. Rather, it is to illustrate the first of numerous aspects of cases of unilateral conduct outside the United States that proceed on theories which the United States has rejected.

\section{Price Discrimination}

The forgotten stepchild of U.S. antitrust law is the Robinson-Patman Act which bars various forms of price discrimination. The Act's principal provision forbids persons engaged in commerce:

[T]o discriminate in price between different purchasers of commodities of like grade and quality ... where the effect of

\footnotetext{
57 International Pharmaceutical Companies Investigated for Cancer Medicine Prices, COMPETITION COMM'N S. AFR. (June 13, 2017), http:/www.compcom.co.za/wpcontent/uploads/2017/01/International-pharmaceutical-companies-investigated-for-cancer-medicineprices.pdf.

${ }^{58} \mathrm{Id}$.

${ }^{59}$ Anti-Monopoly Law of the People 's Republic of China, Presidential Order No. 68, ICAO (Aug. 30, 2007, 6:32 PM), https:/www.icao.int/sustainability/Documents/Compendium_FairCompetition/ China/Anti-monopoly-Law_China.pdf; see also David S. Evans et al., Assessing Unfair Pricing Under China's Anti-Monopoly Law for Innovation-Intensive Industries 2 (Coase-Sandor Inst. for Law \& Econ., Working Paper No. 678, 2014), https://chicagounbound.uchicago.edu/cgi/viewcontent.cgi?referer=https: //duckduckgo.com/\&httpsredir=1\&article=1668\&context=law_and_economics ("Article 17(1) of China's Anti-Monopoly Law (AML) prohibits dominant firms from "selling commodities at unfairly high prices or buying commodities at unfairly low prices." (internal citation omitted)).

${ }^{60}$ Adrian Emch et al., NDRC's Antitrust Crackdown Continues and Its Scope Broadens, LEXOLOGY (Sept. 17, 2013), https://www.lexology.com/library/detail.aspx?g=51109180-f406-48b1-9710d6acaeblf413.

${ }^{61}$ See Stephen Harris, Jr., An Overview of the NDRC Decision in the Qualcomm Investigation, CPI 2 ANTITRUST CHRON. (July 2015) (summarizing the Qualcomm decision). For discussion of the AntiMonopoly Law and Qualcomm's liability, see Minkang, Anti-Abuse of Intellectual Property Rights Under the Anti-Monopoly Law: China's Approaches, 10 FronTIERS L. ChINA 488, 489 (2015), and Joe Zhang, China's Antitrust Crackdown Hits Qualcomm with US\$975 Million Fine: What Can Other Host States Learn From the Story?, InT'L Inst. Sustainable DeV. INV. TREATy News (May 21, 2015), https:/www.iisd.org/itn/2015/05/21/chinas-antitrust-crackdown-hits-qualcomm-with-us 975 -millionfine-what-can-other-host-states-learn-from-the-story/.
} 
such discrimination may be substantially to lessen competition or tend to create a monopoly in any line of commerce, or to injure, destroy, or prevent competition with any person who either grants or knowingly receives the benefit of such discrimination. ${ }^{62}$

The Act provides certain limited defenses for cost-justified discounts and for meeting competition, ${ }^{63}$ and also contains anti-circumvention provisions. ${ }^{64}$ There is even a criminal provision barring knowing violations of the Act for the purpose of "destroying competition, or eliminating a competitor." $\$ 55$

Despite decades of vigorous enforcement and expansive interpretation by the U.S. Supreme Court, ${ }^{66}$ the Robinson-Patman Act largely has become a dead letter. Neither the Federal Trade Commission nor the Justice Department have enforced the civil or criminal provisions in decades. Private civil enforcement has waned with the courts interpreting the language of the Act largely the same as the more restrictive provisions of the Sherman Act and imposing a variety of technical hurdles. ${ }^{67}$ Numerous critics have called for the abolition of some or all of the Robinson-Patman Act as against competitive norms and incompatible with the general tenor of the antitrust laws. ${ }^{68}$

In contrast, price discrimination remains part of the competition tool kit outside the United States, particularly as a form of abuse of dominance. As previously discussed, Article 102 of the Treaty on the Functioning of the European Union states that any abuse by a firm with a dominant position

\footnotetext{
${ }^{62} 15$ U.S.C. $\S 13$ (a) (2012).

${ }^{63} \mathrm{Id}$. $\$ 13(\mathrm{~b})$

${ }^{64} \mathrm{Id} . \S 13(\mathrm{c})-(\mathrm{e})$

${ }^{65} I d . \S 13 \mathrm{a}$

${ }^{66}$ See, e.g., Utah Pie Co. v. Cont'l Baking Co., 386 U.S. 685, 702-03 (1967); FTC v. AnheuserBusch, Inc., 363 U.S. 536, 542-45 (1960).

${ }^{67}$ See Volvo Trucks N. Am., Inc. v. Reeder-Simco GMC, Inc., 546 U.S. 164, 166 (2006) (indicating that the Robinson-Patman Act "proscribes only price discrimination [that] threatens to injure competition" (alteration in original) (citation and internal quotation marks omitted)); Brooke Grp. Ltd. v. Brown \& Williamson Tobacco Corp., 509 U.S. 209, 209-10 (1993) (comparing the "character" of claims under the two laws). See generally I ANTITRUST LAW DEVELOPMENTS 504-20 (7th ed. 2012) (collecting cases).

${ }^{68}$ See ANTITRUST MODERNIZATION COMM'N, REPORT AND RECOMMENDATIONS ch. IV.A (2007), https://govinfo.library.unt.edu/amc/report_recommendation/chapter4.pdf (recommending repeal); GIFFORD \& KUDRLE, supra note 5, at 63-73; Andrew I. Gavil, Secondary Line Price Discrimination and the Fate of Morton Salt: To Save it, Let It Go, 48 EMORY L.J. 1057, 1063 (1999) (advocating for "further refine[ment]" of the "injury to a competitor" concept); Earl W. Kintner \& Joseph P. Bauer, The RobinsonPatman Act: A Look Backwards, a View Forward, 31 ANTITRUsT BulL. 571,574 (1986) (summarizing literature and proposals for reform); John B. Kirkwood, Reforming the Robinson-Patman Act to Serve Consumers and Control Powerful Buyers, 60 ANTITRUst BulL. 358, 358 (2015) (discussing the flaws in the Robinson-Patman Act and advocating for reform); D. Daniel Sokol, Analyzing Robinson-Patman, 83 GEO. WASH. L. REV. 2064, 2065-66 (2015) (critiquing Robinson-Patman Act as contrary to consumer welfare).
} 
will be prohibited. ${ }^{69}$ Part 102 (c) of the Treaty specifically lists one example of such an abuse as "applying dissimilar conditions to equivalent transactions with other trading parties, thereby placing them at a competitive disadvantage.".70

This provision can apply to price discrimination claims as well as the tying, bundling, and excessive pricing claims discussed elsewhere in this Article. ${ }^{71}$ Three conditions must be present for a finding of unlawful price discrimination under EU law: (1) the firm imposing the differential pricing must have market power, (2) the firm has some ability to sort customers based on their willingness to pay, and (3) the firm must be able to prevent or limit the resale of the goods or services. ${ }^{72}$

In the EU, both primary line discriminatory practices and secondary line practices are regulated under Article 102(c). ${ }^{73}$ Primary line discriminatory practices include those that are aimed to hurt other competitors and include the offering of rebates, selective price cuts, and tying/bundling. ${ }^{74}$ Within the rebate setting, rebates given based on the quantity ordered were found to be discriminatory in Michelin $I I{ }^{75}$ fidelity rebates given to entice purchasers were found to be discriminatory in the Hoffman-La Roche case, ${ }^{76}$ and target rebates set on the retailer meeting a high sales target were also found to be discriminatory in Michelin I. ${ }^{77}$ In Irish Sugar, the Commission held that selective price cuts given to certain retailers by manufacturers can amount to price discrimination in violation of $102(\mathrm{c}){ }^{78}$

Secondary line price discrimination, whereby favored customers receive discounts or other forms of lower prices versus other customers, is also regulated under Article 102(c) ${ }^{79}$ For example, in the Brussels National Airport case, the Commission determined that Article 82(c) (the predecessor to Article 102(c)) applies to cases where a firm with a dominant position gives preference to one "undertaking" pursuing the same policy as another

\footnotetext{
${ }^{69}$ TFEU art. 102

${ }^{70} \mathrm{Id}$.

${ }^{71}$ See infra notes $120-75$ and accompanying text.

${ }^{72}$ Damien Geradin \& Nicolas Petit, Price Discrimination Under EC Competition Law: The Need for a Case-by-Case Approach 4 (Glob. Competition Law Ctr., Working Paper 07/05, 2005), https:/Www.coleurope.eu/research-paper/price-discrimination-under-ec-competition-law-need-casecase-approach.

${ }^{73} \mathrm{Id}$. at $10,26$.

${ }^{74} \mathrm{Id}$. at 11 .

${ }^{75}$ Case T-203/01, Michelin v. Comm'n, 2003 E.C.R. II-4071; Geradin \& Petit, supra note 72, at 12 .

${ }^{76}$ Case 85/76, Hoffman-La Roche \& Co. AG v. Comm'n, 1979 E.C.R. 461; Geradin \& Petit, supra note 72 , at 12 .

${ }^{77}$ Case 322/81, Michelin v. Comm'n, 1983 E.C.R. 3461; Geradin \& Petit, supra note 72, at 14

${ }^{78}$ Commission Decision 97/624, Irish Sugar, 1997 O.J. (L 258) 1; Geradin \& Petit, supra note 72 , at 16 .

${ }^{79}$ Geradin \& Petit, supra note 72 , at 26-27.
} 
"undertaking." ${ }^{" 80}$ Most recently, the European Court of Judgment stated that unlawful secondary line price discrimination does not require proof of "an actual, quantifiable deterioration in the competitive position." $" 81$

Russian antimonopoly law prohibits setting different prices for the same good and prohibits imposing discriminatory conditions for the sale of goods. ${ }^{82}$ The Federal Antimonopoly Service (FAS) of Russia implements a rule of reason approach when considering price discrimination cases. ${ }^{83}$ This approach considers the applicable market and the firm's power in that market, considers the motives behind the behavior, and finally weighs the positive effects on the policy against the negative effects. ${ }^{84}$ A Russian plaintiff in a price discrimination case must prove: (1) that different prices were set for the same product, (2) at the same time, (3) in the same market, and (4) there was no procompetitive justification for the setting of such prices. ${ }^{85}$ When looking to discriminatory condition cases, the FAS analyzes the dominant position of the firm, the effect of the policy, and any proffered justifications. $^{86}$

Section 47 of the Singapore Competition Act states that any act constituting an abuse of a dominant position will be prohibited ${ }^{87}$ The Act gives an example of such an abuse as "applying dissimilar conditions to equivalent transactions with other trading parties, thereby placing them at a competitive disadvantage. ${ }^{188}$ The Competition Commission of Singapore notes that such discrimination is only possible where the firm is able to differentiate between categories of buyers. ${ }^{89}$ Further, in order for the practice to be condemned, there must be evidence of actual harm to competition. ${ }^{90}$ Procompetitive justifications will also be considered when determining if price discrimination is an abuse. ${ }^{91}$ Such justifications can include efficient

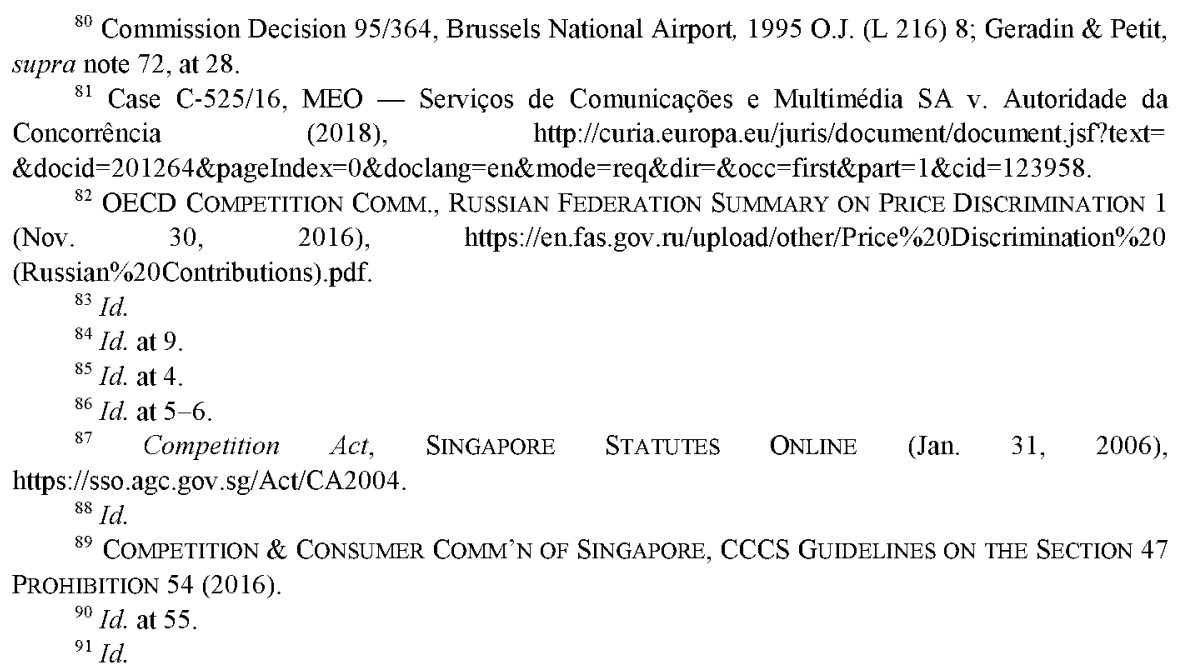

${ }^{80}$ Commission Decision 95/364, Brussels National Airport, 1995 O.J. (L 216) 8; Geradin \& Petit, supra note 72 , at 28 .

${ }^{81}$ Case C-525/16, MEO - Serviços de Comunicações e Multimédia SA v. Autoridade da Concorrência (2018), http://curia.europa.eu/juris/document/document.jsf?text= $\&$ docid $=201264 \&$ pageIndex $=0 \&$ doclang $=e n \&$ mode $=$ req $\&$ dir $=\& o c c=$ first $\&$ part $=1 \&$ cid $=123958$.

${ }^{82}$ OECD COMPETITION COMM., RUSSIAN FEDERATION SUMMARY ON PRICE DisCRIMINATION 1 (Nov. 30, 2016), https://en.fas.gov.ru/upload/other/Price\%20Discrimination\%20 (Russian\%20Contributions).pdf.

${ }^{83} \mathrm{Id}$.

${ }^{84} \mathrm{Id}$. at 9 .

${ }^{85} \mathrm{Id}$. at 4 .

${ }^{86} \mathrm{Id}$. at $5-6$.

87 Competition Act, Singapore StatuTtes ONLINE (Jan. 31, 2006), https://sso.agc.gov.sg/Act/CA2004.

${ }^{88} \mathrm{Id}$.

${ }^{89}$ COMPETITION \& CONSUMER COMM'N OF Singapore, CCCS Guidelines On THE SeCtion 47 PROHIBITION 54 (2016).

${ }^{90} \mathrm{Id}$. at 55

${ }^{91} \mathrm{Id}$. 
cost recovery, expansion of demand/opening up new markets, and various other efficiencies. ${ }^{92}$

Article 6 of Peru's Competition Act prohibits "restrictive practices that affect free competition." ${ }^{.93}$ Price discrimination is one example of vertical practices that restrict such competition. ${ }^{94}$ The law in Peru also considers price discrimination to be an abuse of dominance. ${ }^{95}$ In such abuse of dominance cases, there must be a showing of dominance and the defendant can proffer justifications for their price discrimination. ${ }^{96}$

The question again is not the soundness of the application of this area of the law. Price discrimination is yet another area that illustrates the divergence between widespread use of such provisions around the world but not in the United States, which has rejected this area of the law as a meaningful part of the antitrust enterprise.

\section{E. Predatory Pricing}

Predatory pricing is defined as the temporary cutting of price below some measure of cost to eliminate or discipline one or more competitors. ${ }^{97}$ Predatory pricing is virtually a dead letter in the United States despite being alive and well in many other jurisdictions, particularly those following an EU style abuse of dominance model. After decades of differing standards in the lower courts, the Supreme Court established in 1993 a daunting standard for predatory pricing in the Brooke Group case. ${ }^{98}$ The Court held that to establish a claim for unlawful predatory pricing the plaintiff must show both that the defendant's prices fell below some economically relevant measure of cost and that the defendant was likely to recoup any losses suffered during the period of predation. ${ }^{99}$ In the aftermath of Brooke Group, there are no reported verdicts in favor of either the government or private plaintiffs in U.S. predatory pricing cases. ${ }^{100}$

\footnotetext{
${ }^{92} \mathrm{Id}$.

${ }^{93}$ ORG. For ECON. Co-OPERATION [OECD], Peru-PeER REVIEW OF COMPETITION LAW AND POLICY 25 (2004), http://www.oecd.org/countries/peru/34728182.pdf.

${ }^{94} \mathrm{Id}$.

${ }^{95}$ Id. at 29 .

${ }^{96} \mathrm{Id}$.

${ }^{97}$ Predatory pricing can arise under both the monopolization and attempted monopolization prongs of section 2 of the Sherman Act as well as section 2A of the Clayton Act's price discrimination provisions.

${ }^{98}$ Brooke Grp. Ltd. v. Brown \& Williamson Tobacco Corp., 509 U.S. 209 (1993)

${ }^{99} \mathrm{Id}$. at 222, 224; see also Weyerhaeuser Co. v. Ross-Simmons Hardwood Lumber Co., 549 U.S. 312, 325 (2007) (applying Brooke Group to allegations of predatory buying).

${ }^{100}$ See, e.g., United States v. AMR Corp., 335 F.3d 1109, 1114 (10th Cir. 2003) (quoting the Supreme Court, which noted "there is a consensus among commentators that predatory pricing schemes are rarely tried, and even more rarely successful").
} 
In contrast, the seminal case establishing the test for predatory pricing in the EU is Akzo Chemie BVv. Commission. ${ }^{101}$ Akzo establishes that prices set below average variable cost (AVC) will be deemed a per se violation. ${ }^{102}$ However, where a firm sets prices above AVC but below average total cost (ATC), a violation will only be found where it is established that the price was set as a plan to eliminate a competitor. ${ }^{103}$ Later, in France Télécom $v$. Commission and Tetra Pak, the Commission established that recoupment is not an element of predatory pricing cases in the European Union. ${ }^{104}$ Most recently in Post Danmark A/S v Konkurrenceraddet, the European Court of Justice upheld the standard from $A k z o$ and emphasized that where a firm sets price above AVC, but below ATC, a violation can be found if an intent to harm a competitor is found. ${ }^{105}$

Article 17 of China's Antimonopoly Law prohibiting the abuse of a dominant position provides an example of abuse as selling products at prices below cost without a legitimate reason. ${ }^{106}$ The Article, however, gives no indication of what cost will be used to measure "below cost."107 The National Development and Reform Commission drafted regulations to define below cost as charging a price that would cause the firm to incur a loss with the intent to exclude competitors. ${ }^{108}$ This regulation has not yet been adopted.

In order to prove a case, the plaintiff in a PRC predatory pricing case must show that the firm charging the low price has market power or is in a dominant position. ${ }^{109}$ Similar to EU predatory pricing law, recoupment does not need to be shown for a predatory pricing violation. ${ }^{110}$ The law also indicates that a defendant in a predatory pricing case will be able to present procompetitive justifications as a defense for their pricing policy. ${ }^{111}$

Section 8(c) of the South African Competition Act states that it is prohibited for a dominant firm to engage in an exclusionary act. ${ }^{112}$ Section 8(d)(iv) then states that such an exclusionary act includes selling goods

\footnotetext{
${ }^{101}$ Case C-62/86, Akzo Chemie BV v. Comm'n, 1991 E.C.R. I-3439, I-3455.

${ }^{102} \mathrm{Id}$. at I-3455.

${ }^{103} \mathrm{Id}$.

${ }^{104}$ Case T-340/03, France Télécom v. Comm’n, 2007 E.C.R. II-181; Case T-83/91, Tetra Pak Int'l v. Comm'n, 1994 E.C.R. II-827.

${ }^{105}$ Case C-209/10, Post Danmark A/S v. Konkurrencerådet, Judgment, 2012 E.C.R. 172, ๆ 27; Howard Rosenblatt et al., Post Danmark: Predatory Pricing in the European Union, EUR. ANTITRUST REV., 2013, at 21.

${ }^{106}$ Adrian Emch \& Gregory K. Leonard, Predatory Pricing in China: In Line with International Practice?, LEGAL ISSUES ECON. INTEGRATION 305, 306 (2010), https://papers.ssrn.com/sol3/papers.cfm?abstract_id=1713782

${ }^{107} \mathrm{Id}$.

${ }^{108} \mathrm{Id}$.

${ }^{109} \mathrm{Id}$. at 308

${ }^{110} \mathrm{Id}$. at 312

${ }^{111} \mathrm{Id}$. at 314

${ }^{112}$ Competition Act 89 of 1998 \& 8 (S. Afr.).
} 
below their "marginal or average variable cost." 113 There have been a small number of notable predatory pricing cases brought in South Africa, the first being the case brought by Nationwide Airlines against South African Airways. ${ }^{114}$ The Nationwide case established that pricing below average variable cost raises a presumption of anticompetitive effect. ${ }^{115}$ In a second airline case, this time brought by the South African Competition Commission, the tribunal held that the plaintiff bears the burden of proving anticompetitive effects of the pricing policy implemented by the defendant. $^{116}$

In the most recent case brought by the Commission against Media 24, the Competition Tribunal dismissed a predatory pricing case under 8(d)(iv) because the plaintiff did not establish that the price was set below average avoidable cost, the measure of the cost that the firm could have avoided by not engaging in predatory behavior. ${ }^{117}$ The tribunal however did find a violation under $8(\mathrm{c})$ because the plaintiff did show pricing below average total cost, predatory intent, and recoupment on behalf of the defendant. ${ }^{118}$

Predatory pricing claims outside the United States require a high burden of proof in most jurisdictions. ${ }^{119}$ However, in not requiring recoupment, they remain part of the canon of competition law in most jurisdictions outside the United States.

\section{F. Margin Squeezes}

Closely related is the international divergence on the question of price squeeze or margin squeeze claims. A price squeeze arises when a vertically integrated dominant firm also acts as a supplier to competitors in some upstream market. ${ }^{120}$ The notion of a price squeeze is that the dominant firm sets input prices so high that no competitor can then successfully enter or compete with the dominant firm in the downstream market.

In the past, the United States appeared to accept such claims in the aluminum industry. Alcoa, the monopoly supplier of virgin aluminum ingot,

${ }^{113} I d$

114 NeIl MaCkenzIE, Bell Dewar, ARE SOUth AFriCA's Predatory Pricing Rules SuITABLE? 11 (last visited Mar. 6, 2018); Nationwide Airlines v. S. African Airways 20011 (Tribunal) (S. Afr.).

${ }^{115}$ Nationwide Airlines v. S. African Airways 20011 at 10; MACKENZIE, supra note 114, at 11.

${ }^{116}$ MACKENZIE, supra note 114, at 11-12; see also Comm ' $n$ v. S. African Airways 20051 (Tribunal) at 35 para. 132-35 (S. Afr.) ("In terms of 8(c) we then consider whether the anti-competitive effect outweighs any efficiency justification for the conduct. If it does we can find that there has been an abuse of dominance. Here again the onus is on the complainant.").

117 Comm'n v. Media 24 Ltd. 20151 (Tribunal) at 53, para. 211-12 (S. Afr.).

${ }^{118} \mathrm{Id}$. at 150 para. 621 .

${ }^{119}$ See supra Part I.C (discussing what kinds of practices rise to the level of predatory pricing in various jurisdictions outside of the United States).

120 J. Gregory Sidak, Abolishing the Price Squeeze as a Theory of Antitrust Liability, $4 \mathrm{~J}$. COMPETITION L. \& ECON. 279, 279 (2008). 
set prices of outside fabricators of finished aluminum products, such as pots and pans, so high that such downstream competitors could not effectively compete with the finished products made by Alcoa itself. ${ }^{121}$

In 2008, the United States Supreme Court reached precisely the opposite conclusion in Linkline Communications. ${ }^{122}$ Linkline concerned allegations that an incumbent telephone company had overcharged competing internet access providers for access to its telephone lines. ${ }^{123}$ Relying on Trinko, the Court held that since the defendant had no antitrust duty to provide access, it could not incur liability for providing access at allegedly too high a price. ${ }^{124}$ The Court further held that the only potential cause of action for the plaintiff would be if the dominant firm engaged in predatory pricing of its broadband services in the downstream market, including both proof of price below some economically relevant measure of cost and the likelihood of recoupment as set forth in Brooke Group. ${ }^{125}$

Since the EU diverges significantly from the results of both Trinko and Brook Group, it is not surprising it also follows a different path as to price squeeze cases, which by their nature incorporate aspects of both access and pricing claims. For example, the European Court of Justice upheld liability in the 2010 Deutsche Telekom (DT) margin squeeze decision. ${ }^{126}$ The court affirmed liability where the dominant telephone firm charged excessive prices for access to telephone lines necessary to compete with DT for selling broadband service to consumers. ${ }^{127}$ The ECJ reached a similar result in the 2014 Telefonica decision involving the dominant Spanish telephone provider's pricing of phone lines to its broadband competitors. ${ }^{128}$

The UK has considered a number of margin squeeze cases and most prominently found liability in the Genzyme decision. ${ }^{129}$ Genzyme controlled a drug necessary for the care of a rare, but devastating, illness called Gaucher

\footnotetext{
${ }^{121}$ United States v. Alumininum Co. of Am., 148 F.2d 416, 436-38 (2d Cir. 1945). See generally SPENCER WeBer WALLER, THE StORY of AlCOA: THE ENDURING Questions of MARKET POWER, CONDUCT, AND REMEDY IN MONOPOLIZATION CASES, ANTITRUst STORIES 121-22 (Eleanor M. Fox \& Daniel A. Crane eds., 2007) (introducing United States v. Aluminum Co. of America and emphasizing its significance in American antitrust law).

${ }^{122}$ Pac. Bell Tel. Co. v. Linkline Commc'ns, Inc., 555 U.S. 438, 450-51 (2009).

${ }^{123} \mathrm{Id}$. at 438 .

${ }^{124} I d$. at $450-5 \mathrm{I} ; \mathrm{Id}$. at $439-40$.

${ }^{125} \mathrm{Id}$. at 451 .

${ }^{126}$ Case C-280/08 P, Deutsche Telekom AG v. Comm'n, 2010 E.C.R. I-9614-15, I-9717.

${ }^{127} \mathrm{Id}$ - 183 ; see also Case C-52/09, Konkurrensverket v. TeliaSonera Sveirge AB, 2011 E.C.R. I566 , I-575-76, I-599.

${ }^{128}$ Case C-295/12 P, Telefónica SA \& Telefónica de España v. Comm'n, 2014 E.C.R. 2062, ศๆ 9, 24, 237; Case T-851/14, Slovak Telekom v. Comm'n, 2018 ๆ 110-12, http $/ /$ curia.europa.eu/juris/document/document jsf?text $=\&$ docid $=209008 \&$ pageIndex $=0 \&$ doclang=en $\&$ mode $=1$ st\&dir $=\& o c c=$ first\&part $=1 \& c i d=10279707$; Case E-6/17, Fjarskipti hf. v. Siminn hf., 2018 ๆ 73, https://eftacourt.int/wp-content/uploads/2019/01/6_17_Judgment_EN.pdf.

129 Exclusionary Behaviour by Genzyme Ltd., [2003] No. CA98/3/03, ๆ 387 (UK), https://assets.publishing.service.gov.uk/media/555de4c440f0b666a200015c/genzyme.pdf.
} 
disease. ${ }^{130}$ The defendant provided both the drug and the care system for those taking the medication. ${ }^{131}$ It later began supplying the drug to an outside health provider, but at the same price it charged for the drug and the care system including nursing staff. ${ }^{132}$ The Office of Fair Trading, the former UK competition agency, found this behavior to be unlawful, stating:

A pricing policy operated by a vertically integrated dominant undertaking may infringe ... the Act. This might occur where a vertically integrated undertaking which is dominant in the upstream market operates a pricing policy which does not allow reasonably efficient competitors in the downstream market a margin sufficient to enable them to survive in the long term. ${ }^{133}$

A 2009 OECD roundtable on margin squeezes states:

Margin squeeze cases are relatively common. Many competition authorities have examined at least a few complaints involving a potentially illegal margin squeeze. Many of these cases arise in newly liberalised sectors particular [sic] telecommunications, but also in the water sector, railways, postal services, pharmaceuticals, pay television, gasoline, and funeral services (amongst others). ${ }^{134}$

The executive summary of the OECD roundtable also notes that almost all margin squeeze cases arise under the general prohibition of abuse of dominance provisions in national competition laws. ${ }^{135}$ It also specifically mentions a German statutory provision addressing margin squeeze cases in relation to small and medium-sized companies. ${ }^{136}$

There are a number of critiques of price squeeze claims on theoretical and empirical grounds ${ }^{137}$ It nonetheless remains the case that the position of

\footnotetext{
${ }^{130} \mathrm{Id} \cdot \boldsymbol{\top} 5$

${ }^{131} \mathrm{Id}$. ๆศ $5-8$.

${ }^{132} \mathrm{Id}$.

${ }^{133}$ Id. 9 364; see also Office of Gas \& Elec. Mkts. [OFGEM], Decision to Accept Binding Commitments from Elec. N. W. Ltd. Over Connection Charges, at 31, 35 (May 24, 2012), https:/www.ofgem.gov.uk/system/files/docs/2017/04/final-draft-17-may.pdf (accepting commitments from regulated electrical utility to cease margin squeeze allegation regarding access to its electrical grid).

134 See ORG. For ECON. Co-OPERATION \& DEv. [OECD], POliCy Roundtables: MARgin SQUEEZE 8 (2009), http://www.oecd.org/regreform/sectors/46048803.pdf (surveying practices in twentyfive jurisdictions).

${ }^{135} \mathrm{Id}$.

${ }^{136} \mathrm{Id}$.

${ }^{137}$ See, e.g., Erik Hovenkamp \& Herbert Hovenkamp, The Viability of Antitrust Price-Squeeze Claims, 51 ARIZ. L. REV. 273, 297 (2009) (criticizing price squeeze claims on the grounds that they could actually encourage price fixing and that allowing courts to predict the "correct price" in these situations places the court in a position of a public utility regulator, and finding few circumstances in which liability for price-squeezing is appropriate); Sidak, supra note 120, at 281 (questioning "whether price-squeeze
} 
the United States on such issues as excessive pricing, predatory pricing, and access to infrastructure have led it to abandon enforcement in price and margin squeeze cases. In contrast, much of the rest of the international competition community brings such claims when the facts so indicate.

\section{G. Tying and Bundling}

Tying is the practice where a seller uses its market power over one good or service to coerce a buyer into taking a second good or service it may not want or may wish to purchase from a different seller. ${ }^{138}$ Examples include requiring buyers to purchase machine tools and the ingredients for the products made with the machines; contracts requiring use of a designated anesthesia group in all hospital operating rooms; and forcing buyers to purchase both spare parts and service from the manufacturer of the copying equipment, rather than from an independent service provider.

In Jefferson Parish, the United States Supreme Court set forth a quasi per se rule for tying under the Sherman and Clayton acts. ${ }^{139}$ This per se standard for tying requires proof of four elements: (1) that the tying and tied items entail separate products or services in the sense that there is separate demand for each of them without the other; (2) that the availability of the tying item has been conditioned upon purchase, rental, or license of the tied item; (3) that the party imposing the tie has sufficient market power for the tying item to "appreciably restrain free competition" in the tied market; and (4) that a "not insubstantial amount of commerce" in the tied item is affected by the tying arrangement. ${ }^{140}$

Jefferson Parrish was unanimous in its result that the plaintiff failed to prove the third element of the per se standard for tying-showing the defendant had market power over the tying product. ${ }^{141}$ The decision also included a concurrence by Justice O'Connor, joined by two other Justices. The O'Connor concurrence argued for the adoption of the full rule of reason test for all tying claims and also argued that complementary products should

\footnotetext{
concept aids or hinders coherent analysis under section 2 of the Sherman Act"); see also Bradley Aburn, Margin Squeezing: The Superfluous "Fancy Phrase" of New Zealand Competition Law, 18 AUCKLAND U. L. REV. 216, 230 (2012) (noting that price squeezing could benefit consumers, as it "does not give a dominant firm more power than it already has"); Germain Gaudin \& Despoina Mantzari, Margin Squeeze: An Above-Cost Predatory Pricing Approach, 12 J. COMPETITION L. \& ECON. 151, 155 (2016) (criticizing the EU approach to price-squeeze liability as over-deterring, and finding that "because of the so-called 'umbrella effect,' a dominant firm would face a de facto price floor at the retail level once the wholesale price is set, if squeeze is too broadly defined and punished by law").

${ }^{138}$ Eastman Kodak Co. v. Image Tech. Servs., Inc., 504 U.S. 451, 451 (1992).

139 Jefferson Par. Hosp. Dist. No. 2 v. Hyde, 466 U.S. 2, 2-3 (1984).

${ }^{140} \mathrm{Id}$. at $2,3,15-18,34$.

${ }^{141} I d$. at $2,31-32$.
} 
not be viewed as a tie of separate products even if there was some demand for different sources of the complementary good or services. ${ }^{142}$

The United States Supreme Court reaffirmed this quasi per se test in its subsequent decision in Eastman Kodak. ${ }^{143}$ The Court also took no steps to abandon the quasi per se rule in the more recent Independent Ink decision dealing with the market power requirement of tying law. ${ }^{144}$

The D.C. Circuit, in its 2001 Microsoft decision, believed that a full rule of reason test should apply to claims of technological tying and sought to distinguish this result from the more general quasi per se rule set forth by the United States Supreme Court in Jefferson Parish ${ }^{145}$ Additional lower courts have from time to time applied a rule of reason analysis on alternative rationales, rather than applying the current prevailing quasi per se test from Jefferson Parish. ${ }^{146}$

The EU approaches these issues very differently. Article 101 of the Treaty on the Functioning of the European Union provides that all agreements that have as their object or effect the prevention, restriction, or distortion of competition are prohibited. ${ }^{147}$ Article 101(d) defines such an agreement as any agreement that: "make[s] the conclusion of contracts subject to acceptance by the parties of supplementary obligations which . . . have no connection with the subject of such contract[]."148

Article 102(d) also states that an unlawful abuse of dominance can include "making the conclusion of contracts subject to acceptance by the parties of supplementary obligations which . . have no connection with the subject of such contract."149 As a result, tying agreements can be both an abuse of dominance and an illegal agreement under EU law.

In Tetra Pak, the ECJ Court illustrated how tying can be regulated under Article 102 and that tying arrangements constitute an abuse of a dominant position if the abuse is not objectively justified. ${ }^{150}$ The ECJ affirmed liability for the tying of the sale of machinery for packaging of liquid and semi-liquid food products to the sale of the cartons themselves. The court noted that tying by a dominant firm would be unlawfully abusive without objective justification, even if in accordance with commercial usage or if there was a natural link between the two items. ${ }^{151}$

\footnotetext{
${ }^{142} I d$. at 33-34.

${ }^{143}$ Eastman Kodak Co., 504 U.S. at 451-53.

${ }^{144}$ IIl. Tool Works Inc. v. Indep. Ink, Inc., 547 U.S. 28, 42 (2006)

${ }^{145}$ United States v. Microsoft Corp., 253 F.3d 34, 89 (D.C. Cir. 2001).

${ }^{146}$ See In re Cox Enters., Inc., 871 F.3d 1093, 1104 (10th Cir. 2017) (applying a mixture of the per se test and Jefferson Parish factors)

${ }^{147}$ TFEU art. 101.

${ }^{148}$ Id. art. $101(\mathrm{~d})$

${ }^{149} I d$. art. $102(\mathrm{~d})$

${ }^{150}$ Case C-333/94P, Tetra Pak Int'1 SA v. Comm'n, 1996 E.C.R. I-5951

${ }^{151}$ Id. at I-6010-11.
} 
The EU Microsoft case also illustrates how the tying offense in the EU is broader than the U.S. approach. ${ }^{152}$ Microsoft states that in the EU, distinctness of products can be established by looking to consumer demand. ${ }^{153}$ Distinctness can be shown through direct consumer evidence or indirect evidence such as the presence of other firms in the market that sell the tied product without the tying product. ${ }^{154}$ But it is important to note that the EU Commission imposed liability, affirmed by the General Court, for the tying of the Windows Media Player to the operating system. ${ }^{155}$ This result is in marked distinction to the tying claims regarding internet browsers and operating systems reversed and remanded by the D.C. Circuit and ultimately abandoned by the Justice Department in the U.S. Microsoft litigation. ${ }^{156}$

Microsoft also was found liable for the tying of various software applications with its dominant network server operating system. While EU defendants can still prevail if they offer a sufficient objective justification including efficiencies, such justifications rarely prevail and were rejected in the EU Microsoft decision. ${ }^{157}$ This divergence with the evolving U.S. approach to tying is highlighted in the criticism by U.S. politicians, enforcement officials, and commentators. ${ }^{158}$

In the merger context, the European Commission has also expressed fear over future tying and bundling by dominant firms with a wide range of products to the detriment of competitors with less extensive products lines as one of the grounds for barring the General Electric/Honeywell merger in the aviation industry. ${ }^{159}$ The United States subsequently organized a roundtable at the OECD where it was highly critical of this and other aspects

${ }^{152}$ Case T-201/04, Microsoft Corp. v. Comm'n, 2007 E.C.R. II-3601, I-3613-14, 5 C.M.L.R. 11 (2007) [hereinafter Microsoft EU].

${ }^{153} \mathrm{Id}$. at II-3613, ๆ 16.

${ }^{154}$ Id. at I-3613.

${ }^{155} \mathrm{Id}$. at II-3601.

${ }^{156}$ United States v. Microsoft, 253 F.3d 34, 89 (2001)

${ }^{157}$ Microsoft EU, supra note 152, Фๆ 690, 707.

${ }^{158}$ GIFFORD \& KUdRLE, supra note 5, at 182-84; WILlIAM H. PAGE \& JOHN E. LOPATKA, THE Microsoft CASE: Antitrust, High TeChNology, and Consumer Welfare 81-83 (2007); James Kantor et al., EU Imposes Sanctions on Microsoft, WALL ST. J. (Mar. 25, 2004), https://www.wsj.com/articles/SB108012031906164011?ns=prod/accounts-wsj. Then Senate Majority Leader Bill Frist condemned the Commission's action, claiming that Europe's economies were stagnant because of huge debt, taxes, and crippling business regulation in Brussels. Mr. Frist expressed that the "European Commission has taken aim at Microsoft, a company whose products and technology have been engines of global economic growth." Id. R. Hewitt Pate, the Justice Department antitrust chief, said the Commission's demand that a Windows version be offered without the media player went too far. Id. He expressed concerns that "imposing "code removal' remedies" could potentially produce unintended consequences down the road, mentioning that "sound antitrust policy must avoid chilling innovation and competition even by "dominant' companies." Id.

${ }^{159}$ Commission Decision 2004/134/EC of 3 July 2001, declaring a concentration to be incompatible with the common market and the EEA Agreement Case COMP / M.2220 - General Electric/Honeywell, 2006 O.J. (L 48$) 1$ (EC); Case T-210/01, Gen. Elec. Co. v. Comm'n, 2005 E.C.R. II-5575. 
of the EU's approach in GE/Honeywell. ${ }^{160}$ Tying and bundling concerns remain a staple of EU conglomerate merger analysis and have led to the imposition of behavioral remedies in several recent transactions that were cleared unconditionally by the United States. ${ }^{161}$

A 2009 ICN survey on tying practices around the world indicates a high degree of diversity as to the requirements of tying offenses with many jurisdictions within the EU and elsewhere actively enforcing such provisions. ${ }^{162}$ For example, the German Bundeskartellampt indicated that it is not necessary for tying conduct to cause direct consumer harm. It is sufficient that "the conduct is detrimental to competition and to an effective market structure and thus harms consumers indirectly."163

Article 17 of the Chinese Anti-Monopoly Law states that an abuse of a dominant position can occur where a firm, without justifiable reasons, imposes tying. ${ }^{164}$ In the PRC Tetra Pak case, the defendant was accused of tying packing materials with its sale of paper packing equipment. ${ }^{165}$ The State Administration for Industry and Commerce (SAIC) found that Tetra Pak's practices were harmful as they limited customer choice, affected sales of competitors, and restricted competition. ${ }^{166}$

Tetra Pak offered justifications for its tying practice that were rejected by the SAIC. It claimed that tying was necessary to ensure performance and that tying also protected consumer health and safety. The SAIC found that there were other high-quality packing materials that sufficiently ensured performance of Tetra Pak's equipment, and that Tetra Pak failed to show that other packing materials inadequately protected consumer health and safety. ${ }^{167}$

In Qihoo v. Tencent, the first anti-monopoly case heard by the Chinese Supreme Court, the court laid out five criteria to be considered in a tying case. ${ }^{168}$ These include: (1) a tied product distinct from the tying product; (2)

${ }^{160}$ Org. FOR ECON. CO-OPERATION \& DEV., PORTFOlio EFFECTS IN CONGLOMERATE MERGERS 261-62 (2001), www.oecd.org/competition/mergers/1818237.pdf.

${ }^{161}$ Strati Sakellariou-Witt \& Jan Jeram, The EU Approach to Conglomerate Effects, WHITE \& CASE (May 18, 2018), https://www.whitecase.com/publications/insight/eu-approach-conglomerate-effects.

${ }^{162}$ INT'L COMPETITION NETWORK, REPORT ON TYING AND BUNDLED DisCOUNTING 7 (2009), https://www.internationalcompetitionnetwork.org/wpcontent/uploads/2018/07/UCWG_SR_TyingBund Disc.pdf.

${ }^{163} \mathrm{Id}$. at 14

${ }^{164}$ Anti-monopoly Law of the People's Republic of China (promulgated by the Standing Comm. Nat'l People's Cong., Aug. 30, 2007, effective Aug. 1, 2008), art. 17 (China), http://www.npc.gov.cn/englishnpc/Law/2009-02/20/content_1471587.htm.

${ }^{165}$ Herbert Smith Freehills LLP, China's SAIC Fines Tetra Pak RMB667.7m for Abuse of Dominance, LEXOLOGY (Dec. 1, 2016), https://www.lexology.com/library/detail.aspx?g=f136b8feaaf2-432e-b409-ec99dac0f990.

${ }^{166} I d$. (discussing SAIC Competition Enforcement Public Notice No. 10).

${ }^{167} \mathrm{Id}$.

${ }^{168}$ Beijing Qihoo Tech. Co. v. Tencent Tech. (Shenzhen) Co., 2013 CIV. JUDG. at 78-80 (Sup. People's Ct. Oct. 16, 2014) (China). 
a defendant with a dominant position in the tying market; (3) consumers required to accept the tied product along with the tying; (4) that there is no justifiable reason for the tie; and (5) a negative impact on competition. ${ }^{169}$ The court ultimately did not find illegal tying as there was a lack of restriction on consumers shown, and because there was no evidence of a dominant position in the tying market. ${ }^{170}$ Tying allegations involving essential and non-essential patents were also an important part of the Qualcomm and other intellectual property antitrust cases in the PRC. ${ }^{171}$

Chapter II, section 3(4) of the Indian Competition Act of 2002 provides that any tie-in arrangement shall be prohibited if the agreement has "an appreciable adverse effect on competition in India." 172 A rule of reason analysis applies to tying arrangements in India. This involves looking to the adverse effects on competition as well as any benefits shown from the tying arrangement. Chapter IV, section 19 of the Competition Act provides what should be looked at in a section 3 analysis when determining if there are appreciable adverse effects on competition: (1) creation of barriers to new entrants; (2) driving existing competitors out of the market; (3) foreclosure of competition by hindering entry; (4) accrual of benefits to consumers; (5) improvements in production or distribution of goods and services; and (6) promotion of technical, scientific, and economic development. ${ }^{173}$

Illegal tying also was found in Consumer Online Foundation v. Tata Sky Ltd. where television service was denied to customers unless customers also purchased hardware from the provider. ${ }^{174}$ The Commission found that this was an unlawful tying arrangement under Section 3(4) of the Competition Act, and that it was likely to have an adverse effect on the market given that the service providers controlled eighty percent of the service market. ${ }^{175}$

Tying and bundling claims illustrate the same dynamic as most types of abuse of a dominant position. The United States has been shrinking or eliminating the scope of such claims, which remain more available to public and private enforcers in other jurisdictions.

\section{H. Single Product Rebates}

Single product discounts or rebates refer to a situation where a firm grants substantial discounts (sometimes on an ever-increasing basis) where the buyer achieves certain targets based on either aggregate purchases or percentages of purchases of that category of products or services. Such arrangements raise competition concerns when the discount effectively

${ }^{169} \mathrm{Id}$. at $79-80$

${ }^{170} \mathrm{Id}$. at $25-26$

${ }^{171}$ See supra note 61 and accompanying text.

${ }^{172}$ Competition Act, No. 12 of 2003, INDIA CODE (2002), ch. II, § 3(4).

${ }^{173}$ Id. ch. IV $\$ 19$

${ }^{174}$ Consumer Online Found. v. Tata Sky Ltd. \& Ors., (2011) 2 CCI 1, 12.4 (2009) (India).

${ }^{175} \mathrm{Id} \cdot \boldsymbol{\top} 2.8 .1$ 
forecloses an equally efficient competitor from being able to compete in the market for the sales to customers receiving the rebates or survive on the remaining sales opportunities in the market.

One example would be a market when there are several substantial purchasers buying one million widgets each per year and a small number of fringe purchasers buying a few thousand widgets annually. The largest widget supplier — but not necessarily the more efficient—creates a rebate program that provides a small rebate for all sales up to 999,999 units, and a whopping twelve percent rebate for the millionth sale and all prior sales for the year.

Single product discounts or rebates are rarely unlawful under U.S. antitrust law. In fact, they are often praised as a form of price competition representing the essence of the type of competition on the merits to be encouraged through antitrust law. ${ }^{176}$ Such discounts normally will be analyzed under the exacting standards for predatory pricing discussed above, ${ }^{177}$ and only found illegal where price after rebate is below some economically relevant measure of the discounter's costs and there is a likelihood that the discounting firm eventually can recoup its losses. ${ }^{178}$ Other times, such discounts will be analyzed under a more complex version of the predatory pricing analysis that involves attributing the full discounts to the portion of sales where the competing firms must match the discounts and then determining whether price is below cost and whether recoupment is likely. ${ }^{179}$ Even if the single product rebates or discounts result in a de facto exclusive dealing arrangement, it will, at most, be subject to the general rule of reason analysis for such contracts. ${ }^{180}$ Regardless of the standard used, most claims have been singularly unsuccessful in recent years with courts reluctant to impose liability for conduct viewed as closely resembling healthy price competition. ${ }^{181}$

${ }^{176}$ GIFFORD \& KUDRLE, supra note 5, at 117-18; 3 A PHILLIP E. AREEDA \& HERBERT HOVENKAMP, Antitrust LaW 311-12 (4th ed. 2015); I ABA Section of Antitrust LaW, Antitrust LaW DEVELOPMENTS 252 (6th ed. 2007) (noting that "such conduct is more often than not beneficial to consumers").

177 See supra notes $97-119$ and accompanying text.

${ }^{178}$ Concord Boat Corp. v. Brunswick Corp., 207 F.3d 1039, 1061-62 (8th Cir. 2000).

${ }^{179}$ Allied Orthopedic Appliances Inc. v. Tyco Health Care Grp. LP, 592 F.3d 991, $997-98$ (9th Cir. 2010).

${ }^{180}$ Tampa Elec. Co. v. Nashville Coal Co., 365 U.S. 320, 327 (1961) (evaluating facts and circumstances surrounding exclusive dealing arrangement to determine if the contract would "foreclose competition in a substantial share of the line of commerce affected"); Eisai, Inc. v. Sanofi Aventis U.S., LLC, 821 F.3d 394, 402-03 (3d Cir. 2016); ZF Meritor, LLC v. Eaton Corp., 696 F.3d 254, 271 (3d Cir. 2012); Brunswick, 207 F.3d at 1058-59

${ }^{181}$ See, e.g., Eisai, $821 \mathrm{~F} .3 \mathrm{~d}$ at 408 (noting that lower prices due to a lower cost structure does not demonstrate predatory pricing); ABA SECTION OF ANTITRUST LAW, supra note 176, at 253-55 (collecting cases); GIFFORD \& KUDRLE, supra note 5, at 117-18. Cf. In re Intel Corp., Docket No. 9341, 2010 WL 3180281 , at *7-8, *20-23 (FTC Aug. 4, 2010) (outlining consent decree forbidding discounts or rebates conditioned on customers achieving a certain sales target). 
The EU courts have been significantly more concerned with fidelity rebates and found numerous examples to be abuses of a dominant position. Certain portions of the cases further discuss such rebates in terms of unlawful price discrimination which can also be a violation of Article $102 .{ }^{182}$ The ECJ also has used reasoning that analogizes such rebates to de facto tying and exclusive dealing. ${ }^{183}$ Professor Ariel Ezrachi summarizes the EU approach as follows:

Fidelity rebates are objectionable when they stimulate customers to tie themselves to the dominant undertaking and create de facto exclusivity. Such rebates weaken the structure of competition in the market, strengthen the market power of the already dominant undertaking and act as a barrier to entry. It is therefore irrelevant that the tied undertaking willingly entered into the agreement and is benefitting in the short term from the rebates. ${ }^{184}$

Michelin is the classic case in this regard. Michelin was the dominant firm for replacement tires for buses and trucks. ${ }^{185}$ The ECJ condemned Michelin's highly opaque and unwritten year-end rebate program where each customer was provided rebates once it achieved total year sales figures set in excess of the prior year. ${ }^{186}$ In a later case, the General Court similarly rejected a revised rebate plan based on Michelin's failure to demonstrate that the plan was objectively economically justified or that it was truly a quantity-based discount rather than a loyalty-inducing discount. ${ }^{187}$ In several cases, the ECJ also found that there was no need to show actual harmful effects on competition to invalidate such rebates, or at most that the rebates were capable of producing such effects. ${ }^{188}$

The European Commission subsequently published guidance on the application of Article 102 in a more economically oriented manner and focused on proof of actual effects for fidelity rebates. ${ }^{189}$ Despite this development, two commentators still note:

\footnotetext{
${ }^{182}$ See supra notes 69-78 and accompanying text.

${ }^{183}$ Case 85/76, Hoffman-LaRoche v. Comm'n, 1979 E.C.R. 464, 540-43.

184 ARIEL EZRACHI, EU COMPETITION LAW: AN ANALYTICAL GUIDE TO THE LEADING CASES 182 (2d ed. 2010).

${ }^{185}$ Case 322/81, NV Nederlandsche Banden-Industrie Michelin v. Comm'n, 1983 E.C.R. 03466, $3470-71$.

${ }^{186}$ Id. at 3474. See also Case T-228/97, Irish Sugar plc v. Comm'n, 1999 E.C.R. II-2969, II-3031, II-3081 (discussing how the company's practices could not be justified and the company must refrain from these types of rebates).

${ }^{187}$ Case T-203/01, Manufacture Française des Pneumatiques Michelin v. Comm'n, 2003 E.C.R. II4071, II-4075, II-4078. See also Case C-95/04 P, British Airways v. Comm'n, 2007 E.C.R. I-2331, I2373, I-2397, I-2400 (rejecting loyalty inducing rebate scheme as not economically justified).

${ }^{188}$ Case C-549/10 P, Tomra Sys. ASA v. Comm'n, 2012 ECLI:EU:C:2012:221, ๆף 75, 81; Case T66/01, Imperial Chem. Indus. Ltd. v. Comm'n, 2010 E.C.R. II-2631, II-2642.

${ }^{189}$ Guidance on the Commission's Enforcement Priorities in Applying Article 82 of the EC Treaty to Abusive Exclusionary Conduct by Dominant Undertakings, 2009 O.J. (C 45) 7-8.
} 
Although both jurisdictions now employ some version of predatory pricing analysis in their consideration of singleproduct discounts, this superficial similarity rests on a structure of considerable difference. US courts have generally found loyalty discounts to be procompetitive .... In contrast, EU courts appear willing to ignore the complex models of the Commission and declare such discounting by dominant firms as abusive without considering competitive effects. In addition, the Commission's approach accepts a more inclusive cost standard for computing predatory pricing and gives less attention to recoupment or lasting market impact than would be expected in the United States. Some observers have seen the FTC Intel case as an innovation because it appeared . . . to move the United States in the direction the Commission favors, but the pricing conduct agreed in the settlement is difficult to interpret, and no adjudication was involved. ${ }^{190}$

The Commission Guidance and the more recent ECJ decision in Intel ${ }^{191}$ may have nudged the EU slightly back in the direction of the United States on this issue. However, that decision is equally opaque and final resolution is years in the future, ${ }^{192}$ leaving a persistent and substantial divergence in both substance and outcome on the treatment of single product rebates.

Outside the United States and the EU, single product rebates tend not to be analyzed through a predatory pricing lens. A 2016 OECD Roundtable on fidelity rebates concluded:

Tests for below-cost pricing, including the 'discount attribution test', are not a reliable way to identify the anticompetitive effects of a fidelity rebate scheme. A predatory pricing framework can identify cases in which firms use a fidelity rebate scheme to put in place a strategy of predatory foreclosure against an as-efficient competitor. However, it fails to identify cases in which consumers are harmed as a result of a firm excluding rivals without pricing below cost. While a price-cost test might be a useful analytical tool in some cases, it would be ineffective as a screening

\footnotetext{
${ }^{190}$ GIFFORD \& KUDRLE, supra note 5, at 138.

${ }^{191}$ Case C-413/14 P, Intel Corp. Inc. v. Comm'n, 2017 ECLI:EU:C:2017:632, q甲 1, 150.

${ }^{192}$ See Kevin Coates, The Court of Justice and Intel: An Overdue Ruling that was Still Over-Hasty?, 32 Antitrust 57, 57 (2018) ("But the Court of Justice's September 2017 ruling did not reach a final conclusion on the Commission's analysis of Intel's rebate system. . . As a result, it now looks possible that the case will celebrate its $20^{\text {th }}$ anniversary in 2020 without a final resolution.").
} 
device or safe-harbour in an assessment or prioritisation guide. ${ }^{193}$

Reasonable people may differ on the best approach to single product rebates. But few would contest the global divide in this area of dominant firm conduct.

\section{Bundled Discounts}

Bundled discounts involve situations where sellers offer substantial discounts based on the buyers achieving a certain purchase target across a spectrum of products or categories. A simple example cited in a leading U.S. case involves a seller of both shampoo and conditioner providing substantial discounts or rebates for a buyer purchasing a set quantity or percentage of their needs for both products and the competitive effect this could have on an equally efficient manufacturer of only one of these items. ${ }^{194}$

Unlike single product discounts, there are a number of U.S. antitrust cases dealing with this phenomenon and relatively few decisions in the EU. While the U.S. case law has yet to settle on a single consistent approach, the courts (with one prominent exception) have been equally as suspicious of such claims as in the single product rebate context. While there have been fewer cases outside the United States, the EU and other jurisdictions have addressed such claims more favorably both in abuse of dominance cases and merger investigations.

There has not yet been a U.S. Supreme Court ruling on the standards of legality for bundled discounts. The courts of appeals have utilized diverse approaches proceeding by analogy to theories of tying, exclusive dealing, and predatory pricing.

The principal appellate case imposing liability for bundled discounts across product lines is LePage's Inc. v. $3 M^{195}$ In LePage 's, the Third Circuit affirmed liability for monopolization of the market for transparent tape. ${ }^{196}$ The plaintiff was a successful manufacturer of private label tape sold in large office supply stores and other retailers. ${ }^{197} 3 \mathrm{M}$ responded to this threat by offering cash payments, signing bonuses, and other types of discounts if

193 Directorate for Fin. \& ENTER. AFFAIrS, COMPETITION COMM., ORG. FOr ECON. CO-

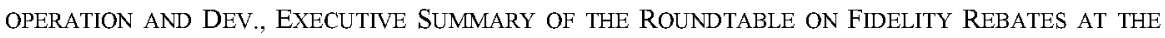
125TH MEETING OF THE COMPETITION COMMITTEE OF THE OECD 3 (2016), https:/one.oecd.org/document/DAF/COMP/M(2016)1/ANN4/FINAL/en/pdf.

${ }^{194}$ Ortho Diagnostic Sys., Inc. v. Abbott Labs., Inc., 920 F. Supp. 455, 467 (S.D.N.Y. 1996).

${ }^{195}$ LePage's Inc. v. 3M, 324 F.3d 141, 144 (3d Cir. 2003); see also Multistate Legal Studies, Inc. v. Harcourt Brace Jovanovich Legal \& Prof'1 Publ'ns, Inc., 63 F.3d 1540, 1543 (10th Cir. 1995) (stating bundled discounts of different types of Bar Exam preparation courses and materials could be unlawful even where the bundled price exceeded the combined cost of production).

${ }^{196}$ LePage's Inc., 324 F.3d at 144.

${ }^{197} \mathrm{Id}$. 
customers achieved certain sales targets across multiple 3M products lines for tape, office supplies, health care, and other products. ${ }^{198}$ LePage's, as a manufacturer of tape only, could not match these bundled discounts regardless of whether or not the discounts fell below some relevant measurement of 3M's costs. ${ }^{199}$

Most of the rest of the case law on bundled prices have used different versions of predatory pricing analyses. One federal appellate court applying the state antitrust laws of Colorado stated, "when sales of more than one item are bundled, whether in a single transaction or in the form of coupons or other concessions, compliance with the statute is determined by comparing the selling price to the cost of all items "included in such transaction[]." 200

A leading Ninth Circuit case took a different approach also based on viewing the bundled discounts as a form of predatory pricing. In Cascade Health, the court explicitly rejected the LePage's approach in connection with allegations that a dominant hospital bundled acute care services with other more specialized forms of care if insurance companies selected Cascade Health as their exclusive provider for their insurance networks. ${ }^{201}$ In so doing, the Ninth Circuit overturned a jury verdict in favor of a smaller hospital that only provided acute care services.

The court held:

To prove that a bundled discount was exclusionary or predatory for the purposes of a monopolization or attempted monopolization claim under $\S 2$ of the Sherman Act, the plaintiff must establish that, after allocating the discount given by the defendant on the entire bundle of products to the competitive product or products, the defendant sold the competitive product or products below its average variable cost of producing them. ${ }^{202}$

The 2000 report of the Antitrust Modernization Commission was even more negative about prospects for bundled discount claims that did not meet the full requirements of predatory pricing claims under Brooke Group. That report noted:

\footnotetext{
${ }^{198} I d$. at 145

${ }^{199}$ See also SmithKLINE Corp. v. Eli Lilly \& Co., 575 F.2d 1056, 1065 (3d Cir. 1978) (concluding proof of bundled prices being below cost is not required). But cf. ZF Meritor, LLC v. Eaton Corp., 696 F.3d 254, $274 \mathrm{n} .11$ (3d Cir. 2012) (limiting the approach in LePage's to multi-product rebates and affirming use of predatory pricing methodology for single product discount and rebate cases); FTC $v$. Church \& Dwight Co., 665 F.3d 1312, 1316-18 (D.C. Cir. 2011) (enforcing FTC subpoena in bundled discount case but noting that LePage's has been "roundly criticized" and that "this court might someday reach a different resolution").

${ }^{200}$ Parish Oil Co. v. Dillon Cos., 523 F.3d 1244, 1249 (10th Cir. 2008) (alteration in original).

${ }^{201}$ Cascade Health Sols. v. PeaceHealth, 515 F.3d 883, 891, 893, 898, 903 (9th Cir. 2008).

${ }^{202} I d$. at 910
} 
Courts should adopt a three-part test to determine whether bundled discounts or rebates violate Section 2 of the Sherman Act. To prove a violation of Section 2, a plaintiff should be required to show each one of the following elements (as well as other elements of a Section 2 claim): (1) after allocating all discounts and rebates attributable to the entire bundle of products to the competitive product, the defendant sold the competitive product below its incremental cost for the competitive product; (2) the defendant is likely to recoup these short-term losses and (3) the bundled discount or rebate program has had or is likely to have an adverse effect on competition. ${ }^{203}$

In contrast, there is very little EU case law on bundled discounts. The European Commission has weighed in on the issue in its Guidance on the Application of Article 82 (now Article 102). Here, the Commission took a relatively conservative position partially in line with the non-LePage's line of cases in the United States. ${ }^{204}$

In the absence of significant case law, it is difficult to say whether the European Court of Justice will follow this approach or revert to its more expansive treatment in line with its jurisprudence on single product discounts. Many of these cases involve multiple types of the same product, such as rebate schemes involving different types of tires which disadvantage producers of more limited product types. ${ }^{205}$ There are hints of this in the most recent ECJ Intel decision, but that case, as previously noted, was remanded for further proceedings and is years from final resolution. ${ }^{206}$ In addition, the European Commission and the ECJ has expressed concerns over range effects and bundled discounts across different product lines as part of its reasoning in prohibiting the GE-Honeywell conglomerate merger, ${ }^{207}$ a decision which produced fierce criticism in the United States. ${ }^{208}$

203 AnTitrust MODERnization COMM'N, REport AND RECOMMENDATIONS 12 (2007), https://govinfo.library.unt.edu/amc/report_recommendation/amc_final_report.pdf.

${ }^{204}$ Communication from the Commission - Guidance on the Commission's Enforcement Priorities in Applying Article 82 of the EC Treaty to Abusive Exclusionary Conduct by Dominant Undertakings, 2009 O.J. (C 45) ब 60, https://eur-lex.europa.eu/legalcontent/EN/TXT/PDF/?uri=CELEX:52009XC0224(01)\&from=EN

${ }^{205}$ See supra notes 191-94 and accompanying text.

${ }^{206}$ Case C-413/14, Intel Corp. Inc. v. Comm'n, 2017 ECLI:EU:C:2017:632, $\uparrow 150$.

207 Commission Decision 2004/134/EC of July 3, 2001, Declaring a Concentration to Be Incompatible with the Common Market and the EEA Agreement Case COMP / M.2220 - General Electric/Honeywell, 2006 O.J. (L 48) 1 (EC).

${ }^{208}$ See Press Release, Dep't of Justice, Statement by Assistant Attorney General Charles A. James on the EU's Decision Regarding the GE/Honeywell Acquisition (July 3, 2001) (on file with author) (noting that "[c]lear and longstanding U.S. antitrust policy holds that the antitrust laws protect competition, not competitors" and that this EU decision represented a significant point of divergence between EU and U.S. competition law); see also Charles A. James, International Antitrust in the Bush 
A 2009 survey of the ICN shows a strong diversity of practice of jurisdictions with respect to bundled discounts. ${ }^{209}$ The goals for enforcement in this area typically include but go beyond the promotion of consumer welfare cited by the United States. A number of jurisdictions do not require price-cost comparisons, do not require recoupment, and/or do not require proof of intent. ${ }^{210}$ France has been particularly active in this area with eight challenges to bundled discounts in the ten years preceding the report. ${ }^{211}$

\section{J. Essential Facilities Doctrine and Refusals to Deal}

One of the most striking illustrations of the retreat of the United States from a traditional theory of monopolization comes in the area of the essential facilities doctrine and other forms of unilateral refusals to deal. From the earliest days of U.S. antitrust law, the courts have imposed liability under both section 1 and section 2 of the Sherman Act on a firm or firms controlling an essential facility, often in the form of infrastructure such as bridges, electrical networks, joint newsgathering operations, and occasionally intellectual property, where the owner/operator refused access to a competitor and the other elements of an antitrust violation were present. $^{212}$

Although the United States Supreme Court has never specifically endorsed liability under this rubric, the lower courts have often used the "essential facilities doctrine" to impose liability for monopolization upon proof of:

1) Control by a monopolist of an essential facility or resource serving the monopolist's market;

\footnotetext{
Administration, DEP'T JUST. (Sept. 21, 2001), https://www justice.gov/atr/speech/international-antitrustbush-administration (criticizing the so-called "portfolio effects" analysis employed by the EU as "antithetical to the goals of antitrust law enforcement"); William J. Kolasky, Conglomerate Mergers and Range Effects: It's a Long Way from Chicago to Brussels, DEP'T Just. (Nov. 9, 2001), https://www justice.gov/att/speech/conglomerate-mergers-and-range-effects-its-long-way-chicagobrussels (stating the GE/Honeywell merger "triggered a firestorm of criticism, not just from the U.S. antitrust agencies and senior administration officials, but also from the business community").

${ }^{209}$ INT'L COMPETITION NETWORK, REPORT ON TYING AND BUNDLED DisCOUNTING 3-4 (2009), https://www.internationalcompetitionnetwork.org/wp-content/uploads/2018/07/UCWG_SR_Tying BundDisc.pdf (providing an analysis of thirty-five jurisdictions with "respect to tying and bundled discounts").

${ }^{210} \mathrm{Id}$. at $15-17,19$

${ }^{211} \mathrm{Id}$. at 7 .

${ }^{212}$ Otter Tail Power Co. v. United States, 410 U.S. 366, 379-80 (1973); Associated Press v. United States, 326 U.S. 1, 4 (1945); United States v. Terminal R.R. Ass'n of Saint Louis, 224 U.S. 383, 39091, 411-12 (1912); Aspen Highlands Skiing Corp. v. Aspen Skiing Co., 738 F.2d 1509, 1513, 1522, 1525 (10th Cir. 1984), aff'd on other grounds, 472 U.S. 585, 611 (1985). In addition, the government's landmark monopolization case resulting in the breakup of the monopoly Bell System telephone network was based in part on the essential facilities doctrine. See Brett Frischmann \& Spencer Weber Waller, Revitalizing Essential Facilities, 75 ANTITRUsT L.J. 1, 5-7 (2008) (explaining the history of Supreme Court cases in the essential facilities area).
} 
2) A competitor's inability practically or reasonably to duplicate the essential facility;

3) The unjustified denial of the use of the facility to a competitor; and

4) The feasibility of providing access to the facility. ${ }^{213}$

Liability on this theory was always difficult to establish factually, and numerous cases failed because either the defendant lacked market power, the facility controlled by the monopolist was not "essential" in any normal sense of the term, or the excluded competitor could reasonably create or duplicate the facility in question. ${ }^{214}$ In addition, liability was sometimes imposed on a general refusal to deal or general monopolization theory, blurring the lines of the acceptability of the essential facilities doctrine as a separate theory of liability. ${ }^{215}$

The Supreme Court in the Trinko decision limited the essential facilities doctrine in the context of regulated industries and provided dicta questioning its overall viability. ${ }^{216}$ As commentators described the decision: "The case primarily concerned the issue of whether it was an act of monopolization for a regulated telephone company to fail to comply with special network sharing obligations imposed on it by the Federal Telecommunications Act." 217

The Court held that the alleged violations of regulatory duties by themselves did not further provide a cause of action under section 2 of the Sherman Act. ${ }^{218}$ The Court found no additional support for the complaint in the plaintiff's alternative theory based on the essential facilities theory.

The Court first stated that it had never recognized such a doctrine and found no need in Trinko itself to either recognize or repudiate it. ${ }^{219}$ But assuming the doctrine applied, the Court stated in dicta that the claim would fail on the question of denied access. The Court stated:

It suffices for present purposes to note that the indispensable requirement for invoking the doctrine is the unavailability of access to the "essential facilities"; where access exists, the doctrine serves no purpose. Thus, it is said that "essential facility claims should ... be denied where a state or federal

\footnotetext{
${ }^{213}$ MCI Commc'ns Corp. v. Am. Tel. \& Tel. Co., 708 F.2d 1081, 1132-33 (7th Cir. 1983).

${ }^{214}$ William C. Holmes \& Melissa H. Mangiaracina, ANTITrust Law HandBook $§ 3.12$ (2017-18 ed.) (collecting cases)

${ }^{215}$ Aspen Highlands Skiing Corp., 738 F.2d 1509 (10th Cir. 1984), aff'd on other grounds, 472 U.S. 585 (1985).

${ }^{216}$ Verizon Commc'ns, Inc. v. Law Offices of Curtis V. Trinko, LLP, 540 U.S. 398 (2004).

${ }^{217}$ HOLMES \& MANGIARACINA, supra note 214, at 575.

${ }^{218}$ Trinko, 540 U.S. at $407-10$

${ }^{219} \mathrm{Id}$. at 411.
} 
agency has effective power to compel sharing and to regulate its scope and terms." 220

The continued vitality and desirability of the essential facilities doctrine and related unilateral refusal to deal claims remain hotly debated in the United States both before and after Trinko ${ }^{221}$ Whatever the answer to those questions, most courts and commentators believe that the application of such claims to the refusal to license intellectual property rather than physical infrastructure type facilities is either barred or limited to the most extraordinary circumstances. ${ }^{222}$

Current U.S. policy makes the pursuit of cases based on the refusal to license intellectual property rights highly unlikely. While one prominent case has imposed liability for refusal to license certain IP rights, even that court held that a monopolist's "desire to exclude others from its [protected]

\footnotetext{
${ }^{220} \mathrm{Id}$. (alteration in original) (citations omitted).

221 Compare RICHARD N. LANGLOIS, Technological Standards, Innovation, and Essential Facilities: Toward a Schumpeterian Post-Chicago Approach, in DYNAMIC COMPETITION AND PUBLIC POLICY: TECHNOLOGY, INNOVATION, AND ANTITRUST ISSUES 1993 (Jerry Ellig ed., 2001), Brett M. Frischmann, An Economic Theory of Infrastructure and Commons Management, 89 MINN. L. REV. 917 (2005), Brett Frischmann \& Spencer Weber Waller, Revitalizing Essential Facilities, 75 ANTITRUST L.J. 1 (2008), Brett M. Frischmann \& Mark Lemley, Spillovers, 107 COLUM. L. REV. 257 (2007), Marina Lao, Networks, Access, and "Essential Facilities": From Terminal Railroad to Microsoft, 62 SMU L. REV. 557 (2009), Ali A. Massadeh, The Essential Facilities Doctrine Under Scrutiny: EU and US Perspective (UEA Law, Working Paper No. 2011-AM-1, 2011), https://papers.ssrn.com/sol3/papers.cfm?abstract_id=1738326, Robert Pitofsky et al., The Essential Facilities Doctrine under U.S. Antitrust Law, 70 ANTITRUST L.J. 443 (2002), and Spencer Weber Waller, Areeda, Epithets, and Essential Facilities, 2008 WIS. L. REV. 359 (2008), with Philip Areeda, Essential Facilities: An Epithet in Need of Limiting Principles, 58 ANTITRUST L.J. 841 (1990), Michael Boudin, Antitrust Doctrine and the Sway of Metaphor, 75 GEO. L.J. 395, 397-403 (1986), and Richard J. Gilbert \& Carl Shapiro, An Economic Analysis of Unilateral Refusals to License Intellectual Property, 93 Proc. NAT'L ACAD. SCI. USA 12,749 (1996); Keith N. Hylton, Economic Rents and Essential Facilities, 1991 BYU L. REV. 1243 (1991); Allen Kezsbom \& Alan V. Goldman, No Shortcut to Antitrust Analysis: The Twisted Journey of the "Essential Facilities" Doctrine, 1996 COLUM. Bus. L. REV. 1187 (1999); Abbot B. Lipsky \& Gregory Sidak, Essential Facilities, 51 STAN. L. REV. 1187 (1999); Paul D. Marquandt \& Mark J. Leddy, The Essential Facilities and Intellectual Property Rights: A Response to Pitofsky, Patterson \& Hooks, 70 AnTITRUST L.J. 847 (2003); David McGowan, Regulating Competition in the Information Age: Computer Software as an Essential Facility Under the Sherman Act, 18 HASTINGS COMM. \& ENT. L.J. 771 (1996); Gregory J. Werden, The Law and Economics of the Essential Facilities Doctrine, 32 ST. LouIS U. L.J. 433 (1987).

${ }^{222}$ See Marquandt \& Leddy, supra note 221, at 848 (concluding that, under U.S. law, the essential facilities doctrine cannot "properly be applied to require licensing of an intellectual property right merely because in the absence of such a license rival firms will be unable to compete with the product incorporating the intellectual property"); Gilbert \& Shapiro, supra note 221, at 12,750-51 (discussing the refusal to deal and essential facilities doctrine).
} 
work is a presumptively valid business justification."223 Other decisions have come closer to a rule of per se legality. ${ }^{224}$

Change is not likely to come from the current U.S. enforcement regime. Makan Delrahim is the first head of the Antitrust Division who is also a member of the patent bar. ${ }^{225} \mathrm{He}$ is strongly protective of intellectual property rights and has been on record against the use of antitrust law to weaken IP protection for over twenty years.

As a member of the 2000 Antitrust Modernization Commission, he issued a dissenting opinion from the final $\mathrm{AMC}$ report stating:

In my view, antitrust law and policy must be careful not to constrain the legitimate exercise of intellectual property rights. The application of antitrust laws must not illegitimately stifle creators or innovation by condemning pro-competitive activities that would maximize incentives for investments or efficiency-maximizing business arrangements.

Antitrust enforcers should also strive to eliminate as much as possible the unnecessary uncertainties for innovators and creators in their ability to exploit their intellectual property rights, as those uncertainties can also reduce the incentives for innovation. Only when the holders of intellectual property rights go beyond the legitimate exercise of these rights should antitrust law be used to constrain their activities, and only then in a manner that is based on sound economic policies. ${ }^{226}$

As deputy head of the Antitrust Division in the Bush Administration, Delrahim consistently spoke out against forced licensing requirements and the dilution of intellectual property. ${ }^{227}$ As the current head of the Division,

${ }^{223}$ Image Tech. Servs., Ltd. v. Eastern Kodak Co., 125 F. 3d 1195, 1218 (9th Cir. 1997) (quotations omitted) (alteration in original); see also Data Gen. Corp. v. Grumman Sys. Support, 36 F.3d 1147, 1187 (1st Cir.1994) (noting that the "Copyright Act does not explicitly purport to limit the Sherman Act" and that "silence is particularly acute in cases where a monopolist harms consumers in the monopolized market by refusing to license a copyrighted work to competitors").

${ }^{224}$ See In re Indep. Serv. Org. Antitrust Litig., 203 F.3d 1322, 1327-28 (Fed. Cir. 2000) (asserting "in the absence of ... proof, we will not inquire into the patentee's motivations for asserting his statutory right to exclude").

${ }^{225}$ Makan Delrahim, Assistant Attorney Gen., Antitrust Div., Remarks at the USC Gould School of Law's Center for Transnational Law and Business Conference (Nov. 10, 2017), https://www.justice.gov/opa/speech/assistant-attorney-general-makan-delrahim-delivers-remarks-uscgould-school-laws-center; see also James Edwards, Order of the New Day: IP Rights in Dynamic Competition, IP WATCHDOG (June 10, 2018), https:/www.ipwatchdog.com/2018/06/10/order-newday-ip-rights-dynamic-competition/id=98212/.

226 DEBORAH A. GaRZa ET AL, ANTITRUST MODERNIZATION COMM'N, REPORT AND RECOMMENDATIONS 403, 404-05 (2007) (separate statement of Commissioner Delrahim).

${ }^{227}$ Makan Delrahim, Deputy Assistant Attorney Gen., Antitrust Div., International Antitrust and Intellectual Property: Challenges on the Road to Convergence, Remarks at the American Bar Association Section of Antitrust Law Conference on Antitrust \& Intellectual Property (May 21, 2004), 
he has given both speeches and testimony arguing for the increased protection of intellectual property rights and the need to protect IP creators over the competing needs of IP implementors. ${ }^{228}$ Most recently, over seventy-five law professors signed a letter to AAG Delrahim contending that his views were not even an accurate statement of U.S. policy on the complicated question of the intersection of antitust and intellectual property. $^{229}$

The treatment of refusals to deal for both physical assets and intellectual property is very different in the European Union, its member states, and other jurisdictions which have considered similar situations of a dominant firm controlling a resource necessary for competition in its own market or an adjacent one. Early in the jurisprudence of the ECJ, the court held that the refusal by a dominant firm to supply raw ingredients to a competitor that prevented competition in the downstream market for the finished compound was an abuse of dominance. ${ }^{230}$ Failures to grant access to infrastructure such as ports, rail lines, and electrical grids were condemned in terms strikingly

https://www.justice.gov/atr/speech/international-antitrust-and-intellectrual-property-challenges-roadconvergence (stressing the need for protection of intellectual property rights in the face of increasing globalization); Makan Delrahim, Deputy Assistant Attorney Gen., Antitrust Div., Contemporary Issues At The Intersection Of Intellectual Property and Antitrust, Remarks at The Fair Competition \& Market Economy 2004 Shanghai International Forum (Nov. 10, 2004), https://www.justice.gov/atr/speech/contemporary-issues-intersection-intellectual-property-and-antitrust (noting that "the antitrust laws do not serve their proper function if they are used to constrain the legitimate exercise of intellectual property rights or to stifle the innovation that is encouraged by a strong intellectual property regime"); Makan Delrahim, Deputy Assistant Attorney Gen., Antitrust Div., The Long And Winding Road: Convergence In The Application of Antitrust to Intellectual Property, Remarks at The George Mason Law Review Symposium (Oct. 6, 2004), https://www justice.gov/atr/speech/longand-winding-road-convergence-application-antitust-intellectual-property (urging that "antitrust enforcement policies must be carefully designed so they do not interfere with or discourage the legitimate exploitation of intellectual property rights through technology licensing").

${ }^{228}$ See, e.g., Makan Delrahim, Assistant Attorney Gen., Antitrust Div., Remarks at the USC Gould School of Law's Center for Transnational Law and Business Conference (Nov. 10, 2017), supra note 225; Makan Delrahim, Assistant Attorney Gen., Antitrust Div., Remarks at the U.S. Embassy in Beijing: Competition, Intellectual Property, and Economic Prosperity (Feb. 1, 2018), https://www.justice.gov/opa/speech/assistant-attorney-general-makan-delrahim-delivers-remarks-usembassy-beijing; Makan Delrahim, Assistant Attorney Gen., Antitrust Div., Keynote Address at University of Pennsylvania Law School, The "New Madison" Approach to Antitrust and Intellectual Property Law (Mar. 16, 2018), https://www.justice.gov/opa/speech/assistant-attorney-general-makandelrahim-delivers-keynote-address-university; Makan Delrahim, Assistant Attorney Gen., Antitrust Div., Remarks at the National Music Publishers Association Annual Meeting (June 13, 2018), https://www.justice.gov/opa/speech/assistant-attorney-general-makan-delrahim-delivers-remarksnational-music-publishers.

${ }^{229}$ Michael A. Carrier et al,, 7 Former Government Officials and Professors Remind Assistant AG Delrahim of Long-Standing U.S. Policy on Standard-Essential Patents, Foss PATs. (May 18, 2018), www.fosspatents.com/2018/05/77-former-government-officials-and.html.

${ }^{230}$ Case 6/73, Commercial Solvents Corp. v. Comm'n, 1974 E.C.R. 223, 1 C.M.L.R. 309. See also Case IV/32.279, BBI v. Boosey \& Hawkes plc, 1987 O.J. (L 286/36) 42, [1988] 4 C.M.L.R. 67. 
similar to the U.S. essential facilities doctrine. ${ }^{231}$ As in the United States, liability was rejected where the facility or resource controlled by the dominant firm was not truly essential or where the resource practically could be duplicated by the competitor. ${ }^{232}$ Many of the national competition authorities of the EU member states have applied these principles to require access by competitors or new entrants to more local essential infrastructure such as transportation and burial grounds. ${ }^{233}$

The EU has extended this doctrine to require access to intellectual property as well as physical resources. In Magill, the ECJ required Irish television stations to license their copyrighted program schedules to a new competitor seeking to aggregate the listings to create a multichannel viewer's guide. ${ }^{234}$ In $I M S$, this right of access was extended to require licensing of a copyrighted data structure to a competitor in order to directly compete with the dominant firm in the sale of health care information to pharmaceutical companies. ${ }^{235}$ In Microsoft, the General Court applied perhaps the most expansive version of the EU essential facilities doctrine to require the respondent to license interoperability information for its server operating system to competitors. ${ }^{236}$ A similarly expansive view was shown in an English Court of Appeals decision that the failure to license certain patents could constitute an unlawful abuse of dominance under Article $102 .^{237}$

Other jurisdictions have adopted some version of the essential facilities doctrine for both physical resources as well as intellectual property rights. Within the EU, the UK, Germany, the Czech Republic, Austria, Cyrus, Estonia, Greece, Italy, Luxembourg, and Lithuania have all applied versions of the doctrine to impose liability and/or require access or interconnection. ${ }^{238}$ Elsewhere countries as diverse as Argentina, Australia, Brazil, Canada, Chile, Israel, Japan, Guatemala, Mexico, New Zealand, the People's Republic of China, Peru, Turkey, Russia, and South Africa have used

${ }^{231}$ Case AT.39813, Baltic Rail, [2018] 4 C.M.L.R. 16; Case IV/34.689, Sea Containers Ltd./Stena Sealink, 1994 O.J. (L 15) 8.

${ }^{232}$ Case C-7/97, Oscar Bronner GmbH \& Co. KG v. Mediaprint Zeitungs, 1998 E.C.R. I-7791, [1999] 4 C.M.L.R. 112; Case T-504/93, Tiercé Ladbroke SA v. Comm'n, 1995 E.C.R. II-923, [1997] 5 C.M.L.R. 309.

${ }^{233}$ See Spencer Weber Waller \& William Tasch, Harmonizing Essential Facilities, 76 ANTITRUST L.J. 741, 745 (2010) (describing this phenomenon).

${ }^{234}$ Joined Cases C-241/91P \& 242/91P, RTE \& ITP v. Comm'n, 1995 E.C.J. I-743, [1997] 4 C.M.L.R. 718 .

${ }^{235}$ Case C-418/01, IMS Health GmbH \& Co. OHG v. NDC Health GmbH \& Co. KG, 2000 E.C.R. I-5039, [2004] 4 C.M.L.R. 28.

${ }^{236}$ Case T-201/04, Microsoft Corp. v. Comm'n, 2007 E.C.R. II-3601, [2007] 5 C.M.L.R. 11.

${ }^{237}$ Cases A3/2002/1380 \& A3/2002/1381, Intel Corp. v. Via Techs. Inc., [2002] EWCA Civ. 1905.

${ }^{238}$ Amadeo Arena, The Italian Council of State Rules on the Issue of Dominant Firms' Duty to Supply Essential Information Beyond the Requirements of Sector Regulation (BCS), E-COMPETITIONS, № 51786 (Jan. 29, 2013); Waller \& Tasch, Harmonizing Essential Facilities, supra note 233, at 747-53. 
statutes, regulations, case law, and guidelines to penalize unilateral refusals to deal and require access and interconnection. ${ }^{239}$ For example, Pakistan has explicitly referred to the U.S. essential facilities doctrine in requiring access to a stock exchange. ${ }^{240}$

The litigation over the Microsoft browser wars also produced decisions outside the United States and the EU requiring the granting of access to intellectual property rights. In Korea, the Korean Fair Trade Commission (KFTC) imposed a fine and (1) ordered Microsoft to sell in Korea a version of its Windows operating system that includes neither Windows Media Player nor Windows Messenger functionality; (2) required that Microsoft facilitate consumer downloads of third party media player and messenger products selected by the Commission; and (3) prohibited Microsoft from selling in Korea a version of its server software that includes Windows Media Services. ${ }^{241}$ The U.S. Department of Justice again criticized the KFTC decision and remedy as going "beyond what is necessary or appropriate to protect consumers, as it requires the removal of products that consumers may prefer. ${ }^{.242}$

In subsequent Microsoft disputes and matters involving other companies, China has required licensing of intellectual property rights and changes in royalty amounts in both merger and conduct cases. ${ }^{243}$ It is also worth noting that regardless of current U.S. enforcement practices, the littleused Article 40 of the TRIPs agreement of the World Trade Organization expressly permits the licensing of intellectual property rights as a remedy for violations of competition law. ${ }^{244}$

${ }^{239}$ Waller \& Tasch, Harmonizing Essential Facilities, supra note 233, at 752-58. See also JOSE

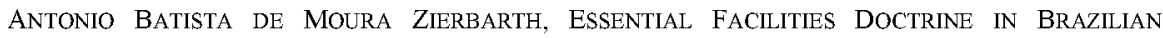
TELECOMMUNICATIONS SECTOR 21 (2010); DiRECTORATE FOR Fin. \& ENTER. AFFAIRS, COMPETITION COMM., ORg. FOR ECON. CO-OPERATION \& DEV., LATIN AMERICAN COMPETITION FORUM, COMPETITION PRINCIPLES IN ESSENTIAL FACILITIES 10 (2010).

${ }^{240}$ In re M/S Karachi Stock Exchange (Guarantee) LTD., (2007) File No. 12/ISE/Sec.3/CCP/2007, at 58-60 (Pak.), http://www.cc.gov.pk/images/Downloads/Latest\%20KSE-Order\%2029-5-09.pdf.

${ }^{241}$ ANDREW I. Gavil \& Harry First, The Microsoft Antitrust CASES: COMPETITION POLICY FOR THE TWENTY-FIRST CENTURY 230-32 (2014); Joseph Seon Hur, Analysis of the Korea Fair Trade Commission Decision on Microsoft's Tie-in Sales of Applications Programs with Windows Operating Systems, 3 COMP. L. INT'L 3, 9 (2007); Youngjin Jung, Abuse of Market Dominance in Korea: Some Reflections on the KFTC' 's Microsoft Decision, 36 LEGAL ISSUES ECON. INTEGRATION 57, 71-73 (2009).

${ }^{242}$ Press Release, U.S. Dep't of Justice, Statement of Deputy Assistant Attorney General J. Bruce McDonald Regarding Korean Fair Trade Commission's Decision in its Microsoft Case (Dec. 7, 2005), https://www.justice.gov/archive/opa/pr/2005/December/05_at_648.html.

${ }^{243}$ See generally Zhaoqi Cen, China, in The InTELLECTUAL PROPERTY AND ANTITRUst Review 23 (Thomas Vinje ed., 3d ed. 2018) (discussing IP law in China); Yee Wah Chin, Intellectual Property Rights and Antitrust in China, in IP PROTECTION IN CHINA 299 (Donna P. Suchy ed., 2015) (same).

${ }^{244}$ Agreement on Trade-Related Aspects of Intellectual Property Rights art. 40, Apr. 15, 1994, Marrakesh Agreement Establishing the World Trade Organization, Annex 1C, 1869 U.N.T.S. 299, 33 I.L.M. 1197 (1994). 
The divergence over the proper standards for single firm conduct is the most widely acknowledged of the gaps between U.S. views and the rest of the world. I now turn to what is considered the proper domain for competition law, where again the United States finds itself increasingly an outlier.

\section{THE DOMAN OF COMPETITION LAW}

The United States defines the antitrust laws as the substantive provisions of the Sherman, Clayton, and Federal Trade Commission acts along with a small number of subsidiary statutes. This limits the scope of antitrust law to agreements between competitors, monopolization law, and the review of potentially harmful mergers and acquisitions. In contrast, the EU and other jurisdictions have led the world to a broader understanding of the meaning and reach of competition law that is only partially understood or appreciated in the United States. ${ }^{245}$ This Section explores that broader vision of competition including market studies and investigations; prohibitions against public anticompetitive conduct; state aids; and the use of public interest factors normally not part of the U.S. vision of the antitrust enterprise.

\section{A. Market Studies and Market Investigations}

The competition toolkit for many jurisdictions also includes provisions for market studies in addition to specific enforcement actions. As noted by the OECD:

Market studies assess whether competition in a market is working efficiently, and identify measures to address any issues that are identified. These measures can include recommendations such as proposals for regulatory reform or improving information dissemination amongst consumers. They can also include the opening of antitrust investigations. $^{246}$

These analyses are used to identify restraints to competitions which are not limited to outright violations of existing competition laws ${ }^{247}$ and are used for competition advocacy, pre-enforcement information gathering, ex-post assessments, law reform, and the creation of new legal regimes on an industry specific basis. ${ }^{248}$

\footnotetext{
${ }^{245}$ Philip Marsden \& Spencer Weber Waller, Citizen Fox: The Global Antitrust Vision of Eleanor Fox 1-2 (Mar. 22, 2017) (unpublished manuscript), https://papers.ssrn.com/sol3/papers.cfm?abstract_id=2939336.

${ }^{246}$ Market Studies and Competition, OECD, http://www.oecd org/daf/competition/market-studiesand-competition.htm (last visited Aug. 28, 2019).

${ }^{247} \mathrm{Id}$.

${ }^{248} \mathrm{Id}$.
} 
In recent years, the OECD has held roundtable workshops, conducted surveys of past and current market studies, and worked with individual jurisdictions regarding this valuable tool of competition policy and advocacy. ${ }^{249}$ The World Bank and the International Competition Network also have been active in this area and provided financial support and technical assistance to smaller and developing jurisdictions seeking to conduct appropriate market studies in numerous industries including financial services, food retailing, and telecommunications. ${ }^{250}$

A 2016 OECD survey indicated that sixty-eight percent of jurisdictions surveyed had specific powers to undertake such surveys and another twentysix percent relied on more general competition powers to do so. ${ }^{251}$ Eightyseven percent of the respondents reported that recommendations to the government for changes in laws, regulations, or public policies were one of the potential outcomes for such inquiries. ${ }^{252}$ In some jurisdictions, the sectoral regulators have such powers either alone or in conjunction with the competition authority. ${ }^{253}$

On several occasions, the result has been the creation of a sectoral specific code of competition fine-tuned for industry characteristics and the nature of the competitive issues. One example is the United Kingdom which, after an extensive market investigation ${ }^{254}$ of the supermarket industry, created an industry code of conduct with specific rules for suppliersupermarket relations, a dispute resolution procedure, and an ombudsman. ${ }^{255}$ Similarly, Australia has specific industry codes for competition for franchising, horticulture, groceries, wheat, and oil. ${ }^{256}$ Australia also has a

\footnotetext{
${ }^{249} \mathrm{Id}$.

${ }^{250}$ ORG. FOR ECON. CO-OPERATION \& DEv., THE ROLE OF MARKET STUDIES AS A TOOL TO PROMOTE COMPETITION 4 (2016), https://one.oecd.org/document/DAF/COMP/GF(2016)4/en/pdf [hereinafter OECD MARKET STUDY SURVEY]; see also Market Studies Information Store, INT'L COMPETITION NETWORK, http://www.internationalcompetitionnetwork.org/workinggroups/current/advocacy/amsis/sectors.aspx (listing market studies by sector and jurisdiction).

${ }^{251}$ OECD MARKET STUdY SURVEY, supra note 250 , at 9.

${ }^{252} \mathrm{Id}$. at 8.

${ }^{253} I d$. at 10

${ }^{254}$ See id. at 17 (discussing the technical distinctions between market studies and market investigations).

${ }^{255}$ COMPETITION COMMISSION, SUPERMARKETS: A REPORT ON THE SUPPLy OF GROCERIES FROM MULTIPLE StORES IN THE UNITED KINGDOM, 2000 (UK), https://webarchive.nationalarchives.gov.uk/+/http:/www.competition-commission.org.uk//rep_pub/ reports/2000/446super.htm. See generally Paul W. Dobson, Exploiting Buyer Power: Lessons from the British Grocery Trade, 72 ANTITRUST L.J. 529 (2005) (providing an overview of how "increased concentration in grocery retailing in Great Britain has raised issues about the buying power of multiple retailers"). See also Press Release, Competition \& Mkt. Auth., CMA Investigates Funerals Sector (June 1, 2018) (UK), https://www.gov.uk/government/news/cma-investigates-funerals-sector (announcing most recent CMA market study).

${ }^{256}$ Franchising Code of Conduct, Competition and Consumer (Industry Codes, Franchising) Regulation 2014, made under Competition and Consumer Act 2010, reg. 168 (Austl.); Horticulture Code of Conduct, Competition and Consumer (Industry Codes, Horticulture) Regulation 2017, made under
} 
separate statutory provision permitting the creation of access provisions to designated infrastructure. ${ }^{257}$

In contrast, the United States competition agencies have more limited powers and appetite to conduct such studies and no current ability to consider whether antitrust enforcement actions or an industry specific code would be an appropriate response. The Justice Department has no statutory powers to require the production of business information outside of a specific enforcement action. This is extremely rare. In the 2016 OECD survey of sixty competition authorities, only the U.S. Justice Department and Hong Kong lacked the power to request such information. ${ }^{258}$

The Federal Trade Commission (FTC) has such powers, but chooses to use them in a more limited fashion. Section 46 of the FTC Act provides the Commission with the power to "gather and compile information concerning, and to investigate from time to time the organization, business, conduct, practices, and management of any person, partnership, or corporation engaged in or whose business affects commerce, [exempting certain industries]... and its relation to other persons, partnerships, and corporations. .259

While it is conceivable that section 46 could be used to conduct broader market studies of concentrated industries and the contemplation of industry specific antitrust rules, the FTC has not chosen to do so in recent years. Since 2006, the FTC has used section 46 to produce thoughtful reports to analyze such issues as E-cigarettes, ${ }^{260}$ cigarette and smokeless tobacco data collection, ${ }^{261}$ merger divestiture remedies, ${ }^{262}$ food and beverage marketing

Competition and Consumer Act 2010 (Aust1.); Food and Grocery Code of Conduct, Competition and Consumer (Industry Codes, Food and Grocery) Regulation 2015, made under Competition and Consumer Act 2010 (Austl.); Port Terminal Access (Bulk Wheat) Code of Conduct, Competition and Consumer (Industry Codes, Port Terminal Access (Bulk Wheat)) Regulation 2014, made under Competition and Consumer Act 2010 (Austl.); Oil Code, Competition and Consumer (Industry Codes, Oil) Regulations 2017, made under Competition and Consumer Act 2010 (Austl.).

${ }^{257}$ See generally Competition and Consumer Act 2010, (Cth) div 44AA (Austl.) (promoting "use of ... the infrastructure by which services are provided, thereby promoting effective competition in upstream and downstream markets").

${ }^{258}$ OECD MARKET STUDY SURVEY, supra note 250, at 12.

${ }^{259} 15$ U.S.C. $\$ 46($ a) $(2012)$.

${ }^{260}$ FTC Seeks Public Comments on Proposed Study of the E-Cigarette Industry (Oct. 2016), https://www.ftc.gov/system/files/documents/federal_register_notices/2016/10/161028_ecigarettes_final_30-day_frn_10-27-16gg.pdf.

${ }^{261}$ Fed. Trade Comm'n, Federal Trade Commission Cigarette Report for 2014 (2016), https://www.ftc.gov/system/files/documents/reports/federal-trade-commission-cigarette-report-2014federal-trade-commission-smokeless-tobacco-report/ftc_cigarette_report_2014.pdf (last visited Aug. 19,

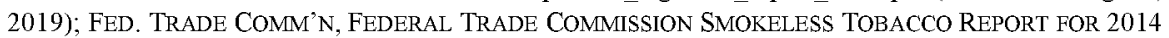
(2016), https://www.ftc.gov/system/files/documents/reports/federal-trade-commission-cigarette-report2014-federal-trade-commission-smokeless-tobacco-report/ftc_smokeless_tobacco_report_2014.pdf (last visited Aug. 19, 2019).

${ }^{262}$ Remedy Study, FED. TRADE COMM'N, https://www.ftc.gov/policy/studies/remedy-study (last visited Aug. 19, 2019). 
to children, ${ }^{263}$ homeowners insurance, ${ }^{264}$ automobile insurance, ${ }^{265}$ alcoholic beverage advertising, ${ }^{266}$ patent assertion entities, ${ }^{267}$ generic drugs, ${ }^{268}$ consumer fraud, ${ }^{269}$ and data sharing practices among corporate affiliates. ${ }^{270}$

This list includes numerous important consumer protection matters and certain competition issues that cut across industry lines (patent trolls and merger remedies $)^{271}$ but only one specific competition-related study of a particular industry (generic drugs) ${ }^{272}$ This valuable study included proposals for legislative reform for vexing problems with the gaming of the system for the introduction and approval of generic drugs. ${ }^{273}$

The United States' experience with sector specific antitrust codes is largely limited to the 1921 Packer and Stockyard Act $^{274}$ which was enacted because of Progressive Era concerns with the imbalance of power between small livestock producers as sellers and the large concentrated (and often colluding) meat packers as buyers. Even here, government failure to update the regulations under this act for modern times and judicial reinterpretation of the Act to more closely track the general antitrust laws has made this

${ }^{263}$ Food Marketing to Children and Adolescents, FED. TRADE COMM'N, https://www.ftc.gov/foodmarketing-to-children-and-adolescents (last visited Aug. 19, 2019).

${ }^{264}$ FTC Orders Nine Insurers to Submit Information for Study of the Effect of Credit-Based Insurance Scores on Consumers of Homeowners Insurance, FED. TRADE COMM'N (Dec. 23, 2008), https:/Www.ftc.gov/news-events/press-releases/2008/12/ftc-orders-nine-insurers-submit-informationstudy-effect-credit.

${ }^{265}$ Fed. Trade COMm'N, Credit-Based Insurance Scores: Impacts on Consumers of AUtOMOBILE INSURANCE: A REPORT to CONGRESS BY THE FEDERAL TRADE COMMISSION (2007), https://www.ftc.gov/sites/default/files/documents/reports/credit-based-insurance-scores-impactsconsumers-antomobile-insurance-report-congress-federal-trade/p044804facta_report_creditbased_insurance_scores.pdf.

${ }^{266}$ Fed. Trade COMm'N, Self-Regulation in the Alcohol Industry: Report of the FEDERAL TRADE COMMISSION (2014), https://www.ftc.gov/system/files/documents/reports/selfregulation-alcohol-industry-report-federal-trade-commission/140320alcoholreport.pdf.

${ }^{267}$ Fed. Trade Comm'N, Patent Assertion Entity ACtivity: An FTC Study (2016), https:/www.ftc.gov/system/files/documents/reports/patent-assertion-entity-activity-ftcstudy/p131203_patent_assertion_entity_activity_an_ftc_study_0.pdf [hereinafter FTC PATENT ASSERTION STUDY].

${ }^{268}$ FED. TRADE COMM'N, AUTHORIZEd GENERIC DRUGS: SHORT-TERM EFFECTS AND LONG-TERM IMPACT (2011), https://WwW.ftc.gov/sites/default/files/documents/reports/authorized-generic-drugsshort-term-effects-and-long-term-impact-report-federal-trade-commission/authorized-generic-drugsshort-term-effects-and-long-term-impact-report-federal-trade-commission.pdf.

${ }^{269}$ Notice, 81 Fed. Reg. 234 (Dec. 6, 2016).

${ }^{270}$ Notice and Request for Comment, 76 Fed. Reg. 17 (Jan. 26, 2011)

${ }^{271}$ FTC PATENT ASSERTION STUDY, supra note 267.

${ }^{272}$ FED. TRAde COMM'N, GENERIC DRUG ENTRy PRIOR TO PATENT EXPIRATION: AN FTC STUDY (2002), https://www.ftc.gov/sites/default/files/documents/reports/generic-drug-entry-prior-patentexpiration-ftc-study/genericdrugstudy_0.pdf.

${ }^{273} I d$. at $\mathrm{i}-\mathrm{xi}$.

${ }^{274} 7$ U.S.C. $\$ 181-229 b(2012)$. 
experiment a highly criticized and mostly ineffective tool to achieve its intended purpose. ${ }^{275}$

\section{B. Competition and the Public Sector}

The United States tends to view antitrust law as a narrow and specialized field applying only to private economic activity. U.S. antitrust does not reach most restraints on competition imposed by the federal, state, or local government. Restraints on competition imposed by the U.S. Congress are immune from the antitrust law so long as the intent of Congress is clear to achieve some result at odds with the baseline rules of the antitrust laws. ${ }^{276}$

Restraints by state governments are immune from the antitrust law under the antitrust "state action" doctrine where the state has clearly articulated a policy of something other than the competition otherwise mandated by the federal antitrust laws. ${ }^{277}$ The Supreme Court justified this sweeping judicially-created exception to the antitrust laws on the grounds that the Sherman and Clayton acts were intended to regulate private market conduct, and not sovereign state government. ${ }^{278}$ To do otherwise also would raise important federalism concerns under the Constitution. ${ }^{279}$

Anticompetitive private conduct pursuant to immune state action would also be protected so long as the state further actively supervised the private conduct in question. ${ }^{280}$ Otherwise unlawful local government action would be similarly protected if the local government had been delegated the power to regulate the activity in question by the state through constitutional, legislative, or judicial decision. ${ }^{281}$ Moreover, local governments are immune from most damage awards under the antitrust laws, and are only subject to prospective injunctive relief. ${ }^{282}$

The domain of competition law is substantially broader outside the United States. From its inception, the EU has applied its competition law to the public sector and private firms receiving special privileges from the state, rather than shielding such firms as in the United States.

275 Peter C. CARstensen, Competition Policy and the Control of Buyer Power: A GLOBAL ISSUE 143 (2017) ("The PSA in the United States illustrates the challenges that less-thantransparent standards create."); Peter C. Carstensen, The Packers and Stockyards Act: A History of Failure to Date, CPI ANTITRUsT J., Apr. 2010, at 2; Roger A. McEowen et al., The 2002 Senate Farm Bill: The Ban on Packer Ownership of Livestock, 7 DRAKE J. AGRIC. L. 267, 271 (2002).

${ }^{276}$ Dolan v. U.S. Postal Serv., 546 U.S. 481, 481-82 (2006) ("Congress intended to retain immunity only for injuries arising because mail either fails to arrive or arrives late, . . or at the wrong address, since such harms are primarily identified with the Postal Service's function of transporting mail.").

${ }^{277}$ Parker v. Brown, 317 U.S. 341, 363 (1943)

${ }^{278} \mathrm{Id}$. at $350-51$

${ }^{279} \mathrm{Id}$. at 352 .

${ }^{280}$ N.C. State Bd. of Dental Exam'rs v. FTC, 135 S. Ct. 1101, 1117 (2015).

${ }^{281}$ Cmty. Commc'ns Co. v. City of Boulder, 455 U.S. 40, 51 (1982).

${ }^{282}$ Local Government Antitrust Act of 1984, Pub. L. No. 98-544, 98 Stat. 2750 (1984) (codified at 15 U.S.C. $\S \S 34-36$ ). 
This decision relates to a combination of factors. These include the historically larger role of the public sector in most of the member states, the legacy of state enterprises in the former socialist Eastern European member states, and the existence of numerous privatized undertakings that still enjoyed a dominant position through their control of formerly public infrastructure.

Article 106 of the TFEU sets forth the ground rules for the application of the EU competition rules to public enterprises and private undertaking enjoying special privileges. It states:

1. In the case of public undertakings and undertakings to which Member States grant special or exclusive rights, Member States shall neither enact nor maintain in force any measure contrary to the rules contained in the Treaties, in particular to those rules provided for in Article 18 and Articles 101 to 109 [the competition rules].

2. Undertakings entrusted with the operation of services of general economic interest or having the character of a revenueproducing monopoly shall be subject to the rules contained in the Treaties, in particular to the rules on competition, in so far as the application of such rules does not obstruct the performance, in law or in fact, of the particular tasks assigned to them. The development of trade must not be affected to such an extent as would be contrary to the interests of the Union.

3. The Commission shall ensure the application of the provisions of this Article and shall, where necessary, address appropriate directives or decisions to Member States. ${ }^{283}$

These rules are vigorously enforced by the Commission and the ECJ. ${ }^{284}$ The EU Commission has also enacted a number of regulations under Article 106(3) to affirmatively facilitate competition in industries such as telecommunications and other forms of infrastructure. ${ }^{285}$

C. State Aids as Competition Law

The EU rules on state aids as part of competition law are equally unfamiliar in the U.S. context. Article 107 of the TFEU states:

\footnotetext{
${ }^{283}$ TFEU art. 106.

${ }^{284}$ See Case T-169/08, Dimosia Epicheirisi Ilektrismou AE (DEI) v. Comm'n, [2016] 4 C.M.L.R. 26,233-39 (finding violation of Article 106 regarding operation of electrical utility). See generally ARIEL EzRachi, EU COMPETITION LAW: An Analytical Guide to the Leading Cases (6th ed. 2018) (collecting cases).

${ }^{285}$ See generally 2 SPEnCER WEBER WaLler \& ANDre FIEBIG, ANTITRUST AND AMERICAN BUSINESS ABROAD $§ 17.08$ (4th ed. 2019).
} 
Save as otherwise provided in the Treaties, any aid granted by a Member State or through State resources in any form whatsoever which distorts or threatens to distort competition by favouring certain undertakings or the production of certain goods shall, in so far as it affects trade between Member States, be incompatible with the internal market. ${ }^{286}$

The treaty spells out certain automatic and discretionary exceptions to permit member states to address poverty, regional economic development, environmental concerns, and other social needs that are not likely to distort competition within the EU ${ }^{287}$ The EU Commission reviews all state aids in conjunction with the member states.

If, after giving notice to the parties concerned to submit their comments, the Commission finds that aid granted by a State or through State resources is not compatible with the internal market ... or or that such aid is being misused, it shall decide that the State concerned shall abolish or alter such aid within a period of time to be determined by the Commission. ${ }^{288}$

Regulations can be adopted by the Commission, and exemptions can be adopted through a proposal of the Commission and granted by the Council of Ministers in consultation with the European Parliament. ${ }^{289}$

A vast and complicated jurisprudence has arisen as to when and how state aids to undertakings are incompatible with the provisions of Article 107. At the risk of oversimplifying, state aids are unlawful if they provide benefits on terms more favorable than the undertaking could obtain in the private sector. ${ }^{290}$ This can apply to outright grants, below market loans or other financing, tax concessions, or any other tangible benefit on below market terms. State aids found to be incompatible with the common market are required to be clawed back by the member state from the recipient. One recent example is the EU Commission's controversial decision that tax concessions granted to Apple by the Republic of Ireland were incompatible with the common market and capable of distorting competition. ${ }^{291}$ Other

\footnotetext{
286 TFEU art. 107.

${ }^{287} I d$. art. $107(2),(3)$.

${ }^{288} \mathrm{Id}$. art. $108(2)$

${ }^{289} \mathrm{Id}$. art. 109.

${ }^{290}$ PIET JAN SLOT \& MARTIN FARLEY, AN INTRODUCTION TO COMPETITION LAW 265-67 (2d ed. 2017). See generally EU STATE AID CONTROL: LAW AND ECONOMICS (Philipp Werner \& Vincent Verouden eds., 2016) (discussing when State aids distort competition); CONOR QUIGLEY, EUROPEAN State Aid LAW AND Policy (3d ed. 2015); Diheng Xu, Rationale Behind State Aid Control Over Tax Incentives, 41 WORLD COMP. L. \& ECON. REV. 255, 255 (2018) (highlighting how "distortion of competition is forbidden, since, if certain economic participants are favoured unfairly by State aid measures, the level playing field may be at risk").

${ }^{291}$ Commission Decision 2017/1283/EC, SA.38373 (2014/C) (ex 2014/NN) (ex 2014/CP) implemented by Ireland to Apple, 2016 O.J. (L 187) 1, 52-53, 109.
} 
pending state aid investigations and decisions relating to tax concessions focus on Amazon and Starbucks, among other U.S. corporations. ${ }^{292}$

Certain EU member states also have their own national state aids provisions. Countries like Ukraine are obliged to enforce state aids provisions as part of preferential trade agreements with the EU. ${ }^{293}$ Ironically, the United Kingdom does not currently have state aids as part of the CMA's competition toolkit but will be adopting such provisions as part of the Brexit process along with a significant increase in its staff to enforce these provisions. $^{294}$

Outside the EU, there is a wide mixture of practices as to state aids as part of the competition toolbox. State aids provisions are most common in regional trade agreements to ensure competitive neutrality among members of the trading bloc. ${ }^{295}$ Other jurisdictions bar state aids which affect competitive neutrality within their national economies. ${ }^{296}$

The United States simply lacks this important tool. As a result, states vigorously compete with each other to provide incentives to lure or retain businesses within their territory usually to the net detriment of the taxpayers of that state. ${ }^{297}$

\section{Public Interest Factors}

Statutes providing a national government, ministry, or competition agency the explicit power to sacrifice competition for national security, employment, or some other significant public interest are common outside the United States. Such "public interest" overrides are most common in merger review, but certain jurisdictions have such provisions for anticompetitive agreements and/or abuse of dominance cases as well.

\footnotetext{
${ }^{292}$ U.S. DEP'T OF TREASURY, THE EUROPEAN COMMISSION'S RECENT STATE AID INVESTIGATIONS OF TRANSFER PRICING RULES 2 (2016), https://www.treasury.gov/resource-center/taxpolicy/treaties/Documents/White-Paper-State-Aid.pdf; Amedeo Arena, State Aids and Tax Rulings: An Assessment of the Commission's Recent Decisional Practice, 1 MKt. \& COMPETITION L. Rev. 49, 54 (2017).

${ }^{293}$ ORG. FOR ECON. CO-OPERATION \& DEV., OECD REVIEWS OF COMPETITION LAW AND POLICY UKRAINE 14 (2016), http:/www.oecd.org/daf/competition/UKRAINE-OECD-Reviews-of-CompetitionLaw-and-Policy_WEBENG.pdf; Getting the Deal Through: State Aid 2016. Ukraine, AsTERS (Aug. 31, 2016), https://www.asterslaw.com/ru/press_center/news/state_aid_ukraine/.

${ }^{294}$ Oborne Clark, How Will State Aid Be Regulated in the UK in the Event of a No Deal Brexit?, LEXOLOGY (Feb. 4, 2019), https://www.lexology .com/library/detail.aspx?g=186a4a3c-b95b-46f8-969534d562966d94.

${ }^{295}$ See Bernard HoEkMan, World Bank Ctr. For ECON. POlicy RESEARCh, COMPETITION $\begin{array}{lllll}\text { POLICY AND PREFERENTIAL TRADE AGREEMENTS } 6 & \text { (2002), }\end{array}$ http://web.worldbank.org/archive/website01006/WEB/IMAGES/WBI37131.PDF (discussing state aid provisions in the EEA, the EU Association, and free trade agreements).

${ }^{296}$ Org. for ECON. Co-Operation \& Dev., POlicy Roundtable on COMPetition, State Aid, AND SUBSIDIES 10 (2010).

${ }^{297}$ Mark Strassmann, Amazon HQ2: 20 Finalists Competing to Host New Headquarters, CBS NEws (Jan. 18, 2018, 6:46 PM), https://www.cbsnews.com/news/amazon-hq2-20-finalists-competingto-host-new-headquarters/.
} 
The EU has a provision that has been used for public interest purposes in the past. Article 101(3) of the TFEU provides:

The provisions of [Article 101(1)] may, however, be declared inapplicable in the case of:

- any agreement or category of agreements between undertakings,

- any decision or category of decisions by associations of undertakings,

- any concerted practice or category of concerted practices, which contributes to improving the production or distribution of goods or to promoting technical or economic progress, while allowing consumers a fair share of the resulting benefit, and which does not:

(a) impose on the undertakings concerned restrictions which are not indispensable to the attainment of these objectives;

(b) afford such undertakings the possibility of eliminating competition in respect of a substantial part of the products in question. ${ }^{298}$

This provision has been used to exempt otherwise anticompetitive agreements which violated Article 101(3) in order to validate so-called crisis cartels, deal with the Arab oil embargo, promote environmental goals, and deal with other public interest factors that go beyond the effect of an agreement on competition. ${ }^{299}$ While Article 101(3) is rarely used recently in this manner, it remains a potent weapon for future court cases and decisions of national competition authorities.

Numerous jurisdictions have public interest standards in their merger laws allowing the approval or rejection of transactions on grounds other than their competitive effects. ${ }^{300}$ One of the most prominent is the Republic of South Africa, which introduced the modern form of its competition law in 1998 as part of the post-apartheid legal and political regime. ${ }^{301}$

\footnotetext{
${ }^{298}$ TFEU art. 101(3); see also id. art. 346 (addressing national security).

${ }^{299} 2$ WALLER \& FIEBIG, supra note 285, ch. 17; RICHARD WHISH \& DAVID BALEY, COMPETITION LAW 166-68 (Oxford Univ. Press 9th ed. 2018); Andre Fiebig, Crisis Cartels and the Triumph of Industrial Policy Over Competition Law in Europe, 25 BROOK. J. INT'L L. 607, 622-23 (1999).

${ }^{306}$ DiRECTORATE FOR FIN. \& ENTER. AFFAIRS, COMPETITION CO., ORG. FOR ECON. CO-OPERATION \& DEV., SUMMARY OF DisCuSSION OF THE ROUNDTABLE ON PUBliC INTEREST CONSIDERATIONS IN MERGER CONTROL 2 (2017), https://one.oecd.org/document/DAF/COMP/WP3/M(2016)1/ANN4/FINAL/en/pdf

${ }^{301}$ See Guidelines on the Assessment of Public Interest Provisions in the Merger Regulation Under the Competition Act No. 89 of 1998, GN 309 of GG 40039 (2 June 2016), http:/www.compcom.co.za/wp-content/uploads/2016/01/Gov-Gazette-Public-Interest-Guidlines.pdf ("These guidelines seek to provide guidance regarding the Commission's approach to analyzing mergers by indicating the approach that the Commission is likely to follow and the types of information that the Commission may require when evaluating public interest grounds ....").
} 
The economic empowerment of the previously oppressed black majority population was a critical goal of the competition regime. ${ }^{302}$ As a result, the South African merger regime permits anticompetitive mergers to be approved on specified public interest grounds. ${ }^{303}$ The law also permits the denial on public interest grounds of mergers that are otherwise innocuous with respect to competition. ${ }^{304}$

In addition to the effect on competition, the South African merger regime also requires consideration of the merger's effect on:

1) A particular industrial sector or region;

2) Employment;

3) The ability of small businesses or firms controlled by black persons to become competitive; and

4) The ability of national industries to compete in international markets. ${ }^{305}$

The South African Competition Commission has issued guidelines to implement this additional facet of their merger control regime, ${ }^{306}$ and the competition tribunal has applied the statute and guidelines in key case law. ${ }^{307}$ Similar public interest standards exist in such diverse competition regimes as Malawi and New Zealand, and are often a key component of the political support behind the enactment of competition law in the first place in such jurisdictions. ${ }^{308}$

U.S. statutes and case law do not permit the consideration of such general social welfare factors in an antitrust case. In the Professional Engineers case, the U.S. Supreme Court summarily rejected the defendant's proposed affirmative defense that the competitive bidding process for public

\footnotetext{
${ }^{302}$ ORG. FOR ECON. CO-OPERATION \& DEV., COMPETITION LAW AND POLICY IN SOUTH AFRICA: $\begin{array}{lllllll}\text { AN OECD } & \text { PEER } & \text { REVIEW } & 3-4, & 7, & 9 & \text { (2003), }\end{array}$ https:/www.oecd org/daf/competition/prosecutionandlawenforcement/2958714.pdf.

${ }^{306}$ Guidelines on the Assessment of Public Interest Provisions in the Merger Regulation Under the Competition Act No. 89 of 1998, GN 309 of GG 40039 (2 June 2016), http://www.compcom.co.za/wpcontent/uploads/2016/01/Gov-Gazette-Public-Interest-Guidlines.pdf.

${ }^{307}$ In the large merger between Shell South Africa (Pty) Ltd. and Tepco Petroleum (Pty) Ltd. 2002 1 (Tribunal)at 9 para. 36 (S. Afr.); Minister of Econ. Dev. \& Others v. Competition Tribunal \& Others, S. African Commercial, Catering \& Allied Workers Union (SACCAWU) v. Wal-Mart Stores Inc. \& Another 20121 (ZACAC 2) at 8 para. 11, 69 para. 110, 111 (S. Afr.). See also Michael-James Currie, South Africa Competition Tribunal: Merging Parties Penalised for Failure to Comply with Public Interest Conditions, AFRICAN ANTITRUST \& COMPETITION L., https://africanantitnust.com/2018/07/03/south-africa-competition-tribunal-merging-parties-penalisedfor-failure-to-comply-with-public-interest-conditions/amp/? _twitter_impression=true (last accessed Aug. 17, 2019) (penalizing merging parties for not complying with monitoring conditions of post-merger employment)

308 Competition \& Fair Trading Act 1998, $\$ \S \quad 35-38$ (Malawi), http://www.wipo.int/edocs/lexdocs/laws/en/mw/mw003en.pdf; Commerce Act 1986, s 3A (N.Z.).
} 
works could produce a threat to public safety in the form of shoddy engineering work by unscrupulous engineers making unrealistic low ball bids and potentially using substandard materials or construction techniques. ${ }^{309}$ This could be true in particular instances, but it was legally irrelevant to the court. ${ }^{310}$ It was legally irrelevant as well in earlier cases (1) that competition might not be an appropriate public policy for certain industries or (2) that the defendants in fact agreed upon a reasonable price. ${ }^{311}$

Similarly, the United States does not have public interest standards incorporated into its merger laws. Section 7 of the Clayton Act prohibits those mergers and acquisitions which may tend to substantially lessen competition or may tend to create a monopoly. ${ }^{312}$ The Horizontal Merger Guidelines and the limited modern case law do not allow for consideration of other important social factors such as employment, economic development, environmental effects, racial justice, or other public factors in the analysis of the competitive effects of a proposed or consummated transaction. ${ }^{313}$ While certain commentators have advocated for more explicit use of public interest standards in U.S. antitrust policy more generally and in merger policy in particular, ${ }^{314}$ change in this direction seems unlikely for the foreseeable future.

While the United States does not have public interest standards in its merger regime, certain mergers in regulated industries may be subject to approval by sectoral regulators that do have explicit "public interest" powers. One prominent example is the Federal Communication Commission, which must consider the effect on both competition and the public interest in considering a media merger subject to its jurisdiction. ${ }^{315}$ Similarly, the banking agencies may also consider the broader public interest in addition to competitive effects in considering a merger or acquisition within their jurisdiction. ${ }^{316}$

\footnotetext{
${ }^{309}$ Nat'1 Soc'y of Prof'l Eng'rs v. United States, 435 U.S. 679, 684-85, 692 (1978)

${ }^{310} I d$. at 692

${ }^{311}$ United States v. Trenton Potteries Co., 273 U.S. 392, 397-98 (1927); United States v. Addyston Pipe \& Steel Co., 85 F. 271, 283-87, 293 (6th Cir. 1898), aff'd, 175 U.S. 211 (1899); United States v. Trans-Missouri Freight Ass'n, 166 U.S. 290, 320-27 (1897).

${ }^{312}$ Clayton Act, 15 U.S.C. $\$ 18$ (2012).

${ }^{313}$ See U.S. DeP'T OF JuSTICE \& FED. TRAdE COMM'N, HorizonTAl MERger Guidelines (2010), https://www.ftc.gov/sites/default/files/attachments/merger-review/100819hmg.pdf (providing guidelines on how the agencies determine anticompetitive behavior with no mention of examining important social factors such as employment, economic development, environmental effects, and racial justice).

314 See generally MAURICE E. STUCKE \& ARIEL EZRACHI, COMPETITION OVERDOSE (forthcoming Mar. 17, 2020) (using examples to illustrate how society overprescribed competition as a solution); Richard Bunell, The Social Costs of Mergers: Restoring Local Control as a Factor in Merger Policy, 85 N.C. L. REV. 149 (2006) (maintaining that "the loss of local control should be restored as a factor in merger policy").

${ }^{315}$ Federal Trade Commission Act, 15 U.S.C. $\$ 45$ (2012)

${ }^{316}$ Federal Deposit Insurance Act, 12 U.S.C. $\S 1828(\mathrm{c})(5)(\mathrm{B})(2012)$.
} 
The United States also has rarely used statutes allowing non-competition factors to supersede competitive analysis to achieve national security objectives. Mergers may be blocked on national security grounds even if cleared by the competition agencies. ${ }^{317}$ In addition, the Defense Production Act of 1950 (DPA) allows the President to exempt agreements between private parties from the application of the antitrust laws where such action was taken for the national defense. ${ }^{318}$

It is important to note that even in the limited situations where a broader public interest is applied, such a process is assigned outside of the competition agencies. This is in marked contrast to the practice of jurisdictions such as South Africa and elsewhere where the competition agencies and tribunals integrate both competition and public interest criteria into the analysis of a particular transaction or practice.

\section{ENFORCEMENT STRUCTURES}

While there are a wide diversity of public agency structures for the competition law enforcement, the United States sticks out like a bit of a sore thumb. The United States has a unique system of two partially overlapping agencies: the FTC, which has jurisdiction over both competition and consumer cases, and the Antitrust Division of the Justice Department, which investigates and brings only competition cases. ${ }^{319}$ The FTC has jurisdiction over the civil enforcement of competition cases, while the Antitrust Division has both civil and criminal enforcement powers and is the sole enforcer of criminal antitrust cases. ${ }^{320}$ The Antitrust Division has authority to bring cases under the Sherman Act and Clayton Act, while the FTC brings its actions under section 5 of the FTC Act, which prohibits "unfair methods of competition." 321 Section 5 of the FTC Act has been interpreted to cover all violations of the Sherman and Clayton acts as well as a vague penumbra of unfair practices that consist of incipient violations of the antitrust laws or violations of the spirit of those provisions. ${ }^{322}$

The Antitrust Division of the Justice Department brings its cases in federal court before the United States District Court that has personal jurisdiction and venue over the defendants charged with a civil or criminal

\footnotetext{
${ }^{317}$ Defense Production Act of 1950, 50 U.S.C. $\S 4565(b)(4)$ (A), (d) (2012).

31850 U.S.C. $\$ \$ 4558(\mathrm{j}), 4565$ (d) (2012).

319 Guide to Antitrust Laws: The Enforcers, FED. TRADE COMMISSION, https://www.ftc.gov/tipsadvice/competition-guidance/guide-antitrust-laws/enforcers (last visited Aug. 25, 2019). 
antitrust violation. The U.S. FTC brings most of its merger cases directly in federal district court in the same manner. ${ }^{323}$ The FTC also brings certain cases through an internal administrative procedure where the losing respondent can appeal to the relevant appellate court. ${ }^{324}$ To make matters more confusing, the standards for a preliminary injunction in a merger case in administrative FTC litigation are slightly different from the standards in federal district court. There is pending legislation that would harmonize the two standards in favor of the more stringent district court standards.$^{325}$

While the two agencies have similar enforcement powers in civil antitrust matters, they have different origins and structures. The Antitrust Division is part of the U.S. Justice Department, itself part of the Executive Branch. ${ }^{326}$ The head of the Antitrust Division holds the title of an Assistant Attorney General, is selected by the Attorney General with the concurrence of the President, and is subject to confirmation by the U.S. Senate. ${ }^{327}$ The Deputy Assistant Attorneys General in charge of the various operating sections of the Antitrust Division are selected by the head of the Antitrust Division and are also subject to Senate confirmation. ${ }^{328}$

In contrast, the Federal Trade Commission is an independent federal agency subject to the Administrative Procedures Act, ${ }^{329}$ the Sunshine in Government Act, ${ }^{330}$ and other legal constraints similar to the plethora of other administrative agencies in the federal government. The FTC is headed by five presidentially appointed commissioners, no more than three of which can be members of the same party as the President. ${ }^{331}$ Each commissioner is subject to Senate confirmation and may not be removed from office during their seven-year term except for good cause. ${ }^{332}$

This means that the United States has two strikingly similar agencies, one subject to the normal constraints of administrative law and the other not, despite a substantial overlap of function. ${ }^{333}$ The two agencies consult informally with each other to assign all new investigations and merger

\footnotetext{
${ }^{323} 15$ U.S.C. $\$ 53($ a) (2012).

${ }^{324}$ 16 C.F.R. $\$ 3.52$ (2018)

${ }^{325}$ Standard Merger and Acquisition Reviews Through Equal Rules Act of 2018, H.R. 5645, 115th Cong. $\$ 2$ (2018); S. 2847, 115 th Cong. (2018).

326 Organization, Mission and Functions Manual: Antitrust Division, U.S. DEP'T JUsT., https://www.justice.gov/jmd/organization-mission-and-functions-manual-antitrust-division (last visited Aug. 27, 2019).

${ }^{327}$ Assistant Attorney General, U.S. DEP'T JUST., https://www.justice.gov/atr/assistant-attorneygeneral (last visited Aug. 27, 2019).

${ }^{328} 28$ U.S.C. $\$ 506(2012)$

${ }^{329}$ Administrative Procedures Act, 5 U.S.C. $\$ \S 500-96$ (1946).

${ }^{330}$ Government in the Sunshine Act, 5 U.S.C. $\$ 552 b$ (1976).

${ }^{331} 15$ U.S.C. $\$ 41(1950)$.

${ }^{332}$ Humphrey's Ex'r v. United States, 295 U.S. 602, 602 (1935)

333 Spencer Weber Waller, Prosecution by Regulation: The Changing Nature of Antitrust Enforcement, 77 OR. L. REV. 1383, 1387 (1998).
} 
reviews so only one agency will investigate any individual matter, but Congress blocked formalizing such arrangements. ${ }^{334}$ While both agencies view their mission as law enforcement, they each undertake a large number of similar more regulatory functions such as issuing guidelines and advisory opinions, engaging in competition advocacy, conducting research, presenting workshops, participating in interagency decision making, and representing the United States in various international organizations, consultations, and negotiations. Not surprisingly, this unique situation has led to numerous proposals to unify competition enforcement within a single agency with some favoring consolidation in the FTC and others in the Justice Department. ${ }^{335}$

It is more than just the dual nature of federal antitrust enforcement that distinguishes the United States from the rest of the world. In the past, both Brazil and China have had more than one competition law enforcer, but Brazil has recently consolidated enforcement in a single agency and China is in the process of doing so. ${ }^{336}$

Nor is it the main issue whether to combine competition and consumer protection within one agency or split them between two specialist agencies. There is no single right answer on this important question of institutional design upon which reasonable people can differ ${ }^{337}$ Over time, competition agencies have added and shed related consumer protection jurisdiction, and strong arguments can be made in favor of each model. ${ }^{338}$

334 Justin O'Neill Kay, Clearance: The Back Story and Looking Forward, ANTITRUST SOURCE, Aug. 2012, at 12; FTC and DOJ Announce New Clearance Procedures for Antitrust Matters: Memorandum of Agreement Allocates Industry Sectors Between Agencies, FED. TRADE COMMISSION (Mar. 5, 2002), https://www.ftc.gov/news-events/press-releases/2002/03/ftc-and-doj-announce-newclearance-procedures-antitrust-matters.

335 Darren Bush, Out of the DOJ Ashes Rises the FTC Phoenix: How to Enhance Antitrust Enforcement by Eliminating an Antitrust Enforcement Agency, 53 WILLAMETTE L. REV. 33, 52 (2016); Waller, supra note 333; Ernest Gellhorn et al., Has Antitrust Outgrown Dual Enforcement? A Proposal for Rationalization, 3 ANTITRUST BULL. 695, 702 (1990).

${ }^{336}$ Decreto No. 12.529 , de 30 de Novembro de 2011, Diário OfiClal DA União [D.O.U.] de 5.2012 (Braz.) (structuring the Brazilian System for Protection of Competition and setting forth preventive measures and sanctions for violations against the economic order); see also ANA PAULA MARTINEZ \& MARIANA TAVERES DE ARAUJo, OVERVIEW OF COMPETITION LAW IN BRAZIL 257-58 (Cristianne Zarzur et al. eds., 2015) (explaining the current structure of Brazil's competition law); Adrian Emch, China to Merge Antitrust Authorities, KLuwer COMPETITION L. BLOG (Mar. 21, 2018), http:/competitionlawblog.kluwercompetitionlaw.com/2018/03/21/china-merge-antitrust-authorities/ (discussing Chinese antitrust authorities).

${ }^{337}$ See generally Symposium, A Comparative Analysis of Antitrust Law Regimes: Designing Better Institutions for Deciding Antitrust Issues, 41 LoY. U. CHI. L.J. 411 (2010) (discussing multiple viewpoints on this issue); Spencer W. Waller, Antitrust Marathon $V$ : With Authority, 6 EUR. COMP. J. 1 (2010) (same)

${ }^{338}$ ORg. FOR ECON. CO-OPERATION \& DEV., OECD POLICY ROUNDTABles: THE INTERFACE BETWEEN COMPETITION AND CONSUMER POLICIES 10 (2008), http:/www.oecd.org/regreform/sectors/40898016.pdf (executive summary of debate regarding the interface between competition and consumer policies and the ideal institutional design of competition 
It is rather the center of decision authority that is the most important difference between the United States and the rest of the world. The U.S. system is primarily, but not exclusively, court based with the competition agencies having to investigate a case with the goal of proving its case before its independent federal district court judge enjoying life tenure and other attributes of constitutionally guaranteed judicial independence. ${ }^{339}$

The U.S. agencies are first and foremost litigators having to prove their cases before generalist judges in federal court to prevail. The Department of Justice must bring all of its cases, both criminal and civil, in federal district court. In civil cases, it is subject to the same rules of procedure and evidence and the same burdens of pleadings, production, and proof as any other litigant. The same is true for any merger case brought by the Federal Trade Commission. In criminal cases, the Department of Justice is subject to the same federal rules of criminal procedure and federal rules of evidence and has the higher burden of proof beyond a reasonable doubt.

This is in marked difference to the agency-centered model in most other jurisdictions. In the EU and most member states, the competition agency combines most, if not all, functions of investigation, litigation, adjudication, and determination of remedy. This is true for mergers, abuse of dominance, and most conduct cases, even those imposing extraordinarily large civil or administrative fines. This has led to a broad body of criticism of such agencies acting as prosecutor, judge, jury, and executioner in the same case and calls for greater separation of functions and greater use of independent hearing officers and other reforms. ${ }^{340}$ Only the rare purely criminal case outside the United States would be brought in the general court systems. ${ }^{341}$

These differences between the agency-centered and court based models are also reflected in the nature of judicial review in the United States and abroad. The losing party in a federal district court trial may appeal a final judgment to the appropriate federal circuit court of appeals and if unsuccessful seek discretionary review in the United States Supreme

\footnotetext{
policy); Directorate for Fin. \& Enter. Affairs, Competition COMm., Org. for ECON. CoOPERATION \& DEV., SUMMARY RECORD: ANNEX to tHE SUMMARY RECORD OF THE 123RD MEETING OF THE COMPETITION COMMTTTEE HELD ON 15-19 JUNE 2015, at 2 (2015), http://www.oecd.org/officialdocuments/publicdisplaydocumentpdf/?cote=DAF/COMP/M(2015)1/ANN 9/FINAL\&docLanguage $=$ En (describing the "key points of the roundtables on changes in institutional design"); Model Law on Competition (2015) - Revised Chapter VIII, 6-7, ICN, U.N. Doc. TD/RBF/CONF.8/L.3, (May 21, 2015), http://unctad.org/meetings/en/SessionalDocuments/tdrbpconf813_en.pdf.

${ }^{339}$ U.S. ConsT. art. III

${ }^{340}$ Maciej Bernatt, McWane and Judicial Review of Federal Trade Commission Decisions: Any Inspirations for EU Competition Law?, 38 EUR. COMPETITION L. REV. 288, 289 (2017).

${ }^{341}$ In civil administrative FTC matters, the procedure is somewhat closer to the agency model, but important safeguards exist along with separation of function between the agency staff investigating and ligating cases and the commissioners adjudicating them. 1 STEPHANIE KANWIT, FEDERAL TRAdE COMMISSION $\S 8.3$ (2018 ed.).
} 
Court. ${ }^{342}$ Factual findings by juries or by judges in bench trials are subject to limited appellate review, but rulings of law are subject to de novo review on appeal. ${ }^{343}$ The limited number of FTC administrative decisions in the competition area are appealable by a losing respondent to the federal court of appeals, and its factual findings and mixed findings of law and fact normally are granted a measure of discretion and upheld if supported by substantial evidence. ${ }^{344}$

Judicial review is a fundamental aspect of due process and is present in virtually every legal system, but it often proceeds very differently than in the United States. The EU system is a common system often replicated in member states and other jurisdictions. The respondent may appeal an adverse decision from the European Commission, an integrated agency, to the General Court and then the Court of Justice. However, the General Court grants substantial deference to the agency's determination of the application of law and economics to the facts of the case ${ }^{345}$ In the EU, this is referred to as the margin of discretion for complex economic evaluations. ${ }^{346}$ The ECJ's jurisdiction is then limited to matters of law. The combination of an integrated agency structure, hefty fines, and lack of full de novo appellate review has led to criticisms of violations of fundamental notions of due process and human rights in such systems. ${ }^{347}$ These concerns are amplified in any country where neither the competition agency nor the reviewing court may have great expertise in competition matters nor substantial independence from the more political branches of government.

In certain other judicial systems, competition law disputes are handled by specialist tribunals and courts that include both competition law experts and economists. For example, in Chile the government brings its cases before a five-person expert tribunal that includes both expert competition lawyers and economists. ${ }^{348}$ The tribunal also hears certain private competition law claims for damages. Decisions of the tribunal are appealed

${ }^{342} 28$ U.S.C. $\$ 1254$ (certiorari from decisions of circuit courts of appeal); $i d . \$ 1257$ (certiorari from decisions of highest state court); id. $\S 1291$ (appeal to circuit courts from final judgments of district courts).

${ }^{343}$ U.S. CONST. art. VII (declaring that "no fact tried by a jury, shall be otherwise re-examined in any Court of the United States, than according to the rules of the common law").

${ }^{344}$ McWane, Inc. v. FTC, 783 F.3d 814, 824 (11th Cir. 2015).

${ }^{345}$ Microsoft EU, supra note 152, 1 ศा 87-89.

${ }^{346}$ Bernatt, supra note 340 , at 289.

347 See Maciej Bernatt, The Compatibility of Deferential Standard of Judicial Review in the EU Competition Proceedings with Article 6 of the European Convention on Human Rights 1 (Loyola Univ. Chi. Sch. of Law Inst. for Antitrust \& Consumer Studies, Working Paper, 2014), https://papers.ssrn.com/sol3/papers.cfm?abstract_id=2447884 (discussing the counterarguments against the deferential standard of review and surveying literature and suggesting that degree of appellate deference be tied to independence and separation of functions at initial trial or hearing).

${ }^{348}$ Org. FOR ECON. CO-OPERATION \& DEV., ChILE-ACCESSION REPORT ON COMPETITION LAW AND POLICY 30-31, https://www.oecd.org/daf/47950954.pdf (last visited Oct. 3, 2017). 
to the Chilean Supreme Court. ${ }^{349}$ In still other systems, complaints are resolved through administrative proceedings in the national competition authority itself and then appealed to an expert tribunal. ${ }^{350}$

In other legal systems, there is a mix as to the matters that are heard by specialized tribunals and generalist courts. In the UK, the specialized Competition Appeals Tribunal hears all challenges to decisions of the Competition and Markets Authority and also hears certain private competition law damage actions. ${ }^{351}$ The general civil courts hear all other private competition disputes for damages or injunctive relief or where competition issues arise as a defense in related litigation. ${ }^{352}$ The general criminal courts hear the limited number of criminal cases that have been brought in the UK. ${ }^{353}$

As former FTC Chair William Kovacic has noted:

Relatively few of the 130 jurisdictions with competition laws have adopted the U.S. litigation model and its supporting institutions. The EU administrative enforcement regime is by far the world's dominant "operating system." Nearly 80 percent of the world's competition systems rely on an administrative agency that takes decisions and imposes sanctions subject to judicial review. Many countries have adopted his [sic] model to facilitate accession to the European Union. The administrative model also is more attractive to, and compatible with, the civil law regime that most of the world's countries employ. ${ }^{354}$

Regardless of the merits of the U.S. litigation-based model, it remains an outlier.

\section{REMEDIES AND PRIVATE ENFORCEMENT}

The United States has an almost unique system of competition remedies with its heavy reliance on public criminal enforcement and private treble damage litigation. In contrast, most other jurisdictions rely on a civil administrative system of fines, limited criminal prosecutions, and a nascent system of private damage litigation.

\footnotetext{
${ }^{349} \mathrm{Id}$. at 30 .

${ }^{350}$ See Competition Act, R.S.C. 1985, c C-34, s 75 (Can.) (discussing the matters reviewable by the Canadian Competition Tribunal and how such matters are reviewable by the tribunal on application from the Competition Commissioner)

${ }^{351}$ SANDRA MARCo COLINO, COMPETITION LAW OF THE EU AND UK 136-37 (7th ed. 2011).

${ }^{352}$ Id. at $137-39$.

${ }^{353}$ RICHARD WHISH \& DAVID BAILEY, COMPETITION LAW 459-60 (8th ed. 2015) (explaining the Competition and Markets Authority prosecution process).

${ }^{354}$ James Keyte, Interview with Professors Eleanor Fox and William Kovacic, 31 ANTITRUsT 18, 21 (2017).
} 


\section{A. Criminal Enforcement}

The United States is virtually alone with its reliance on criminal enforcement as the primary remedy for hard-core cartel enforcement. The United States helped form a consensus within the OECD to create a recommendation against hard-core cartel. ${ }^{355}$ This is a soft law instrument that does not require criminal penalties, but instead recommends the adoption of:

a) Effective sanctions, of a kind and at a level adequate to deter firms and individuals from participating in such cartels; and

b) Enforcement procedures and institutions with powers adequate to detect and remedy hard core cartels, including powers to obtain documents and information and to impose penalties for noncompliance. ${ }^{356}$

United States antitrust law has had criminal penalties since its inception in 1890. Violations of sections 1 and 2 of the Sherman Act have been felonies since $1974 .{ }^{357}$ Penalties include imprisonment for up to ten years for an individual and fines for corporations up to $\$ 100,000,000$ or the higher of double the gain or loss caused by the unlawful conduct. ${ }^{358}$

Criminal enforcement is reserved for hardcore violations of section 1 of the Sherman Act of agreements between competitors such as price fixing, bid rigging, production levels, territorial allocations, and customer allocations. ${ }^{359}$ These violations are deemed per se unreasonable and almost always prosecuted as criminal violations. ${ }^{360}$ Convictions or guilty pleas are frequent and sentences average in excess of twenty-four months in prison. ${ }^{361}$

355 ORg. For ECON. CO-OPERATION \& Dev., ReCOMmendation of THE OECD COUNCll CONCERning EFFective ACtion against Hard Core Cartels (1998), http://www.oecd.org/daf/competition/2350130.pdf.

${ }^{356} \mathrm{Id}$. art. I.A.1.

${ }^{357}$ Other portions of the antitrust laws also contain criminal sanctions which are not enforced at the present. See, e.g., 15 U.S.C. $\$ 2$ (2012) (monopolization); id. $\S 13$ a (price discrimination); id. $\S 8$ (trusts in restraint of import trade).

${ }^{358} 15$ U.S.C. $\S \S 1-2$.

${ }^{359}$ Bill Baer, Assistant Attorney Gen., Antitrust Div., U.S. Dep't of Justice, Prosecuting Antitrust Crimes, at the Georgetown University Law Center Global Antitrust Enforcement Symposium (Sept. 10, 2014), https://www.justice.gov/atr/file/517741/download.

${ }^{360}$ Id. But see United States v. Apple, 791 F.3d 290, 321-22, 339 (2d Cir. 2015) (holding for the Government in a civil injunction case brought against per se unlawful horizontal conspiracy of book publishers facilitated by Apple, Inc.)

${ }^{361}$ Bill Baer, Assistant Attorney Gen., Antitrust Div., U.S. Dep't of Justice, Reflections on Antitrust Enforcement in the Obama Administration, Remarks as Prepared for Delivery to the New York State Bar Association, New York, N.Y. (Jan. 30, 2014), https://www.justice.gov/atr/file/517761/download. 
While corporations cannot be imprisoned, criminal fines have been imposed as high as $\$ 500,000,000 .^{362}$

Outside the United States, practices vary widely. While most jurisdictions condemn hard-core cartels, they differ as to how to punish them. A 2015 survey found that more than thirty jurisdictions provide for criminal penalties for antitrust violations, but most have done so within the past twenty years. ${ }^{363}$ Few have successfully prosecuted a criminal case and fewer still have actually imprisoned a defendant for such a violation. None do so as a matter of routine as is the case in the United States.

There is a vigorous debate outside the United States whether, when, and how to impose criminal penalties for competition violations. There are reasonable arguments that criminal penalties may not be appropriate for certain jurisdictions for substantive, procedural, institutional, or historical reasons. Not every system provides for competition enforcement against individuals rather than enterprises or undertakings. Not every system has a competition agency with the power to directly prosecute a criminal offense, and most rely on a more complicated referral and cooperation system with the general criminal prosecutor. At the most fundamental level, not every system views the violation of competition norms as the type of fraud and theft by well-dressed thieves as price fixing is characterized in the United States. ${ }^{364}$

For example, the EU has a vibrant competition system but the EU Treaty does not provide for such criminal penalties or only imposes fines on undertakings, rather than individuals. Neither of these bedrock principles is likely to change.

Even a sophisticated competition enforcer like the UK Competition and Markets Authority struggles with the rare criminal proceedings it has brought to date. ${ }^{365}$ Countries like Mexico and Australia have only brought

\footnotetext{
${ }^{362}$ United States v. Hui Hsiung, 758 F.3d 1074, 1080 (9th Cir. 2014), amended and superseded on denial of reh'g en banc, 778 F.3d 738 (9th Cir. 2015). The Swiss pharmaceutical firm Hoffman La-Roche also paid an agreed $\$ 500,000,000$ fine in an international cartel case involving food additives. Press Release, U.S. Dep't of Justice, F. Hoffman-La Roche and BASF Agree to Pay Record Criminal Fines for Participating in International Vitamin Cartel (May 20, 1999).

${ }^{363}$ Gregory C. Shaffer, Nathaniel H. Nesbitt \& Spencer Weber Waller, Criminalizing Cartels: $A$ Global Trend?, in RESEARCH HANDBOOK ON COMPARATIVE COMPETITION LAW 301, 3-4 (John Duns, Arlen Duke \& Brendan Sweeney eds., 2015).

${ }^{364}$ Peter Whelan, The Criminalization of European Cartel Enforcement: Theoretical, Legal, AND Practical Challenges 25-43 (2014); Andreas Stephan, Survey of Public Attitudes to Price Fixing in the UK, Germany, Italy and the USA 19 (Ctr. for Competition Policy, Working Paper No. 15-8, 2015), https://papers.ssrn.com/sol3/papers.cfm?abstract_id=2642181; Peter Whelan, Cartel Criminalization and the Challenge of 'Moral Wrongfulness', 33 OXFORD J. LEGAL STUD. 535, 538 (2013).

365 Cartels 2019 Chapter 11 Criminal Sanctions, Global Legal Insights, https:/www.globallegalinsights.com/practice-areas/cartels-laws-and-regulations/united-kingdom (last visited Nov. 29, 2019).
} 
their first criminal proceedings in the past two years. ${ }^{366}$ New Zealand has only enacted a criminal competition law provision in $2019 .{ }^{367}$

\section{B. Administrative and Civil Fines}

Most other jurisdictions rely instead on civil or administrative fines or penalties to enforce against hard core cartel and related behaviors. The EU competition regulations allow for fines up to ten percent of the worldwide annual turnover of the undertakings found liable. ${ }^{368}$ This is combined with a rebuttable presumption that parent corporations are responsible for the violations of their subsidiaries. The result is fines that often exceed those in the United States and have included fines as high as 4.3 billion euros. ${ }^{369}$ This is the accepted type of remedy for most competition agencies throughout the world. Civil or administrative fines typically are available up to a statutory maximum or a percentage of the turnover of the respondent.

Neither the Antitrust Division nor the FTC can seek fines in civil antitrust matters. ${ }^{370}$ The agencies are limited to civil injunctive relief, which can include under certain limited circumstances restitution or disgorgement of unlawful overcharges. ${ }^{371}$ Such creative injunctive remedies are helpful to consumers, but are the exception and not the rule.

The Antitrust Division has another rarely used remedy. Section 4A of the Clayton Act allows the government to sue for treble damages for any overcharges the federal government paid as the buyer of products or services

${ }^{366}$ See Commonwealth Dir. of Pub. Prosecutions v. Nippon Yusen Kabushiki Kaisha (2017) FCA 876 (Austl.); Solicita COFECE Acción Penal Contra Varias Personas que Pudieron Haberse Coludido en la Venta de Bienes en el Sector Salud, Comisión Federal de Competencia Económica [COFECE Asks for Criminal Prosecution of Several People Who Could Have Colluded in the Sale of Goods in the Health Sector], COFECE (May 2, 2017), https:/www.cofece.mx/solicita-cofece-accion-penal-contra-3personas-que-de-acuerdo-a-sus-investigaciones-se-coludieron-en-la-venta-de-bienes-en-el-sectorsalud/.

${ }^{367}$ Commerce (Criminalisation of Cartels) Amendment Act 2019 (22-1) (N.Z.)

${ }^{368}$ Council Regulation (EC) No. $1 / 2003 \mathrm{ch}$. VI, art. 23(2)(c), On the Implementation of the Rules on Competition Laid Down in Articles 81 and 82 of the Treaty (Text with EEA relevance), 2003 O.J. (L 001), https://eur-lex.europa.eu/legal-content/EN/TXT/HTML/?uri=CELEX:32003R0001\&from=En.

${ }^{369}$ European Commission Press Release IP/18/4581, Antitrust: Commission Fines Google €4.34 Billion for Illegal Practices Regarding Android Mobile Devices to Strengthen Dominance of Google's Search Engine, Brussels (July 18, 2018), http:/europa.eu/rapid/press-release_IP-18-4581_en.htm; see also Case AT.39740, Google Search (Shopping), [2017] 4 C.M.L.R. 12 (imposing a separate two billion euro fine for an earlier decision)

${ }^{370}$ Harry First, The Case for Antitrust Civil Penalties, 76 ANTITRUst L.J. 127, 127-28 (2009). Recently, the chair of the FTC has testified in favor of having such powers. Joe Simons, Chairman, Fed. Trade Comm'n, Oversight of the Federal Trade Commission at the Committee on Energy and Commerce, Subcommittee on Digital Commerce and Consumer Protection, United States House of Representatives, $\begin{array}{lllll}\text { at } & 6-7 & \text { (July } & 18, & 2018) \text {, }\end{array}$ https:/www.ftc.gov/system/files/documents/public_statements/1394526/p180101_ftc_testimony_re_ov ersight_house_07182018.pdf.

${ }^{371}$ FTC v. Abbvie, Inc., 329 F. Supp. 3d 98, 138, 144 (E.D. Pa. 2018). 
as a result of an antitrust violation. ${ }^{372}$ Despite the enormous size of government purchases and the obvious benefits of treble damages to taxpayers, this remedy has been used only sporadically over the years. More recently, the head of the Antitrust Division has stated that he intends to use such suits on a more regular basis. ${ }^{373}$

\section{Private Enforcement}

The other critical fault line between the United States and the rest of the world is the prevalence of private treble damage rights of action in the U.S. Section 4 of the Clayton Act allows all persons injured in their business or property as a result of an antitrust violation to sue for treble damages plus attorneys' fees and costs. ${ }^{374}$ Private persons may also seek injunctive relief, declaratory judgments, and assert antitrust violations as affirmative defenses or counterclaims if sued. ${ }^{375}$

Private antitrust treble damage actions predominate in the United States at a scale unknown in other jurisdictions. Depending on the year, the ratio of private rights of action to federal government cases may be more than twenty to one. ${ }^{376}$ Many are follow-on cases to government criminal cartel cases that are presumptive evidence of a violation in a subsequent private case, leaving the private plaintiff to prove only standing and the amount of harm. ${ }^{377}$

The treble damage remedy in the United States has existed since the passage of the Sherman Act in 1890. However, a vast expansion of private antitrust litigation took place in the mid-twentieth century because of the interaction of various statutory rights and judicial decisions. First, only successful plaintiffs, rather than defendants, are entitled to attorneys' fees and costs. ${ }^{378}$ This distinguishes the antitrust laws from the general U.S. rule that parties pay their own fees and costs, as well as the general rule outside the United States that all losing parties pay the prevailing party's fees and

\footnotetext{
37215 U.S.C. \$ 15(a) (2012).

373 Antitrust SOURCE, EnForcers Roundtable AT THE AmERICAN Bar AsSOCIATION SECTION OF ANTITRUST SPRING MEETING IN WASHINGTON D.C. 23 (2018), https:/www.ftc.gov/system/files/documents/public_statements/1387878/ohlhausen_-

_enforcers_roundtable_3-30-18_.pdf (transcript available through the American Bar Association) (statement of Makan Delrahim, Assistant Attorney General, Antitrust Division); Barry Nigro, Deputy Assistant Attorney Gen., Antitrust Div., Keynote Remarks at the American Bar Association's Antitrust in Healthcare Conference: A Prescription for Competition (May 17, 2018), https://www.justice.gov/opa/speech/deputy-assistant-attorney-general-barry-nigro-delivers-keynoteremarks-american-bar.

${ }^{374} 15$ U.S.C. $\$ 15$ (2012).

37515 U.S.C. $\$ 16(2012)$.

${ }^{376}$ PRIVATE ENFORCEMENT OF ANTITRUST LAWS IN THE UNITED STATES: A HANDBOOK ix (Albert A. Foer \& Randy M. Stutz eds., 2012).

${ }^{377} 15$ U.S.C. $\$ 5(2012)$.

${ }^{378} \mathrm{Id} . \S 15$.
} 
costs. Second, normal tort rules about joint and several liability apply, making each defendant potentially liable for the full amount of any judgment (after trebling). ${ }^{379}$ However, contribution between tortfeasors is not permitted, preventing a defendant from suing its fellow defendants for their share of liability. ${ }^{380}$ Third, antitrust judgments as intentional torts may not be insurable, depending on the precise provisions of state law. ${ }^{381}$ Fourth, normal rules about in pari delicto or unclean hands do not apply in antitrust litigation and do not bar a party who unwillingly participated in a violation from suing to undo an unlawful arrangement or for treble damages where applicable. ${ }^{382}$ Finally, settlements by co-defendants are deductible, but only pre-trebling, ${ }^{383}$ leaving non-settling defendants potentially responsible for the vast amount of a treble damage verdict.

The United States also has general civil procedure rules, unknown in other jurisdictions, which strengthen private antitrust litigation. These include the federal and state constitutional right to jury trial, ${ }^{384}$ the unpredictability and size of potential jury awards, the extensive system of discovery in U.S. civil litigation, ${ }^{385}$ the availability of contingent fees, and the existence of meaningful class actions since the $1960 \mathrm{~s} .^{386}$

At the same time, there has been a judicial and legislative response that has narrowed private antitrust somewhat. The courts have created doctrines of antitrust standing ${ }^{387}$ antitrust injury, ${ }^{388}$ and bars on indirect purchaser actions, ${ }^{389}$ which have limited both certain types of actions and certain categories of plaintiffs. Pleadings requirements have been tightened, first in antitrust conspiracy cases ${ }^{390}$ and then more generally in all civil litigation. ${ }^{391}$ Summary judgment for defendants was made easier for all defendants in a

${ }^{379}$ Tex. Indus. v. Radcliff Materials, Inc., 451 U.S. 630, 646 (1981)

${ }^{380} \mathrm{Id}$. at 646 . But judgment sharing agreements are enforceable and agreements to indemnify have been held to be enforceable as well. See, e.g., In re Brand Name Prescription Drugs Antitrust Litig., 1995 U.S. Dist. LEXIS 4738, at *11 (N.D. Ill. Apr. 11, 1995) (holding that the "defendants" judgment sharing agreement is not unlawful").

${ }^{381}$ Mitchell CheyetTe \& Shawn Parish, California Antitrust \& UnFair Competition LAW $\& 25.02$ (Garrett Lindsey ed., 2017) (explaining that "express coverage for antitrust claims is generally not included in typical business third-party liability insurance policies").

${ }^{382}$ Perma Life Mufflers, Inc. v. Int'I Parts Corp., 392 U.S. 134, 138 (1968).

${ }^{383}$ Burlington Indus. v. Milliken \& Co., 690 F.2d 380, 387 (4th Cir. 1982).

${ }^{384}$ U.S. CONST. art. VII.

${ }^{385}$ FED. R. CIV. P. 26-45.

${ }^{386}$ FED. R. CIV. P. 23

${ }^{387}$ Associated Gen. Contractors of Cal., Inc. v. Cal. State Council of Carpenters, 459 U.S. 519, 535 n.31 (1983).

388 Atl. Richfield Co. v. USA Petroleum Co., 495 U.S. 328, 342 (1990); Matsushita Elec. Indus. Co. v. Zenith Radio Corp., 475 U.S. 574, 586 (1986); Cargill, Inc. v. Monfort of Colo., Inc., 479 U.S. 104 (1986); Brunswick Corp. v. Pueblo Bowl-O-Mat, Inc., 429 U.S. 477, 489 (1977).

${ }^{389}$ Kansas v. UtiliCorp United, Inc., 497 U.S. 199, 225 (1990); Ill. Brick Co. v. Illinois, 431 U.S. 720,724 (1977).

${ }^{390}$ Bell Atl. Corp. v. Twombly, 550 U.S. 544, 552 (2007)

${ }^{391}$ Ashcroft v. Iqbal, 556 U.S. 662, 684 (2009). 
trio of cases including a prominent long running antitrust case involving the electronics industry. ${ }^{392}$

In several circumstances, the Supreme Court has restricted the substance of antitrust rules for fear of overenforcement, almost always in the context of a private treble damages case. ${ }^{393}$ At least one recent appellate case has suggested that certain jurisdictional aspects of foreign commerce antitrust litigation should be narrower in private treble damage actions than in government enforcement actions. ${ }^{394}$

Requirements for certification of class actions have been tightened, ${ }^{395}$ and separate legislation has made it easier for defendants to remove class actions from more plaintiff friendly state courts. ${ }^{396}$ Class actions have been eliminated in many instances through the enforcement of arbitration clauses requiring only individual claims between the parties. ${ }^{397}$

Despite these retrenchments, the uniquely U.S. system for private competition law enforcement has been labeled a "toxic cocktail" by international commentators. ${ }^{398}$ No country would dream of adopting the full panoply of U.S. civil litigation rights and duties in the antitrust area or more generally. Even where private competition law litigation exists, it appears very different from its U.S. equivalent. No major jurisdiction has adopted treble damages. Most employ a strict loser pays principle. None have the

${ }^{392}$ Celotex Corp. v. Catrett, 477 U.S. 317,319 (1986); Anderson v. Liberty Lobby, Inc. 477 U.S. 242 (1986); Matsushita Elec. Indus. Co. v. Zenith Radio Corp., 475 U.S. 574, 577 (1986).

${ }^{393}$ Stephen Calkins, Equilibrating Tendencies in the Antitrust System, With Special Attention to Summary Judgment and Motions to Dismiss, in PRIVATE ANTITRUST Litigation: NEW EVIDENCE, NEW LEARNING ch. 5 (Lawrence J. White ed., 1988); Stephen Calkins, Reflections on Matsushita and "Equilibrating Tendencies": Lessons for Competition Authorities, 82 ANTITRUST L.J. 15, 16 (2018).

${ }^{394}$ Motorola Mobility LLC v. AU Optronics Corp., 775 F.3d 816, 826 (7th Cir. 2015).

${ }^{395}$ See Comcast Corp. v. Behrend, 569 U.S. 27, 38 (2013) (holding the class of subscribers was improperly certified since the subscribers failed to show that common issues of damages predominated in the action as required by F.R.C.P. 23(b)(3)); see also Wal-Mart Stores, Inc. v. Dukes, 564 U.S. 338, 356 (2011) (holding that an employees' class could not be certified because it failed the commonality requirement under F.R.C.P. 23(a)(2)).

396 See Class Action Fairness Act, 28 U.S.C. $\$ 1332$ (d)(2) (LEXIS through Pub. L. No. 116-39) ("The district courts shall have original jurisdiction of any civil action in which the matter in controversy exceeds the sum or value of $\$ 5,000,000$, exclusive of interest and costs, and is a class action in which: (A) any member of a class of plaintiffs is a citizen of a State different from any defendant; (B) any member of a class of plaintiffs is a foreign state or a citizen or subject of a foreign state and any defendant is a citizen of a State; or (C) any member of a class of plaintiffs is a citizen of a State and any defendant is a foreign state or a citizen or subject of a foreign state.").

${ }^{397}$ See Am. Express v. Italian Colors Rest., 570 U.S. 228, 238-39 (2013) (holding that the FAA did not permit courts to invalidate a contractual waiver of class arbitration on the ground that a plaintiff's cost of individuality arbitrating a federal statutory claim exceeded potential recovery); see also AT\&T Mobility LLC v. Concepcion, 563 U.S. 333, 352 (2011) (holding that the Federal Arbitration Act preempted California's Discover Bank Rule); Stolt-Nielsen S.A. v. AnimalFeeds Int'1 Corp., 559 U.S. 662,663 (2010) (holding that an arbitration panel exceeded its powers by concluding that an arbitration clause in the parties' charter was silent with respect to class arbitration).

${ }^{398}$ BARRY RODGER \& ANGUS MACCULLOCH, COMPETITION LAW AND POLICY IN THE EU AND UK 82 (5th ed. 2014). 
broad discovery system of the Federal Rules of Civil Procedure. Some restrict or bar contingent fees. Few have juries for civil litigation of any kind. Most civil law systems rely on a system of judicial sovereignty with the judge conducting the proceeding rather than the adversarial system of the United States.

A wide variety of jurisdictions are developing private damage remedies in competition law. The EU passed a directive requiring its member states to create private rights of action which has recently been implemented by all the member states. ${ }^{399}$ The EU further issued a recommendation on "collective actions" designed to create an EU compatible version of class action without the perceived excesses of the U.S. system. ${ }^{400}$ Private rights of action, either standing alone or following government action, also exist to varying degrees in jurisdictions as diverse as Australia, Canada, Israel, China, Chile, Mexico, and many other jurisdictions. ${ }^{401}$ However, many of these private litigation systems exist on paper only or remain in their infancy.

While the trends for private damage litigation and for class actions between the United States and the rest of the world may be slowly converging, the chance for a meeting somewhere in the middle remains highly unlikely, or at best decades away. For the foreseeable future, the U.S. system will remain defined by heavy reliance on private treble damages competition litigation. The rest of the world will remain heavily dependent on public administrative enforcement with private litigation struggling to supplement the primacy of public administrative competition authorities.

\section{FRONTIER ISSUES}

Big data, algorithmic competition, social media, and related high technology issues represent some of the frontier issues of competition policy. ${ }^{402} \mathrm{~A}$ number of competition agencies have begun to marshal

\footnotetext{
${ }^{399}$ Council Directive 2014/104, 2014 O.J. (L 349) 1 (EC), http://data.europa.eu/eli/dir/2014/104/oj ("This Directive sets out certain rules necessary to ensure that anyone who has suffered harm caused by an infringement of competition law by an undertaking or by an association of undertakings can effectively exercise the right to claim full compensation for that harm from that undertaking or association. It sets out rules fostering undistorted competition in the internal market and removing obstacles to its proper functioning, by ensuring equivalent protection throughout the Union for anyone who has suffered such harm.").

${ }^{400}$ Commission Recommendation 2013/396, 2013 O.J. (L 201) 60, https://eur-lex.europa.eu/legalcontent/EN/TXT/?uri=OJ:JOL_2013_201_R_NS0013 (issuing a recommendation on collective actions).

${ }^{401}$ For a discussion of these varying degrees of private rights of actions across jurisdictions, see Global Antitrust COMPLiance HandBoOK (D. Daniel Sokol et al. eds., 2014), ABA SECTION OF

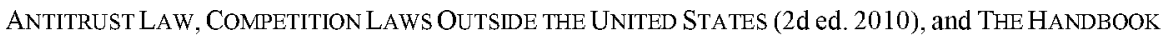
ON PRIVATE ENFORCEMENT OF COMPETITION LAW (Albert A. Foer \& Jonathan W. Cuneo eds., 2010).

${ }^{402}$ ARIEL EzRaChi \& Maurice E. STuCke, Virtual Competition: THE Promise and Perils of THE Algorithm-Driven ECONOMY (2016); Michal GAL, ORG. FOR ECON. COMPETITION \& DEV., Big Data: Bringing Competition Policy to the Digital Era 14 (2016); Maurice Stucke \& Allen GRUNES, Big DATA AND COMPETITION POLICY (2016).
} 
resources to address these issues and formulate comprehensive responses to mergers and potential abuse of dominance by digital platforms with likely market power or dominance in different aspects of social networking, internet retailing, internet search, and behavioral advertising.

Like the prior generation's investigations and litigation against Microsoft for its dominance of operating systems and application software, the United States tentative enforcement and remedies have been substantially exceeded by the EU, its member states, and certain other jurisdictions.

The most innovative enforcement effort to date is the German Bundeskartellampt's preliminary decision against Facebook finding that the company has abused its dominant position in social media by degrading the privacy protections that it promised its users. ${ }^{403}$ This decision was recently reversed by the Higher Regional Court with the German Cartel Office vowing to appeal to the Federal Court of Justice leaving final resolution of the case and the link between privacy and competition unresolved for the near future. Although not part of the German case, the recent revelations of the Facebook data breach involving Cambridge Analytica's acquisition of personal information of at least eighty-seven million users further highlight the importance of the allegations in the German case. ${ }^{404}$

Apple's planned acquisition of the song recognition software company Shazam also raises important links between data privacy and competition in the EU, which are not yet known to be part of any U.S. merger analysis of the transaction. ${ }^{405}$ The EU announced opening a more detailed second phase investigation of the Shazam transaction on the grounds that the transaction may allow Facebook to acquire data on users' relationships with competing digital platforms and allow Facebook to adversely affect the competitive opportunities of those rivals. ${ }^{406}$

${ }^{403}$ See Bunderskartellamt Prohibits Facebook from Combining User Data from Different Sources, BUNDERSKARTELLAMT (July 2019), https://www.bundeskartellamt.de/SharedDocs/Meldung/EN/Pressemitteilungen/2019/07_02_2019_Fac ebook.html ("If consent is not given for data from Facebook-owned services and third party websites, Facebook will have to substantially restrict its collection and combining of data. Facebook is to develop proposals for solutions to this effect.").

${ }^{404}$ See Kevin Granville, Facebook and Cambridge Analytica: What You Need to Know as Fallout Widens, N.Y. TIMES (Mar. 19, 2018), https://www.nytimes.com/2018/03/19/technology/facebookcambridge-analytica-explained.html ("Cambridge Analytica, a political data firm hired by President Trump's 2016 election campaign, gained access to private information on more than 50 million Facebook users. The firm offered tools that could identify the personalities of American voters and influence their behavior.").

${ }^{405}$ See Sissi Cao, Why Tech's 'Big 4' All Faced Antitrust Probes in Europe, But Not in the U.S., N.Y. OBSERVER (Feb. 15, 2018), https://observer.com/2018/02/eu-antitrust-probe-apple-amazonfacebook-google/ ("Apple is currently under an investigation by the European Commission (EC), the EU's law enforcement agency, on its planned acquisition of the U.K.-based song recognition company Shazam.").

${ }^{406}$ See Ivana Kottasová, EU Hits Pause on Apple's Deal to Buy Shazam, CNN (Apr. 23, 2018), 
The EU's abuse of dominance case against Google is probably the most significant case outside the United States. After a lengthy investigation and numerous unsuccessful attempts to reach a settlement, the European Commission reached a decision holding that Google had unlawfully abused its dominance in the internet search market by demoting the search rankings of competing vertical competitors. The Commission fined Google the equivalent of more than 2.7 billion dollars and ordered Google to provide non-discriminatory placement in search results to competitors going forward. ${ }^{407}$ While Google appeals this decision, the Commission issued a new decision imposing a fine of more than five billion dollars in connection with Google's licensing conditions for the Android mobile operating system. ${ }^{408}$

The EU is taking the issue of digital economy quite seriously and undertaking a series of comprehensive studies and measures unlike anything occurring in the United States. It began with a General Directive on Data Privacy which went into effect in May 2018. ${ }^{409}$ The European Commission also has created plans and a framework for a single digital market for the EU as a whole. ${ }^{410}$ Additionally, the Commission has begun an investigation of Amazon's dual role as merchant and platform operator. ${ }^{411}$

The Competition Directorate of the Commission has followed up on these developments and created a Digital Advisory Panel to focus on the

https://money.cnn.com/2018/04/23/technology/apple-shazam-eu-antitrust-investigation/index.html, ("The European Commission has launched an in-depth investigation into Apple's acquisition of music recognition app Shazam, delaying one of the tech company's biggest deals by at least four months.").

${ }^{407}$ See European Commission Press Release IP/18/4581, Antitrust: Commission Fines Google €4.34 Billion for Illegal Practices Regarding Android Mobile Devices to Strengthen Dominance of Google's Search Engine (July 18, 2018), http:/europa.eu/rapid/press-release_IP-18-4581_en.htm ("The European Commission has fined Google $€ 4.34$ billion for breaching EU antitrust rules. Since 2011, Google has imposed illegal restrictions on Android device manufacturers and mobile network operators to cement its dominant position in general internet search.").

${ }^{408}$ See Foo Yun Chee, EU Antitrust Chief Says Investigation of Google's Android, AdSense is Advancing, REUTERS (Apr. 18, 2018), https://www.reuters.com/article/us-eu-google-antitrust/euantitrust-chief-says-investigation-of-googles-android-adsense-is-advancing-idUSKBN1HP2YL (“A 2016 document seen by Reuters said the EU competition enforcer planned to levy a large fine against the company and would order it to stop giving revenue-sharing payments to smartphone makers to pre-install only Google Search.").

${ }^{409}$ See Commission Regulation 2016/679, 2016 O.J. (L 119/1) (taking effect May 25, 2018).

${ }^{410}$ Commission Staff Working Document on the Free Flow of Data and Emerging Issues of the European Data Economy, EuR. COMM'N (Oct. 1, 2017), https://ec.europa.eu/digital-singlemarket/en/news/staff-working-document-free-flow-data-and-emerging-issues-european-data-economy.

411 See European Commission Press Release IP/19/4291, Antitrust: Commission Opens Investigation Into Possible Anti-competitive Conduct of Amazon, (July 16, 2019), https://ec.europa.eu/commission/presscorner/detail/en/ip_19_4291 ("The European Commission has opened a formal antitrust investigation to assess whether Amazon's use of sensitive data from independent retailers who sell on its marketplace is in breach of EU competition rules."). 
challenges of digitization for competition policy. ${ }^{412}$ The UK Competition and Markets Authority announced that it will have a specialist data unit following the recommendation of the blue ribbon expert panel known as the Furman Report. ${ }^{43}$ The French Autorite de la concurrence and the German Bundeskartellamt also have launched a joint project on algorithms and competition law. ${ }^{414}$

Other jurisdictions and organizations are starting to think systematically about the unique challenges to competition law posed by digitization, the growth of big data, and other aspects of the internet. The OECD has conducted several workshops on these issues. ${ }^{415}$ The French competition

${ }^{412}$ EU: Vestager creates Digital Markets Advisory panel, COMPETITION POL'Y INT'L (Apr. 3, 2018), https://www.competitionpolicyinternational.com/eu-vestager-creates-digital-markets-advisorypanel/.

${ }^{413}$ See Unlocking Digital Competition, DigiTal COMPETITION EXPERT PANEL (Mar. 2019), https://assets.publishing.service.gov.uk/government/uploads/system/uploads/attachment_data/file/7855 47/unlocking_digital_competition_furman_review_web.pdf ("This is why the Panel is recommending the establishment of a digital markets unit, given a remit to use tools and frameworks that will support greater competition and consumer choice in digital markets, and backed by new powers in legislation to ensure they are effective."); see also Tom Madge-Wyld, New CMA Data Unit Expected This Summer,
GLOBAL
COMPETITION
REV.
(Feb.
23 ,
2018), https:/globalcompetitionreview.com/article/1 164238/new-cma-data-unit-expected-this-summer ("The new data unit at the UK's Competition and Markets Authority should be up and running by the summer, the agency's chief executive has said, which will beef up enforcement on digital tools and algorithms.").

${ }^{414}$ The French Autorité de la concurrence and the German Bundeskartellampt Launch a Joint Project on Algorithms and Their Implications on Competition, BUNDESKARTELLAMT (June 19, 2018), https://www.bundeskartellamt.de/SharedDocs/Meldung/EN/Pressemitteilungen/2018/19_06_2018_Alg orithmen.html

${ }^{415}$ See ORg. FOR ECON. CO-OPERATION \& DEV., OECD REVIEws OF Digital TRANSFORMATION: GOING DIGITAL IN SWEDEN 3 (2018), https:/read.oecd-ilibrary.org/science-and-technology/oecdreviews-of-digital-transformation-going-digital-in-sweden_9789264302259-en\#page1 (examining the recent developments in infrastructures for the digital economy, telecom markets, and related regulations and policies in Sweden); see also ORG. FOR ECON. CO-OPERATION \& DEV., SUMMARY OF DISCUSSION $\begin{array}{lllllll}\text { OF THE HEARING ON BIG DATA } & 2 & \text { (2016), }\end{array}$ https://one.oecd.org/document/DAF/COMP/M(2016)2/ANN2/FINAL/en/pdf ("The Hearing on Big Data aimed at identifying some of the competition challenges from the increasing use of consumer data for business purposes, and to discuss possible reactions by competition authorities and other agencies. The chairman opened the roundtable by introducing the panellists and organised the session in three parts: a first part on the impact of Big Data on innovation and market power; a second part about the implications of big data for competition law enforcement; and a short third part about whether other regulations should be applied or even substitute the role of competition policy."); Workshop on Regulation and Competition in Light of Digitalization, OECD (Jan. 31, 2018), http://www.oecd.org/competition/workshop-on-competition-regulation-and-digitalisation.htm ("The OECD organised a one-day workshop for competition official on 31 January 2018 in Paris to provide insights into how common restrictions, arising in the context of digitalisation, are identified and analysed by competition authorities and other agencies."). 
agency has completed a market study of online advertising. ${ }^{416}$ The EU, ${ }^{417}$ the Canadian Competition Bureau, ${ }^{418}$ South Africa, ${ }^{419}$ the German Bundeskartellamt, on its own, and in conjunction with the French Competition Authority, ${ }^{420}$ and the Japanese Fair Trade Commission ${ }^{421}$ all have issued statements or reports outlining their approaches to "big data" as competition agencies. The UK has the Furman Report. ${ }^{422}$ The French and German competition agencies have announced a joint project on how to classify and analyze algorithms. ${ }^{423}$ The Australian competition agency has announced a Digital Platform Inquiry. ${ }^{424}$ Most recent, the UK announced the

\footnotetext{
${ }^{416}$ See Charlotte Breuvart, Eric Barbier de la Serre \& Laurent De Muyter, French Competition Authority Concludes Online Advertising Sector Inquiry and Announces Possible Further Actions, $\begin{array}{llllll}\text { KLUWER COMPETITION } & \text { L. BLOG } & \text { (Mar. } & 16,\end{array}$ http://competitionlawblog.kluwercompetitionlaw.com/2018/03/16/french-competition-authorityconcludes-online-advertising-sector-inquiry-announces-possible-actions/ ("In May 2016, the FCA and the German Bundeskartellamt published a joint report on Big Data and its implications for competition law. While the Bundeskartellamt followed up the report with investigations in the social media sector, the FCA initiated a sector-specific inquiry focused on display online advertising, which complemented its earlier 2010 report on search advertising.").

417 Commission Decision No. 2018/1927, 2018 O.J. (L 313) 39 (EU), https://eurlex.europa.eu/legal-content/EN/TXT/PDF/?uri=CELEX:32018D1927\&qid=1568181960167\&from=E N.

${ }^{418}$ Big Data and Innovation: Key Themes for Competition Police in Canada, CoMPETITION BuREAU CAN. (Feb. 19, 2018), https://www.competitionbureau.gc.ca/eic/site/cb-bc.nsf/vwapj/CBReport-BigData-Eng.pdf/\$file/CB-Report-BigData-Eng.pdf. The Bank of Canada has also weighed in on this issue. Blake Cassels \& Graydon LLP, Canadian Competition Policy Focuses in on "Big Data", LEXOLOGY (Feb. 20, 2018), https:/www.lexology.com/library/detail.aspx?g=140bcc47-fd72-44f2ba18-e6ac7647785f.

419 COMPETItion COMM'N S. AFR., DATA SERVices MARkET InQuRY: Summary OF PROVISIONAL FINDINGS AND RECOMMENDATIONS (2019), http://www.compcom.co.za/wpcontent/uploads/2019/04/Data-Services-Inquiry-Summary.pdf.

${ }^{420}$ New Series of Bundeskartellamt Papers on "Competition and Consumer Protection in the Digital Economy", $\quad$ Bundeskartellamt (Oct. 6, 2017), https:/www.bundeskartellamt.de/SharedDocs/Meldung/EN/Pressemitteilungen/2017/06_10_2017_Sch riftenreihe\%20Digitales.html; The French Autorite de la Concurrence and the German Bundeskartellamt Publish Joint Paper on Data and its Implications for Competition Law, BUNDESKARTELLAMT (May 10, 2016),

https:/www.bundeskartellamt.de/SharedDocs/Meldung/EN/Pressemitteilungen/2016/10_05_2016_Big $\% 20$ Data\%20Papier.html.

${ }^{421}$ Press Release, Japan Fair Trade Comm'n, Report of Study Group on Data and Competition Policy (June 6, 2017), https://www.jftc.go.jp/en/pressreleases/yearly-2017/June/170606.html. Furman).

${ }^{422}$ Unlocking Digital Competition, supra note 413 (introductory letter from panel chair Jason

${ }^{423}$ The French Autorite de la Concurrence and the German Bundeskartellamt Launch a Joint Project on Algorithms and their Implications on Competition, BUNDESKARTELLAMT (June 19, 2018), https://www.bundeskartellamt.de/SharedDocs/Meldung/EN/Pressemitteilungen/2018/19_06_2018_Alg orithmen.html

${ }^{424}$ Rod Sims, Chairman, Australian Competition \& Consumer Comm'n, Speech at the International Institute of Communications - Telecommunications and Media Forum: Regulating for Competition: Stepping up for Platforms \& Stepping Back from Media? (July 3, 2018), transcript available at https://www.accc.gov.au/speech/regulating-for-competition-stepping-up-for-platforms-stepping-backfrom-media.
} 
creation of an independent task force to examine competition in digital markets. ${ }^{425}$

In contrast, the United States has shown caution in enforcement and lack of interest in the big data field as a separate policy matter. Most mergers in data driven markets have been approved without conditions. ${ }^{426}$ The FTC chose not to bring an expansive case against Google for monopolization and unfair methods of competition despite a staff recommendation to do so. ${ }^{427}$ Instead, the FTC settled limited charges through an unusual voluntary letter agreement rather than a binding consent decree. ${ }^{428}$ There are no publicly available plans for a revived or revised investigation by the FTC, and currently it is a coalition of fifty States and territories which are investigating Google. ${ }^{429}$

As of the fall of 2019 , no significant U.S. federal cases are underway involving the tech giants facing competition scrutiny in multiple jurisdictions abroad. The head of the Antitrust Division signaled in 2018 that his agency is unlikely to undertake such a case, stating that consumer choice rather than antitrust enforcement should guide the evolution of digital platforms. $^{430}$

${ }^{425}$ HM Treasury \& The Rt. Hon. Philip Hammond MP, Work Kicks-off to Examine Digital Competition in UK, GOV.UK (Sept. 19, 2018), https://www.gov.uk/government/news/work-kicks-offto-examine-digital-competition-in-uk.

426 See, e.g., Press Release, Fed. Trade Comm'n, Federal Trade Commission Closes Google/DoubleClick Investigation (Dec. 20, 2007), https:/www.ftc.gov/news-events/pressreleases/2007/12/federal-trade-commission-closes-googledoubleclick-investigation (explaining that no conditions were imposed on the Google/DoubleClick merger because there was no chance of competitive harm). See Stucke \& Grunes, supra note 402, at 69-104 (surveying unchallenged recent merger investigation involving big data).

${ }^{427}$ Press Release, Fed. Trade Comm'n, Statement of the Federal Trade Commission Regarding Google's Search Practices In the Matter of Google Inc. FTC File Number 111-0163 (Jan. 3, 2013), https://www.ftc.gov/sites/default/files/documents/public_statements/statement-commission-regardinggoogles-search-practices/130103brillgooglesearchstmt.pdf. See also Jamie Condliffe, Leaked 2012 Report Says FTC Staff Wished to Sue Google Over Result Skews, GizModo (Mar. 20, 2015), https://gizmodo.com/new-leaked-report-describes-how-ftc-staff-wanted-to-sue-1692564840 (stating that the FTC initially wanted to sue Google for "skewing" searches).

${ }^{428}$ Press Release, Fed. Trade Comm'n, Google Agrees to Change Its Business Practices to Resolve FTC Competition Concerns in the Markets for Devices Like Smart Phones, Games and Tablets, and in Online Search (Jan. 3, 2013), https://www.ftc.gov/news-events/press-releases/2013/01/google-agreeschange-its-business-practices-resolve-ftc. An unrelated portion of the case was settled through a binding consent decree involving the licensing of standard essential patents relating to cell phone technology that Google acquired through a prior acquisition from Motorola. Id.

429 Associated Press, Google Faces Antitrust Investigation by 50 U.S. States and Territories, GUARDIAN (Sept. 9, 2019), https://www.theguardian.com/technology/2019/sep/09/google-antitrustinvestigation-monopoly.

${ }^{430}$ See David McLaughlin, Trump Antitrust Chief Says no Sign of Competitive Harm from Tech, BLOOMBERG (Sept. 28, 2018), https://www.bloomberg.com/news/articles/2018-09-28/trump-antitrustchief-says-no-sign-of-competitive-harm-from-tech ("Major online platforms have significant market power, but the question for antitrust enforcers is whether or not they're taking steps to stifle innovations that challenge that dominance, . . . ."); Makan Delrahim, Assistant Attorney Gen., Dep't of Justice, Keynote Address at the University of Chicago's Antitrust and Competition Conference (Apr. 19, 2018), 
In the past year, the U.S. rhetoric has somewhat changed, ${ }^{431}$ but not the enforcement record. The FTC has created a high tech taskforce to explore future options. ${ }^{432}$ In addition, the U.S. enforcement agencies have agreed that the Antitrust Division will conduct any resulting investigations of Google and Apple, while the FTC will conduct any investigations of Amazon and Facebook. ${ }^{433}$ Any enforcement actions would be in the medium to long term and would be subject to the narrower U.S. vision of the abuse of market power versus the more expansive EU toolkit in this area.

A simple recent illustration of this digital divide in antitrust enforcement took place in separate interviews by the head of the Antitrust Division and the Competition Directorate of the EU. Makan Delrahim gave an interview to the Financial Times where he stated that the tech giants were a source of "great efficiencies." ${ }^{.434}$ In contrast, Margethe Vestager of the EU stated that if there's no regulation, "you have just the laws of the jungle and not the laws of democracy." $" 435$

\section{NORMATIVE IMPLICATIONS}

The isolation of U.S. antitrust across many key substantive, procedural, and institutional aspects affects our interactions with the rest of the competition law community. This Section explores how we got here and its normative implications.

\section{A. History and Culture}

Much of the growing and persistent isolation of U.S. antitrust is a function of history and path dependence. Antitrust in the United States began at the state level in the 1880 s with the federal government following a decade

\footnotetext{
https://www justice.gov/opa/speech/assistant-attorney-general-makan-delrahim-delivers-keynoteaddress-university-chicagos (explaining that the first "component" of antitrust is consumer welfare).

${ }^{431}$ Justice News, Assistant Attorney General Makan Delrahim Delivers Remarks at ABA's 2019 Antitrust Fall Forum, Washington, DC, Monday, November 18, 2019 , https://www.justice.gov/opa/speech/assistant-attorney-general-makan-delrahim-delivers-remarks-abas2019-antitrust-fall-forum.

${ }^{432}$ Press Release, Fed. Trade Comm'n, FTC's Bureau of Competition Launches Task Force to Monitor Technology Markets (Feb. 26, 2019), https://www.ftc.gov/news-events/pressreleases/2019/02/ftcs-bureau-competition-launches-task-force-monitor-technology.

${ }^{433}$ David McLaughlin \& Naomi Nix, Google's Enemies Sharpen Complaints as DOJ Opens Antiturt Probe, BLOOMBERG POL. (June 4, 2019), https://www.bloomberg.com/news/articles/2019-0604/google-s-enemies-sharpen-complaints-as-doj-opens-antitrust-probe.

${ }^{434}$ PYMNTS, Antitrust Chief: Tech Dealmaking Spawns 'Great Efficiencies', PYMNTS.COM (July 12, 2018), https://www.pymnts.com/antitrust/2018/makan-delrahim-antitrust-big-tech-businessregulation/.

${ }^{435}$ David Brancaccio \& Janet Nguyen, Europe's Top Antitrust Official: If There's no Regulation, "You Have Just the Laws of the Jungle and not the Laws of Democracy", MARKETPLACE (Apr. 12, 2018), https://www.marketplace.org/2018/04/12/business/facebook-fallout/woman-going-after-worldsbiggest-tech-companies.
} 
later with the Sherman Act. ${ }^{436}$ The open-ended, broadly worded, almost constitutional, language of the Sherman Act was a product of its times and the U.S. common law system. While the United States has been influential to varying degrees in the adoption of other jurisdictions' competition systems, the other systems all were adopted or modified into their modern forms much later and in very different legal and societal climates. ${ }^{437}$ There is no reason to think that copying the United States was the principal reason for their outcome or evolution. ${ }^{438}$

There is every reason to believe that most competition systems around the world have emulated the EU rather than the United States. Competition law is part of the "acquis communautaire" that all member states are required to incorporate into their own national law. ${ }^{439}$ All current member states have national competition law that closely tracks the competition laws of the EU and may not conflict with its core provisions. ${ }^{440}$ Special provisions also allow member states to have broader laws regarding abuse of a dominant position. ${ }^{441}$

Many of these competition provisions were explicitly adopted by countries in order to facilitate eventual membership in the EU. Other countries adopted EU style provisions out of necessity or choice in connection with their membership in the EU or the European Free Trade Agreement, or to secure preferential trade agreements with the EU ${ }^{442}$ Still others have colonial or cultural ties with EU countries that made EU style competition law a more natural fit.

Even Japan and Germany, where the United States exerted more direct influence following the end of World War II, quickly modified their original

\footnotetext{
${ }^{436} 15$ U.S.C. $\$ \S 1-7$ (2012).

${ }^{437}$ See Amedeo Arena, The Relationship Between Antitrust and Regulation in the US and the EU: Can Legal Tradition Account for the Difference?, 3 CAMBRIDGE J. INT'L \& COMP. L. 330, 354-56 (2014) (comparing and contrasting antitrust in the United States and the EU).

${ }^{438}$ See DAVID GERBER, LAW AND COMPETITION IN TWENTIETH-CENTURY EuRope: ProteCTING PROMETHEUS 115-21 (2001) (crediting, partially, the evolution of competition antitrust law to postWorld War I discussions).

${ }^{439}$ Commission Communication to the European Parliament and the Council on Codification of the Acquis Communautaire, COM (2001) 645 final (Nov. 21, 2001).

${ }^{440}$ See Council Regulation No. 1/2003 of 16 December 2002 on the Implementation of the Rules on Competition Laid Down in Articles 81 and 82 of the Treaty, pmbl. (22), 2003 O.J. (L 001) 1, 5 (EC) https:/eur-lex.europa.eu/legal-

content/EN/TXT/PDF/?uri=CELEX:32003R0001\&qid=1568179654008\& from=EN ("In order to ensure compliance with the principles of legal certainty and the uniform application of the Community competition rules in a system of parallel powers, conflicting decisions must be avoided.").

${ }^{441}$ See id. art. 3(2) ("Member States shall not under this Regulation be precluded from adopting and applying on their territory stricter national laws which prohibit or sanction unilateral conduct engaged in by undertakings.").

${ }^{442}$ A.E. Rodriguez \& Malcolm B. Coate, Limits to Antitrust Policy for Reforming Economies, 18 Hous. J. INT'L L. 311, 327-29 (1996) (discussing antitrust law reforms in Albania, Bulgaria, the Czech Republic, Estonia, Hungary, Latvia, Lithuania, Poland, Romania, Russia, Slovakia, and Slovenia).
} 
competition laws to fit their indigenous needs and diverged from whatever U.S. roots from which they grew. ${ }^{443}$ If there is a competition for the hearts and minds of the world's one hundred thirty plus competition systems, the EU has long since acquired a dominant position.

Two recent examples illustrate this type of divergence where very different jurisdictions either adopted or modified their competition laws ultimately adopting language and approaches developed for their national needs more in line with EU competition principles. More than fifteen years ago, China began a systematic study of world competition systems to develop its first competition law as part of the promotion of its socialist market economy. Scholars note that the PRC relied on key EU, and less so U.S., concepts and sources in selecting the rules, procedures, and institutions that best suited their needs. ${ }^{444}$

Chile also has modified its competition laws in recent years. The new statutory language echoes that of Articles 101 and 102, even though key concepts remain undefined by guidelines or precedent. For example, Article $3(\mathrm{a})$, amended in 2016, prohibits agreements or concerted practices that involve competitors and consist of fixing sale or purchase prices, limit production, allow them to assign market zones or quotas, or affect the result of bidding processes, as well as agreements or concerted practices that confer them market power, consist in determining marketing conditions, or that exclude competitors. ${ }^{455}$ Article 3(b) incorporates the familiar EU notion of abuse of dominance. ${ }^{446}$

The dominance of EU style competition policy seems unlikely to abate. Similarly, it is difficult to see which jurisdiction has bucked, or is likely to buck, that trend and adopt the narrow substantive, procedural, institutional, and remedial U.S. approach as its playbook for competition policy.

\section{B. Ideology}

Some of the enduring and increasing isolation of United States antitrust in the world community also is a function of ideology. As Professor Eleanor Fox has noted:

In the matter of single-firm conduct, the U.S., especially as recited in the Trinko case, is laissez faire; it makes assumptions that the EU does not make. The default presumptions are very powerful. For example: if you are

${ }^{443}$ Gerber, Prometheus, supra note 438, at 115-21; Etsuko KameOKA, COMPETITION LAW AND POLICY IN JAPAN AND THE EU 10-20 (2014); David J. Gerber, Constitutionalizing the Economy: German Neo-Liberalism, Competition Law and the "New" Europe, 42 AM. J. COMP. L. 25, 25 (1994).

${ }^{444}$ H. STEPHEN HARRIS, JR. ET AL., ANTI-MONOPOLY LAW AND PRACTICE IN CHINA 2-4 (2011); XiaOYe WANG, THE EVOlution OF CHINA's ANTI-MONOPOLY LAW 261 (2014)

${ }^{445}$ Law No. 211 art. 3(a), Augusto 30, 2016, GACETA JuRídICA [G.J.] (Chile).

${ }^{446}$ Id. art. 3(b). 
acting as a single firm (not in conspiracy with competitors), you're probably going to do what's best for the market if government leaves you alone. That is because (the assumptions go) markets work well and will punish you if you try to harm competition. ${ }^{447}$

Taking the U.S. agencies and courts at their word, the sole or principal objective of U.S. antitrust is the promotion of consumer welfare defined in a narrow price theory fashion. ${ }^{448}$ While many commentators dispute whether this is true historically or desirable normatively, this is the gospel that the U.S. agencies preach in their dealings with other jurisdictions.

The United States has pursued a policy of promoting its view of best practices to other jurisdictions in a variety of fora. First, the United States worked to oppose the inclusion of competition rules in the WTO negotiations because of concern that binding rules would be adopted that differed from U.S. practice and interests. ${ }^{449}$ Instead, the United States promoted the creation of the International Competition Network (ICN), a virtual organization that would be voluntary, consensus driven, and focused on development of best practices. ${ }^{450}$ The United States has worked through both government agency personnel and non-governmental advisers to promote its view of best practices to varying degrees of success since the creation of the ICN over both Republican and Democratic administrations.

From this perspective, the ICN report card is mixed. As noted throughout this Paper, the ICN often has documented the diversity of competition law practice rather than promote the substantive convergence of competition hoped for by U.S. interests. The ICN has been very valuable as a teaching tool and as a forum for the sharing of information and practice among diverse jurisdictions, but it has not resulted in most jurisdictions becoming a mirror for the United States. More often than not, other jurisdictions enforce their own competition laws knowledgeably and effectively but do not do so by adopting the existing U.S. approach.

A similar pattern exists in the other U.S. interactions in international organizations, regional trade arrangements, and bilateral relationships in the competition sphere. This is the case at the Organisation for Economic Cooperation and Development (OECD), where most of the members follow the $\mathrm{EU}$, rather than the U.S., model for competition matters. ${ }^{451}$ It is true at the

\footnotetext{
${ }^{447}$ See Keyte, supra note 354, at 24-25.

${ }^{448}$ Makan Delrahim, Assistant Attorney Gen., Dep't of Justice, Anticompetitive Effects of Regulation (May 31, 2018).

${ }^{449}$ Merit E. Janow \& James F. Rill, The Origins of the ICN, in THE INTERNATIONAL COMPETITION NETWORK AT TEN: ORIGINS, ACCOMPLISHMENTS AND ASPIRATIONS 26 (Paul Lugard ed., 2011).

${ }^{450} \mathrm{Id}$. at $28-34$.

${ }^{451}$ Our Global Reach, OECD, http://www.oecd.org/about/membersandpartners/list-oecd-membercountries.htm (last visited Sept. 12, 2019).
} 
United Nations Conference on Trade and Development (UNCTAD), which is dedicated to the interests of smaller and developing jurisdictions. ${ }^{452}$ It is similarly the case at The World Bank which views competition law as part of a developmental agenda. ${ }^{453}$

A cursory review of the work product of important organizations such as the ICN and the OECD shows the diversity of opinion on a plethora of key competition issues. Two surveys help illustrate the extent of the divergence. The first survey relates to the goals of competition law itself. That survey notes that a majority of the respondents identified the promotion of consumer welfare as only one of several goals for competition law. ${ }^{454}$

A second ICN survey on unilateral conduct provisions similarly shows the wide gulf between U.S. practice and the rest of the world. The survey begins with a list of ten different goals for single firm conduct provisions which include:

1) Ensuring an effective competitive process;

2) Promoting consumer welfare;

3) Maximizing efficiency;

4) Ensuring economic freedom;

5) Ensuring a level playing field for small and medium size enterprises;

6) Promoting fairness and equality;

7) Promoting consumer choice;

8) Achieving market integration;

9) Facilitating privatization and market liberalization; and

10) Promoting competitiveness in international markets. ${ }^{45}$

Not all of the isolation of U.S. antitrust is related to the rejection of economic analysis, or the preferencing of other normative values such as the

\footnotetext{
452 See Mandate and Key Functions, U.N. CONF. ON TRADE \& Dev., http://unctad.org/en/Pages/DITC/CompetitionLaw/ccpb-Mandate.aspx (last visited Aug. 3, 2018) (listing the purpose of the UNCTAD).

453 Markets and Competition Policy, WORLD BANK GROUP, http://www.worldbank.org/en/topic/competition-policy (last visited Aug. 6, 2018). See also Markus Kitzmuller \& Martha Martinez Licetti, Competition Policy: Encouraging Thriving Markets for Development, VIEWPOINT, Sept. 2012, at 1-2 (arguing that various studies show that competition law is directly connected to productivity growth).

${ }^{454}$ INT'L COMPETITION NETWORK, COMPETITION ENFORCEMENT AND CONSUMER WELFARE: $\begin{array}{llll}\text { SETTING } & \text { THE } & \text { AGENDA } & 11\end{array}$ http://www.internationalcompetitionnetwork.org/uploads/library/doc857.pdf.

${ }^{455}$ INT'L COMPETITION NETWORK, UCWG, REPORT ON THE OBJECTIVES OF UNILATERAL Conduct Laws, Assessments of Dominance/Substantial Market Power, AND STATE-Created MONOPOLIES 5-20 (2007), http://www.internationalcompetitionnetwork.org/uploads/library/doc353.pdf.
} 
single market imperative, ordoliberalism, promotion of democratic values, or notions of industrial policy embedded within competition law systems. Even within the economic community, U.S. economists tend to be more favorable to economic ideas based on free trade and market competition than their British, French, or German peers. ${ }^{456}$ The same appears to true for U.S. society as a whole in comparison to its EU counterparts. ${ }^{457}$

Most of the discourse in these fora is civil and sophisticated. Countries have learned much from each other as to best practices and achieved limited harmonization in certain areas. ${ }^{458}$ More often than not, the United States remains a seller, rather than a buyer, and frequently comes home empty handed.

Other times, U.S. frustration with other jurisdictions' conduct bubbles over both in public and private. These incidents have arisen in both Republican and Democratic administrations and generally fall in one of three camps. The foreign enforcer (often the EU) often is criticized for not applying sound economics; protecting competitors, and not competition; taking action when the U.S. agencies have refrained or limited their actions; or applying competition law in a discriminatory manner against a U.S. respondent. ${ }^{459}$

The main source of antitrust enforcement strife between the United States and the European Union during the Clinton Administration came with the difference in opinion regarding the Boeing/McDonnell-Douglas merger. This merger was cleared in the United States largely on the grounds that the merger would not likely cause a substantial lessening of competition because of the weakening over time of McDonnell-Douglas's market position. ${ }^{460}$ The

\footnotetext{
${ }^{456}$ MARION FOURCADE, ECONOMISTS AND SOCIETIES: DISCIPLINE AND PROFESSION IN THE UNITED STATES, BRITAIN, AND FRANCE, 1890s TO 1990s, at 5 (2009).

${ }^{457}$ Sokol, supra note 5, at 977.

${ }^{458}$ See Spencer Weber Waller, The Internationalization of Antitrust Enforcement, 77 B.U. L. REV. 343, 347-48 (1997) (discussing similarities in countries' antitrust laws).

459 See William H. Page \& John E. LopatKa, The Microsoft Case: antitrust, High TECHNOLOGY, AND CONSUMER WELFARE 246-47 (2007) (discussing the need for global antitrust enforcement reform and criticism of EU antitrust law). It should also be noted that foreign jurisdictions similarly protest and criticize the United States when their undertakings are the subject of U.S. antitrust enforcement actions. See 1 SPENCER WeBER WALlER \& ANDRE FIEBIG, ANTITRUST \& AMERICAN BUSINESS ABROAD $\S \S 5.2,5.3$ (4th ed. 2018) (discussing differences in antitrust law between the United States and other countries).

${ }^{460}$ Statement of Chairman Robert Pitofsky and Commissioners Janet D. Steiger, Roscoe B. Starek III and Christine A. Varney in the Matter of The Boeing Company/McDonnell Douglas Corporation, FED. TRADE COMMISSION (July 1, 1997), https://www.ftc.gov/public-statements/1997/07/statementchairman-robert-pitofsky-commissioners-janet-d-steiger-roscoe-b. See also Statement of Commissioner Mary L. Azcuenaga in The Boeing Company, FED. TRAde Commission (July 1, 1997), https://www.ftc.gov/public-statements/1997/07/statement-commissioner-mary-1-azcuenaga-boeingcompany (discussing the Boeing and McDonnell Douglas merger).
} 
transatlantic controversy began when the EU threatened to block the merger entirely and ultimately imposed substantial conditions on its approval. ${ }^{461}$

President Clinton expressed his concerns about the European Commission's reasons for opposing the merger and noted that it would be "unfortunate" if the United States entered into a trade standoff with the EC. ${ }^{462}$ Clinton also speculated about going to the World Trade Organization or sanctioning European countries if the European Commission continued opposing the merger. ${ }^{463}$

President Clinton also noted that the EU appeared to be making a political decision to protect Airbus. Clinton stated, "the Europeans have more people living on their continent than we do in the United States, and I don't believe Airbus has an effective competitor in Europe." ${ }^{464}$ Top administration officials, including United States Trade Representative Charlene Barshefsky and Commerce Secretary William Daley, hinted at U.S. retaliation if the EU continued to oppose the merger. ${ }^{465}$

The first major antitrust enforcement disagreement between the United States and the EU occurred during the Bush Administration over the proposed merger between GE and Honeywell. This was the first time that foreign regulators fully blocked a proposed merger between two U.S. companies. President George W. Bush noted that he wanted U.S. companies to be treated fairly in Europe and that he was concerned that the European Commission was making their decisions in an effort to appease Airbus. ${ }^{466}$ President Bush also questioned the European Commission's demand that GE sell off several of its aircraft engineering units after the Canadian and U.S. regulators had already approved the deal. ${ }^{467}$

\footnotetext{
${ }^{461}$ Commission Decision 97/816, of 30 July 1997 Declaring a Concentration Compatible with the Common Market and the Functioning of the EEA Agreement, 1997 O.J. (L 336) 16, 34-37, 39-40 (EC), https://eur-lex.europa.eu/legal-content/EN/TXT/PDF/?uri=CELEX:31997D0816\&from=EN (decision listing the contingencies that Boeing must meet for the $\mathrm{EU}$ to approve of the merger).

${ }^{462}$ Alison Mitchell, Clinton Warns Europeans of Trade Complaint on Boeing Deal, N.Y. TIMES (July 18, 1997), https://www.nytimes.com/1997/07/18/business/clinton-warns-europeans-of-tradecomplaint-on-boeing-deal.html.

${ }^{463} \mathrm{Id}$.

${ }^{464} \mathrm{Id}$.

${ }^{465}$ Brian Coleman, Clinton Hints at U.S. Retaliation if EU Blocks Boeing Merger, WALL ST. J. (July 18, 1997, 2:20 AM), https://www.wsj.com/articles/SB86915484794977500?ns=prod/accountswsj.

466 See Benjamin Wootliff, Bush Under Fire Over GE, TELEgrapH (June 19, 2001), https://www.telegraph.co.uk/finance/2722600/Bush-under-fire-over-GE.html (reporting that "President Bush remarked that he was "concerned that the EU appeared to be blocking the sale of [Honeywell's] avionics and engineering group" to GE, and that the European competition commission "dismissed concerns that it had been influenced by Airbus").

${ }^{467} \mathrm{Id}$.
} 
After the EU announced its decision, Treasury Secretary Paul H. O'Neill fervently criticized the outcome as "off the wall." Rockefeller and Ernest F. Hollings "warned that thwarting the merger would damage transatlantic relations and compel retaliatory action by Washington."

President Bush's Assistant Attorney General for Antitrust, Charles A. James, voiced his criticism of the EU's GE/Honeywell decision in a series of speeches. ${ }^{470}$ Immediately after the decision, James stated that "[c]lear and longstanding U.S. antitrust policy holds that the antitrust laws protect competition, not competitors," and that this EU decision represented a "significant point of divergence." another speech in which he criticized the so-called "portfolio effects" analysis employed by the EU as "antithetical to the goals of antitrust law enforcement." ${ }^{972}$ Deputy Assistant Attorney General for the Antitrust Division William Kolasky reiterated those views in a November 2001 speech. ${ }^{473}$ Kolasky again criticized the "portfolio effects" approach of the EU and also chastised it for focusing on the mixed bundling theory as a means of coming to its decision. ${ }^{474}$

The Bush Administration also criticized the EU and Korean Microsoft decisions. Shortly after the EU's imposition of sanctions, Senate Majority Leader Bill Frist condemned the Commission's action. Claiming that Europe's economies were stagnant because of huge debt, taxes, and crippling business regulation in Brussels, Mr. Frist stated that the "European Commission has taken aim at Microsoft, a company whose products and technology have been engines of global economic growth."475

${ }^{468}$ Edmund L. Andrews \& Paul Meller, Europe Ends Bid by G.E. for Honeywell, N.Y. TIMES, July 4,2001 , at $\mathrm{C} 1$

469 William Drozdiak, European Union Kills GE Deal, WASH. POST (July 4, 2001), https://www.washingtonpost.com/archive/politics/2001/07/04/european-union-kills-ge-deal/6df4380ad272-4642-aced-1 cf53fbb9c87/?noredirect=on\&utm term=.46d644cba9a9.

${ }^{470}$ Charles A. James, Assistant Attorney Gen., Antitrust Div., International Antitrust in the 21st Century, Address Before the OECD Global Forum on Competition 4-5 (Oct. 17, 2001), http:/www.oecd.org/daf/competition/prosecutionandlawenforcement/2438935.pdf.

${ }^{471}$ Press Release, U.S. Dep't of Justice, Statement by Assistant Attorney General Charles A. James on the EU's Decision Regarding the GE/Honeywell Acquisition (July 3, 2001), https://www.justice.gov/archive/atr/public/press_releases/2001/8510.pdf.

${ }^{472}$ Charles A. James, Assistant Attorney Gen., Antitrust Div., International Antitrust in the Bush Administration, Address Before the Canadian Bar Association (Sept. 21, 2001), https://www.justice.gov/att/speech/international-antitrust-bush-administration.

${ }^{473}$ William J. Kolasky, Deputy Assistant Attorney Gen., Antitrust Div., Conglomerate Mergers and Range Effects: It's a Long Way from Chicago to Brussels, Address Before the George Mason University Symposium (Nov. 9, 2001), https://www.justice.gov/atr/speech/conglomerate-mergers-and-rangeeffects-its-long-way-chicago-brussels.

${ }^{474} \mathrm{Id}$.

${ }^{475}$ James Kanter, Don Clark \& John R. Wilke, EU Imposes Sanctions on Microsoft; Fine, Disclosure Penalties Aim to Undercut Dominance; Continued Pressure Signaled, WALL ST. J., Mar. 25, 2004 , at A2. 
R. Hewitt Pate, then head of the Antitrust Division, said the Commission's demand that a Windows version be offered without the media player went too far and expressed concerns that "imposing code removal remedies" could potentially produce unintended consequences down the road. He also reiterated Charles James's argument from the GE/Honeywell case by mentioning that "sound antitrust policy must avoid chilling innovation and competition even by dominant companies."

President Obama was equally critical of the European Commission's investigation of Google's alleged policy of "favoring its search results over those of competitors." ${ }^{477}$ His primary criticism of the European Union's decision was that the EU was motivated in this decision by the commercial interests of its tech companies who struggle to compete with larger American rivals, such as Google. ${ }^{478} \mathrm{He}$ claimed that the EU was "hiding protectionism behind a veil of principle" and suggested that the true blame in this difference in policy lies within protectionist European firms and governments because they cannot possibly compete fairly against the United States. ${ }^{479}$

The Ireland/Apple state aid deal dispute arose at the end of the Obama Administration and continues to play a role in the Trump Administration's policy decisions. The United States Treasury Department said that this punishment jeopardized "the important spirit of economic partnership between the U.S. and the E.U." ${ }^{480}$ Chuck Schumer called it a "cheap money grab" by the European Commission that targeted U.S. businesses and the U.S. tax base. ${ }^{481}$ The Trump Administration responded by unsuccessfully seeking to intervene in Apple's appeal of the Commission's order. ${ }^{482}$ Other recent EU state aid tax investigations include Amazon, McDonald's, Starbucks, and Google and are bound to generate similar controversy. ${ }^{483}$

\footnotetext{
${ }^{476} \mathrm{Id}$.

${ }^{477}$ Todd C. Frankel, In E.U. Antitrust Suit, Google Is Up Against 'a Tough Cookie', WASH. PosT (Apr. 15, 2015), https://www.washingtonpost.com/business/economy/google-faces-antitrust-chargesby-european-regulators/2015/04/15/c3845b46-e31a-1 le4-81ea-0649268f729e_story.html.

${ }^{478}$ Henry Farrell, Obama Says That Europeans Are Using Privacy Rules to Protect Their Firms Against U.S. Competition. Is He Right?, WASH. POST (Feb. 17, 2015), https:/www.washingtonpost.com/news/monkey-cage/wp/2015/02/17/obama-says-that-europeans-areusing-privacy-rules-to-protect-their-firms-against-u-s-competition-is-he-right/.

${ }^{479} \mathrm{Id}$.

${ }^{480}$ James Kanter \& Mark Scott, Deal for Apple on Irish Taxes Is Ruled Illegal, N.Y. TIMES, Aug. 31,2016 , at A1.

${ }^{481} \mathrm{Id}$.

${ }^{482}$ Roger Fingas, Court Rejects US Bid to Intervene in Apple's Appeal of EU Tax Ruling, APPLE INSIDER (Dec. 15, 2017), https://appleinsider.com/articles/17/12/15/court-rejects-us-bid-to-intervene-inapples-appeal-of-eu-tax-ruling.

${ }^{483}$ European Commission Press Release IP/17/3701, State Aid: Commission Finds Luxembourg Gave Illegal Tax Benefits to Amazon Worth Around €250 Million (Oct. 4, 2017), http://europa.eu/rapid/press-release_IP-17-3701_en.htm.
} 
Most recently, President Trump tweeted his displeasure at the EU's five billion dollar fine of Google in connection with its Android licensing practices. ${ }^{484}$ Undoubtedly, more tweets and more traditional and diplomatic criticisms will unfold as Google and other U.S. corporations continue to draw enforcement actions and penalties for conduct that the United States chooses not to challenge or treats more leniently.

\section{Exclusion from the Conversation}

There is a robust and ongoing conversation among governments and non-governmental experts about competition law, policy, institutions, remedies, and norms. That conversation takes place in international organizations, bilateral consultations, cooperation between agencies on individual enforcement matters, technical assistance with newer and smaller competition agencies, bar associations, industry groups, universities, think tanks, conferences, legal publications, and in legal, business, and general interest publications. ${ }^{485}$

The United States is, and should be, part of that conversation. We have a proud history and a record of great accomplishment. However, the rest of the world is less subject to U.S. pressure and less interested in U.S. recommendations that are rooted in the history and present policies of the United States if these ideas do not meet the needs of the other jurisdictions. At the same time, the rest of the world has an increasingly deep and impressive track record of enforcement, as well as legal and policy innovations of their own. If the antitrust community is going to continue to have a productive dialogue and not a series of one-way speeches, then a number of changes must occur. These changes include a recognition of difference, a greater appreciation for listening, the need for two-way learning, a recognition of the limits of deep harmonization, and a fundamentally different role for the United States on the international stage.

\section{Look Before You Leap}

For decades, the United States has been a vigorous salesman for the principles embodied in the Sherman Act. ${ }^{486}$ It is not clear how successful it has been of late. It is also not clear why most jurisdictions should adopt a particular position or practice of the United States in their own competition law without great care and caution. The slow, complicated adoption of criminal cartel enforcement in certain jurisdictions (and rejection in others) illustrates the need to tailor concepts appropriate to one legal culture before implementation in another setting.

484 Donald J. Trump (@realDonaldTrump), TwitTER (July 19, 2018, 9:11 AM), https://twitter.com/realDonaldTrump/status/1019932691339399168

${ }^{485}$ Spencer Weber Waller, Antitrust and Democracy, 46 FLA. ST. U. L. REV. 807, 848-53 (2019).

${ }^{486}$ Spencer Weber Waller, Neo-Realism and the International Harmonization of Law: Lessons from Antitrust, 42 U. KAN. L. REV. 557, 569-71 (1994). 


\section{Avoid Bullying}

There is a significant difference between not understanding how the United States approaches a particular competition issue and fully understanding what is being advocated, but not agreeing with the proposal. The knowledge and sophistication of enforcers, practitioners, and academics around the world suggest that the latter is the case far more than the former. As Oliver Wendell Holmes once observed: "[Y]ou can not argue a man into liking a glass of beer." 487

The United States has made its case forcefully and often to the international antitrust community. It should continue to do so when it believes that the national interest so dictates. But decades into the international antitrust game, the world is now pretty much divided into those who like the U.S. beer and those who do not.

There is a different model that derives from the field of community organizing of social work. In past decades, well-meaning community organizers were often the voice of oppressed or powerless communities, teaching them what they needed and how to get it. In more recent times, a newer model has emerged where the goal is not to be the voice for another community but to support them in finding their voice and be an ally as they advocate on their own behalf. ${ }^{488}$

\section{Learn to Listen}

Perhaps it is time for the United States in the international antitrust arena to "talk less, smile more." community organizing, we are at, or rapidly arriving at, the point in global antitrust discourse where the United States should advocate less for what it wants and listen more to the hopes and needs of other jurisdictions and how to help them achieve their own goals.

There is still an important role for the United States (and other developed jurisdictions) to play in providing technical assistance and other forms of training to the smaller, newer, and poorer antitrust jurisdictions around the

\footnotetext{
${ }^{487}$ Oliver Wendell Holmes, Natural Law, 32 HARV. L. REV. 40, 41 (1919).

${ }^{488}$ See, e.g., Dave Beckwith \& Cristina Lopez, Community Organizing: People Power from the Grassroots, COMM-ORG, http://comm-org.wisc.edu/papers97/beckwith.htm (last visited Nov. 30, 2019) (describing how community organizers work with volunteers to develop the "mechanism for the group to advocate on their own behalf"); Peter Levine, Barack Obama on Community Organizing (1988), PETER LEVINE: A BLOG FOR CIVIC RENEWAL (Mar. 6, 2012), http:/peterlevine.ws/?p=8293 (describing Barack Obama's view that community organizing can reveal and leverage assets within the community); Mike Miller, Alinsky for the Left: The Politics of Community Organizing, Dissent (2010), https://www.dissentmagazine.org/article/alinsky-for-the-left-the-politics-of-community-organizing (describing how community organizers work with community members to develop the leadership skills and abilities needed to effect change); The Democratic Promise: Saul Alinsky \& His Legacy, ITVS, https://itvs.org/films/democratic-promise (last visited Nov. 30, 2019) (a documentary on community organizer Saul Alinsky and "people's organizations").

${ }^{489}$ Lin-Manuel Miranda, Aaron Burr, Sir, in HAMILTON: AN AMERICAN MusiCAL (2015) (quoting Aaron Burr in the Broadway musical about Alexander Hamilton).
} 
world. These jurisdictions seek to enforce their laws often with minimal resources and experience. Bilateral, regional, and international fora can be a vital tool for workshops on how to do the work of competition enforcement better. But better often means actively listening to determine the needs of beneficiaries and helping them find their voice, not echoing the voice of another.

\section{Listen to Learn}

It may also be time for the United States to consider being a buyer, rather than seller, in the arena of antitrust policy. It has been decades since the United States was the world's policeman for antitrust. For better or worse, that honor now goes to the EU for the foreseeable future if the hands-off attitude of the United States toward the issue of single firm conduct continues.

Is there really nothing the United States can learn from the more than sixty years of EU competition law, or the nearly thirty years since the flowering of global antitrust regimes in the wake of the fall of the Soviet Union? One starting point may be the value of applying competition law to restraints in the public sector or involving firms receiving special privileges from the state. Anticompetitive state and local restrictions may be less of an issue in the United States compared to countries with a history of socialism or state-planned economies, but it is not a negligible problem. It is also one which unusually tends to unite antitrust conservatives and liberals as an issue worth tackling.

It would probably take congressional action to overturn the antitrust state action doctrine as enunciated by the Supreme Court in Parker v. Brown and its progeny. ${ }^{490}$ There also is uncharted territory involving the interpretation of sovereign immunity under the Eleventh Amendment as another possible source of state authority to impede competition. ${ }^{491}$

The FTC has begun down this path without expressly relying on the many sources of comparative competition law to support its efforts to narrow the state action doctrine. It has brought selected antitrust enforcement actions which have resulted in the Supreme Court raising the bar for successful invocation of state action immunity. ${ }^{492}$ At the same time, it has also resulted in certain state legislatures more explicitly mandating the anticompetitive results and processes to satisfy the new Supreme Court standards, making it hard to determine the net results in the real world. ${ }^{493}$

${ }^{490}$ Parker v. Brown, 317 U.S. 341, 350-51 (1943)

${ }^{491}$ Susan Beth Farmer, Altering the Balance Between State Sovereignty and Competition: The Impact of Seminole Tribe on the Antitrust State Action Immunity Doctrine, 23 OHIO N.U. L. REV. 1403, 1404 (1997)

${ }^{492}$ N.C. Bd. of Dental Exam'rs v. FTC, 135 S. Ct. 1101, 1110-11 (2015).

${ }^{493}$ Lisa Schencker, FTC Drops Challenge of West Virginia Hospital Merger, MOD. HEALTHCARE (July 6, 2016, 1:00 AM), http://www.modernhealthcare.com/article/20160706/NEWS/160709960. 
For the past several years, the FTC has also begun an "economic liberty" project as a competition advocate for the removal of state and local restraints on competition that harm consumers even if protected by the state action doctrine as currently understood. ${ }^{494}$

Perhaps it is time to use the collective experience of the rest of the world as an additional argument for the benefits of this approach. The United States is not the only federal system in the world to confront the issue of the limits of the authority of constituent states or provinces. The United States has never highly valued comparative law in the competition sphere, or in general. Perhaps now is the time to employ this new type of learning and argumentation in both its litigation and advocacy strategies to diminish harm to competition from an entire sector of the economy only partially subject to the normal rules of the competitive market.

Even if the U.S. agencies are not receptive to the explicit reference to comparative competition norms, the courts may be another fertile arena for learning from international practice. It is highly unusual for any U.S. court or agency to cite foreign law or practice in the antitrust field except as background information to deciding an issue on purely U.S. grounds. ${ }^{495}$ This was once a necessity as the United States was nearly alone in having a mature body of antitrust learning and precedent. It is no longer the case. The divergence and diversity of doctrine and practice set forth in this Article provide many fertile avenues for consideration in improving our own laws, procedures, institutions, and remedies. Learning and best practices should be a two-way street and a true form of regulatory humility in moving toward best practices based on a body of global experience where the United States is often the outlier.

\section{Be Aware of New Rhetorical Strategies}

Rhetoric, discourse, and language are important tools to channel conversation, close off paths for discussions, categorize contending points

\footnotetext{
${ }^{495}$ This is true more generally and is part of a broader debate about the proper role of comparative and foreign law, which is beyond the scope of this Article. See STEPHEN BREYER, THE COURT AND THE WORLD: AMERICAN LAW AND tHE NeW Global ReAlities 236-37, 239 (2015) (discussing and responding to the argument that U.S. courts should not cross-reference foreign cases).
}

${ }^{494}$ Economic Liberty, FED. TRADE COMMISSION, https://www.ftc.gov/policy/advocacy/economicliberty 
of view as beyond the pale, and define the shape of disciplines. ${ }^{496}$ They can be both tools of reaction and revolution. ${ }^{497}$

United States officials and commentators are employing a variety of relatively new rhetorical strategies in response to new movements in U.S. antitrust and the continuing developments on the international and global front. Many of these strategies seem innocuous or even self-evident. Many of these suggestions even contain important kernels of truth.

At the same time, most of these strategies represent an attempt to maintain the primacy of a normative and theoretical position about how to operate the antitrust enterprise and an attempt to justify the relative inaction of the United States in enforcing types of causes of action that are commonplace in other jurisdictions. It will be interesting to follow how the continuing international dialogue between the United States and the rest of the world embraces or rejects some of the rhetorical justifications of the U.S. status quo.

\section{i. Hipster Antitrust}

Figures from former U.S. Senator Orrin Hatch to former FTC Commissioner Joshua Wright have derided hipster antitrust as anything that argues against increased economic concentration and its effects on employment, wages, technological progress, abuse of power, and other societal ills. ${ }^{498}$ It is not clear exactly what hipster antitrust is or whether it is a bad thing. In general, a hipster can be defined "as a person who follows the latest trends and fashions, especially those regarded as being outside the cultural mainstream.

${ }^{496}$ See Michel Foucault, POWER/KNOWLEDGE: SELECTED INTERVIEWS AND OTHER WRITINGS 1972-1977, at 131, 133 (Colin Gordon ed., Colin Gordon et al. trans., 1980) (discussing how each society has its own "general politics" of truth-"the types of discourse which it accepts and makes function as true"); Ludwig WitTgenstein, Philosophical Investigations 11-15 (G.E.M. Anscombe trans., Macmillan Co. 1958) (1953) (exploring role of language games); Annabelle Lukin, The Paradox of Noam Chomsky on Language and Power, CONversation (Nov. 13, 2011, 10:34 PM), http://theconversation.com/the-paradox-of-noam-chomsky-on-language-and-power-4174 (describing Chomsky's argument that discourse is a mechanism for managing public opinion).

497 See Peter Berger \& Thomas luckmann, The Social Construction of Reality: A TREATISE IN THE SOCIOLOGY OF KNOWLEDGE 117-18 (1966) (describing how theories of legitimation can be used to justify both continuation and change in the status quo); THOMAS S. KUHN, THE STRUCTURE OF SCIENTIFIC REVOLUTIONS 5-7 (1962) (describing how scientific research takes place within the context of existing theory and how scientific revolution requires the reevaluation of prior theories and facts).

${ }^{498}$ See, e.g., David Dayen, Orrin Hatch, the Original Antitrust Hipster, Turns on His Own Kind, INTERCEPT (Aug. 7, 2017, 3:03 PM), https://theintercept.com/2017/08/07/orrin-hatch-the-originalantitrust-hipster-turns-on-his-own-kind/ (describing Senator Hatch's use of the term to describe critics of the use of the consumer welfare standard in determining questions of anticompetitive mergers and industries)

${ }^{499}$ Hipster, LEXICO, https://www.lexico.com/en/definition/hipster (last visited Aug. 27, 2019). 
Hipster can also mean artisanal, custom, uniquely created products and services for discerning customers. That suggests the antitrust enterprise is not one size fits all and should be crafted with the needs of the customer in mind, rather than the purveyor.

This intended epithet is invoked primarily to denigrate anything and anyone that criticizes the wealth maximization paradigm favored by Robert Bork and his disciples ${ }^{500}$ More polite discourse on these topics tends to characterize critics of Borkian antitrust as neo-Brandeisians, but still dismisses such concerns as either unworkable in practice or beyond the proper boundaries of antitrust. ${ }^{501}$ Either way, dismissing fundamental critiques of one view of the work of antitrust, primarily associated with the United States, misses the current state of the world, which approaches competition law and policy with a broader palate of tools and approaches.

\section{ii. Evidence-Based Antitrust}

A somewhat similar group of commentators argues in favor of evidencebased antitrust. ${ }^{502}$ At the most banal level, it is hard to argue with the need

\footnotetext{
500 See John Newman, Anti-Hipster Antitrust,
https://papers.ssrn.com/sol3/papers.cfm?abstract_id $=3454807$; Dayen, supra note 498 (discussing Bork's support of the consumer welfare standard, which permits mergers as long as companies argue that the merger will result in lower prices).

501 Although beyond the scope of this Article, the Brandeisian concern with the economic and political influence of powerful firms has been a persistent influence in U.S. law for over a century and a concern for those focusing on the effects of corporate power on democracy. K. SABEEL RAHMAN, DEMOCRACY AgAINST DOMINATION 1-2, 4 (2017); Harry First \& Spencer Weber Waller, Antitrust's Democracy Deficit, 81 FordHAM L. REV. 2543, 2573 (2013).

502 See Joshua D. Wright, Abandoning Antitrust's Chicago Obsession: The Case for EvidenceBased Antitrust, 78 ANTITRUST L.J. 241, 242-43 (2012) (describing "evidence-based antitrust" as a commitment to "testing economic theories with economic knowledge" and to using empirical data to support these theories); Interview with Joshua D. Wright, Commissioner, Federal Trade Commission, ANTITRUST SOURCE, Aug. 2014, at https://www.americanbar.org/content/dam/aba/publishing/antitrust_source/aug14_wright_intrvw_7_23f .authcheckdam.pdf (describing evidence-based antitrust as an approach using the best economic theory and evidence to make critical enforcement, policy, and agency design decisions); Makan Delrahim, Assistant Attorney Gen., U.S. Dep't of Justice, Keynote Address at the University of Chicago's Antitrust and Competition Conference (Apr. 19, 2018), https://www.justice.gov/opa/speech/assistant-attorneygeneral-makan-delrahim-delivers-keynote-address-university-chicagos (describing "evidence-based enforcement" as a component of an antitrust consensus); Joshua D. Wright, Comm'r, Fed. Trade Comm'n, Remarks at the Competition Law Center: Evidence-Based Antitrust in the Technology Sector 1-2 (Feb. 23, 2013) (defining "evidence-based antitrust" as the "common-sense dictum" that antitrust enforcement should be based on "sound economic and empirical foundations"), https://www.ftc.gov/sites/default/files/documents/public_statements/evidence-based-antitrustenforcement-technology-sector/130223chinaevidence.pdf; Maureen K. Ohlhausen, Acting Chairman, Fed. Trade Comm'n, The FTC's Path Ahead, Remarks at the GCR Live 6th Annual Antitrust Law $\begin{array}{lllll}\text { Leaders } & \text { Forum } & 8 & \text { (Feb. 2017), }\end{array}$ https:/www.ftc.gov/system/files/documents/public_statements/1070123/gcr_the-ftc_path_ahead.pdf (describing how a "devotion to empiricism" informs her view of antitrust); Maureen K. Ohlhausen, Comm'r, Fed. Trade Comm'n, Antitrust Policy for a New Administration 2 (Jan. 24, 2017), https://www.ftc.gov/system/files/documents/public_statements/1051993/antitrust_policy_for_a_new_a
} 
for evidence that supports the allegations underlying an investigation or decision. But when one drills down below the surface, this rhetorical ploy is another way of preferring inaction to action. Such a view favors avoiding type I errors versus type II errors, assumes markets will self-correct quickly, and promotes the view that any form of enforcement risks making things worse rather than better. ${ }^{503}$

Scratch a little deeper and the ideological roots of these arguments become more apparent. For some critics, there is simply never enough evidence to support a past, present, or future enforcement action. For others, a strong commitment to Borkian antitrust theory results in the preferencing of one type of evidence over others, or the dismissal of record evidence of competitive harm when not in line with a theoretical commitment. The rhetoric of evidence-based antitrust masks a set of positions and arguments that may or may not represent the present or future of U.S. antitrust. It is aimed primarily at domestic consumption and ill-suited for other jurisdictions with a very different past and present for competition law and policy.

\section{iii. Regulatory Humility}

Former FTC chair Maureen Olhausen, among others, has argued for "regulatory humility" as a guide star for competition policy. ${ }^{504}$ Again, on the surface, this seems both sensible and innocuous. No one wants a bureaucrat or agency with an enormous ego acting out with a vengeance. However, scratching even the surface of such rhetoric reveals a similar policy preference for inaction, lack of regulation, reliance on markets, and various policy positions that are laissez faire in nature, but largely unrelated to humility in any normal sense of the word. It is not a humility born out of a need to faithfully execute a mission set by the legislature. It is not a humility

dministration.pdf (stating that former FTC Commissioner Ohlhausen favors evidence-based solutions); Maureen K. Ohlhausen, Comm'r, Fed. Trade Comm'n, Statement of Commissioner Maureen K. $\begin{array}{llll}\text { Ohlhausen } & 1 & \text { (Jan. } & 13,\end{array}$ https://www.ftc.gov/system/files/documents/public_statements/1049793/mkohlhausen_statement_ip_g uidelines.pdf (arguing for an evidence-based approach to intellectual property rights).

${ }^{503}$ See Frank H. Easterbrook, The Limits of Antitrust, 63 TEX. L. REV. 1, 3-4 (1984) (arguing that antitrust enforcement actions have sacrificed efficiency at times and increased prices).

${ }_{504}$ Joshua D. Wright, Revisiting Antitrust Institutions: The Case for Guidelines to Recalibrate the Federal Trade Commission's Section 5 Unfair Methods of Competition Authority, ConCURRENCES: COMPETITION L.J., 2013, at 3-4, https://www.ftc.gov/sites/default/files/documents/public_statements/siting-antitrust-institutions-caseguidelines-recalibrate-federal-trade-commissions-section-5-unfair/concurrences-4-2013 pdf (calling for the FTC to adjust its Unfair Methods of Competition authority based on "regulatory humility"); Maureen K. Ohlhausen, 100 is the New 30: Recommendations for the FTC's Next 100 Years, 21 GEO. MASON L. REV. 1131, 1138 (2014) (calling for the FTC to exercise "regulatory humility" to avoid reducing incentives for business innovation); Maureen K. Ohlhausen, Comm'r, Fed. Trade Comm'n, Regulatory $\begin{array}{llllll}\text { Humility in } & \text { Practice } & \text { (Apr. } & 1,\end{array}$ https://www.ftc.gov/system/files/documents/public_statements/635811/150401aeihumilitypractice.pdf. 
born out of a desire to respect precedent. It is not a humility born out of a need to match policy preferences to the evidence in a case.

Humility by agencies or courts is thus orthogonal to the policy preferences of whether to open an investigation, initiate a proceeding, or reach a decision. It is not a sign of humility to reverse (or continue) the policies of a prior administration; it is a sign of belief in the correctness of one's position on the merits of the issue. It is hardly convincing to similarly situated enforcers outside of the body politic, who view enforcement of the law as set forth in their system as their humble duty.

\section{iv. Due Process and Procedural Fairness}

The most sympathetic arguments of the new rhetoric of U.S. antitrust is the need for greater due process and procedural fairness. ${ }^{505}$ Due process is a hallmark of procedural democracy enshrined in the constitutions, treaties, regulations, and administrative laws of most jurisdictions. Enforcement, inaction, or a decision based on corruption, favoritism, or discrimination is an anathema to justice. By themselves, calls for greater transparency and due process are hard to argue with in the abstract. The ICN has adopted twelve general principles for procedural fairness in antitrust matters. ${ }^{506}$ At the same time, the United States is leading the charge to negotiate a broader and more precise global framework covering most of the world's competition jurisdictions. ${ }^{507}$

Concerns remain that these talks are aimed at strengthening the hand of the U.S. government when U.S. firms are subject to foreign proceedings. ${ }^{508}$ It will be interesting to observe how these tools will be used when there are decisions against U.S. firms as either plaintiffs or defendants in mature democratic foreign regimes and when U.S. agencies and courts render antitrust decisions affecting foreign firms as either plaintiffs or defendants. The line between procedure and substance often can be hard to discern.

505 Introduction to ANTITRUST ProcedURAL FAIRNESS 1, 1-2 (D. Daniel Sokol \& Andrew T. Guzman eds., 2019).

${ }^{506}$ ICN Guiding Principles for Procedural Fairness in Competition Agency Enforcement, INT'L COMPETITION NETWORK, http://icn2018delhi.in/images/AEWG-Guiding-Principles-4PF.pdf (last visited Aug. 29, 2019); see generally Chris Townley, Mariana Tavares \& Mattia Guidi, Influence in the International Competition Network (ICN): Who Seeks It, How Do They Do This and Why? 4 (unpublished manuscript), https://papers.ssrn.com/sol3/papers.cfm?abstract_id=3415067 (describing the International Competition Network's work to propose "superior standards and procedures in competition policy").

${ }^{507}$ Press Release, U.S. Dep't of Justice, New Multilateral Framework on Procedures Approved by the International Competition Network (Apr. 5, 2019), https://www.justice.gov/opa/pr/new-multilateralframework-procedures-approved-international-competition-network.

508 Victoria Graham, Global Antitrust Standards Talks Continue Despite Trade Conflict, BLOOMBERG L. NEWS, July 11, 2018 (Remarks of Stephen Calkins). 


\section{CONCLUSION}

This has been an article about difference rather than the wisdom of the choices made. Competition law outside the United States is well developed, but very different in many respects. Competition law as a field is defined by a common set of concerns at the highest level of generalities that agreements between undertakings (particularly cartels) pose a risk of harming competition, that the behavior of dominant firms can be a concern, and that certain mergers and acquisitions can harm competition. Scratch below that surface and a growing series of divergences quickly appears. Many do not affect how a particular case comes out in a particular jurisdiction or how jurisdictions can profitably cooperate with each other without contention to do their jobs better.

Regardless of what goals or outcomes one favors for antitrust law and policy in the United States, this Article argues that the U.S. system is fundamentally different from its international counterparts. In some ways, those differences are as stark as the day and night worlds of The Omega Man's world, even if they are less dramatic.

In a fundamental way, we are dealing with two different worldviews about the realities of a global economy. For better or worse, the U.S. system is litigation driven before juries and generalist judges. It is heavily invested in criminal enforcement and contains multiple centers of federal, state, and private enforcement. The U.S. system is more concerned about overenforcement rather than underenforcement and operates with a far smaller toolkit than many of its global counterparts. Outside the United States, competition law more often has a broader vision and toolkit for what is deemed within the purview of competition policy. International competition law is increasingly focused on scrutinizing tech giants and is centered in unitary competition agencies. It is administrative in nature, with large fines as the principal enforcement tool, and is less bound up in the rhetoric of overenforcement. It is subject to deferential judicial review and has only embryonic private enforcement.

These two ways of looking at the world of competition law and policy largely co-exist, but occasionally conflict. The dream of deep substantive harmonization appears to be receding, rather than advancing, despite the commendable work of organizations like the International Competition Network, the Organisation for Economic Co-operation and Development, and the United Nations Conference on Trade and Development. But the enduring differences go beyond substantive doctrine and include procedure, institutions, remedies, ideologies, and the very boundaries of the purview of antitrust and competition.

History, culture, ideology, and even inertia suggest that these are two fundamentally different ways of approaching an important issue of international economic law that is unlikely to change anytime soon. There may not be many active day-to-day conflicts between such differing views, 
but there will be conflicting burdens on private parties, increased costs of navigating different systems, and specific disagreements that generate much heat and light.

It is fair to discuss and debate whether a given law, procedure, institution, or remedy can be improved, but there are no universal solutions for all but the most mundane issues. The United States is not as isolated as Robert Neville in The Omega Man, but it is still an outlier. Whether in terms of population or GDP, the vast majority of the rest of the world has competition law. It just isn't ours. We may be an early adopter of competition law, but we are not alone. We are legend. 